Universidade de São Paulo

Instituto Oceanográfico

\title{
Dinâmica bacteriana em sedimentos costeiros de Ubatuba, São Paulo
}

Paula Carpintero de Moraes

Dissertação apresentada ao Instituto Oceanográfico da Universidade de São Paulo, como parte dos requisitos para obtenção do título de Mestre em Ciências, área de Oceanografia Biológica.

Julgada em

Prof(a). Dr(a).

Conceito

Prof(a). Dr(a).

Conceito

Prof(a). Dr(a).

Conceito 
“Aos meus queridos pais Paulo Afonso e Maria Otília e ao meu amor Eduardo, vocês são a luz da minha vida." 
"O esforço é grande e o homem é pequeno.

Eu, Diogo Cão, navegador, deixei

Este padrão ao pé do areal moreno

$\mathcal{E}$ para diante naveguei.

A alma é divina e a obra é imperfeita.

Este padrão sinala ao vento e aos céus

Que, da obra ousada, é minha a parte feita:

O por fazer é só com Deus.

E ao imenso e possível oceano

Ensinam estas Quinas, que aqui vês,

Que o mar com fim será grego ou romano:

O mar sem fim é português.

E a Cruz ao alto diz que o que me há na alma E faz a febre em mim de navegar

Só encontrará de Deus na eterna calma

O porto sempre por achar."

Fernando Pessoa. 
SUMÁRIO

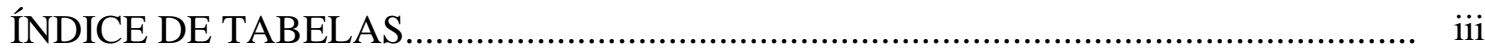

ÍNDICE DE FIGURAS..............................................................................

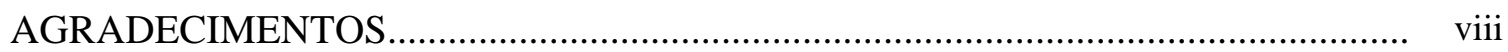

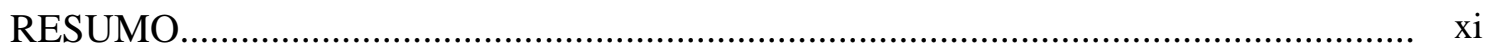

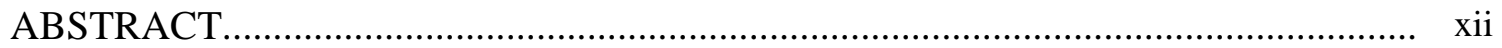

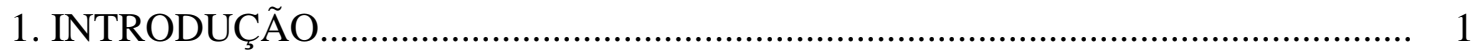

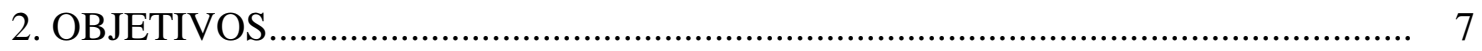

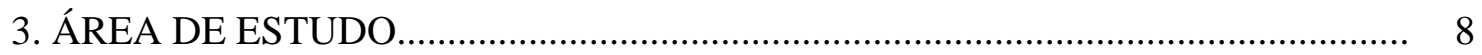

4. MATERIAIS E MÉTODOS............................................................................. 10

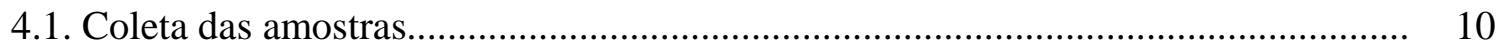

4.2. Análise granulométrica...................................................................................... 12

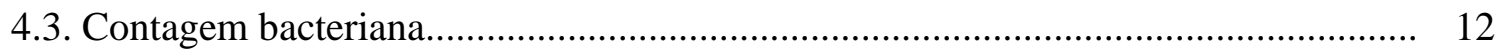

4.4. Normalizações............................................................................................. 15

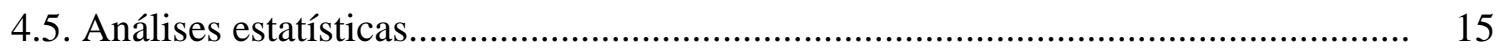

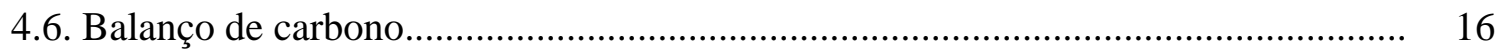

5. RESULTADOS

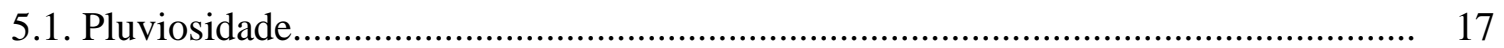

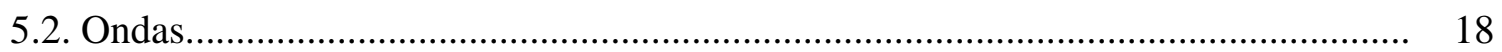

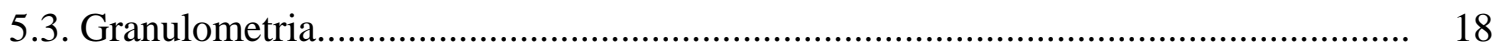

5.4. Distribuição espaço-temporal da comunidade bacteriana.......................................... 21

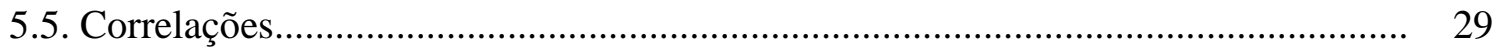


5.6. Análises de componentes principais (ACP).......................................................... 38

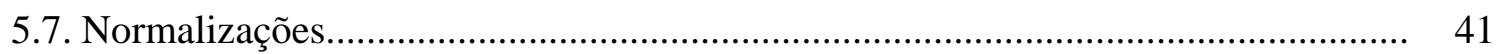

5.8. Balanço de carbono orgânico nas comunidades microbianas.................................. 44

5.9. Distribuição vertical da comunidade bacteriana....................................................... 49

6. DISCUSSÃO

6.1. Variação espacial da comunidade bacteriana............................................................ 56

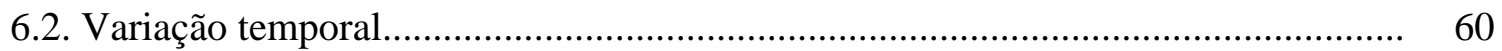

6.3. Principais influências na variação da comunidade bacteriana.................................. 64

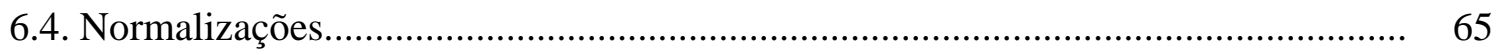

6.5. Balanço de COT nas comunidades microbianas..................................................... 67

6.6. Distribuição da comunidade bacteriana na coluna sedimentar................................. 69

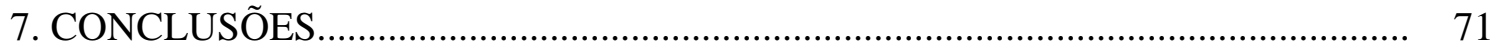

8. CONSIDERAÇÕES FINAIS E PERSPECTIVAS FUTURAS ................................. 72

9. REFERÊNCIAS BIBLIOGRÁFICAS.................................................................. 74 


\section{ÍNDICE DE TABELAS}

Tabela 1: Posição geográfica das estações, profundidade e equipamentos utilizados nos períodos de coleta do projeto.

Tabela 2: Resultados das análises granulométricas em cada estrato do sedimento $(1=$ 0-2 cm, $2=2-5 \mathrm{~cm}$ e $3=5-10 \mathrm{~cm}$ ), nas enseadas de Fortaleza (estação 1 a 4 ) e Ubatuba (estação 5 a 8). ar = areia, $\mathrm{s}=$ silte, ar.s. = areia síltica, s.ar. = silte arenoso, s.ag. = silte argiloso, ar.ag. = areia argilosa, s.ag.ar. = silte argilo arenoso e gran. = grânulo.....

Tabela 3: Resultados estatísticos do teste ANOVA ou Kruskal-Wallis entre valores médios de densidade bacteriana nos meses de coleta em cada estação $(p<0,05)$. ns: valores do testes não apresentaram diferenças significativas $(\mathrm{p}>0,05)$......

Tabela 4: Resultados estatísticos do teste ANOVA ou Kruskal-Wallis entre valores médios de biomassa bacteriana nos meses de coleta em cada estação $(p<0,05)$. ns: valores do testes não apresentaram diferenças significativas $(p>0,05)$......

Tabela 5: Resultados estatísticos do teste ANOVA ou Kruskal-Wallis entre valores médios de densidade e biomassa bacteriana entre as estações em cada mês de coleta $(p<0,05)$. ns: valores do testes não apresentaram diferenças significativas $(p>0,05) \ldots . . .$.

Tabela 6: Resultados estatísticos do teste ANOVA ou Kruskal-Wallis entre valores médios de densidade e biomassa bacteriana entre as estações de cada enseada em cada mês de coleta $(\mathrm{p}<0,05)$. ns: valores do testes não apresentaram diferenças significativas $(\mathrm{p}>0,05)$......

Tabela 7: Dados referentes à temperatura de fundo e porcentagem de sedimentos finos nas estações e meses de coleta. s.d.: sem dados.

Tabela 8: Resultados estatísticos do teste de correlação de Pearson referentes aos valores de densidade e biomassa bacteriana em relação aos dados complementares bióticos e abióticos $(n=24)$. T.F.: temperatura da água de fundo. Valores de $\mathrm{r}_{\text {(Pearson) }}$ em negrito apresentaram correlação significativa $(p<0,05)$.

Tabela 9: Resultados estatísticos do teste de correlação de Pearson referentes aos valores de densidade e biomassa bacterianas em relação aos dados complementares bióticos e abióticos ( $\mathrm{n}=12)$, em cada enseada analisada separadamente. T.F.: temperatura da água de fundo. Valores de $\mathrm{r}_{\text {(Pearson) }}$ em negrito apresentaram correlação significativa $(\mathrm{p}<0,05)$..

Tabela 10: Resultados estatísticos do teste de correlação de Pearson dos valores de densidade e biomassa bacterianas em relação aos dados complementares bióticos referentes aos valores da camada superficial da coluna sedimentar $(0-2 \mathrm{~cm})$ (dados normalizados para COT) e a temperatura de fundo (T.F.) $(n=24)$. Valores de $\mathrm{r}_{\text {(Perarson) }}$ em negrito obtiveram correlação significativa $(p<0,05)$.. 
Tabela 11: Resultados estatísticos do teste de correlação de Pearson dos valores de densidade e biomassa bacterianas em relação aos dados complementares bióticos referentes aos valores da camada superficial da coluna sedimentar $(0-2 \mathrm{~cm})$ (dados normalizados para COT) e a temperatura de fundo (T.F.) (n=12), em cada enseada separadamente. Valores de $\mathrm{r}_{\text {(Perarson) }}$ em negrito obtiveram correlação significativa $(\mathrm{p}<0,05)$

Tabela 12: Razão clorofila-a/feopigmento da coluna sedimentar $(10 \mathrm{~cm})$ de cada estação de coleta em cada mês de estudo, e valores de razão $\mathrm{C} / \mathrm{N}$ da camada superficial $(0-2 \mathrm{~cm})$ da coluna sedimentar em cada estação e mês de coleta....................

Tabela 13: Porcentagem de contribuição de CO pela comunidade microbiana (ATP), produtores primários (clorofila-a) e biomassa bacteriana para o pool de COT em cada estação e mês de coleta. Todos os valores usados em $\mu \mathrm{g}$ C / g sedimento seco....

Tabela 14: Resultados estatísticos do teste ANOVA $(\mathrm{p}<0,05)$ referentes aos valores de densidade e biomassa bacterianas nos estratos do sedimento, em cada estação e mês de coleta. ns: valores do testes não apresentaram diferenças significativas ( $\mathrm{p}>0,05)$ 


\section{ÍNDICE DE FIGURAS}

Figura 1: Distribuição idealizada dos perfis verticais dos compostos oxidados (aceptores de elétrons) no sedimento marinho. Fonte: Kristensen (2000).

Figura 2: Mapa da área de estudo (litoral norte de São Paulo, Ubatuba), com a localização dos pontos de coleta. Os números indicam as estações de coleta: 1, 2, 3, e 4 na Enseada da Fortaleza e 5, 6, 7 e 8 na Enseada de Ubatuba.

Figura 3: Bactérias vistas ao microscópio de epifluorescência, objetiva de 100X............

Figura 4: Pluviosidade da região de Ubatuba durante o período de coletas de amostras. Fonte: Estação Meteorológica da Base Norte do Instituto Oceanográfico da USP.....

Figura 5: Altura e direção de ondas da região de Ubatuba durante o período de coleta das amostras (período medido em dias de dezembro de 2004 a novembro de 2005)........

Figura 6: Porcentagens médias dos valores de cada tipo morfológico de bactéria encontradas em cada estação de coleta durante todo o período amostral..........................

Figura 7: Porcentagens médias dos valores de bactéria livre e aderida ao detrito encontradas em cada estação de coleta durante o período amostral

Figura 8: Variação temporal dos valores médios integrados de densidade bacteriana das estações de coleta nas Enseadas de Fortaleza e Ubatuba. Barras verticais indicam o erro padrão.

Figura 9: Variação temporal dos valores médios integrados de biomassa bacteriana nas estações de coleta nas Enseadas de Fortaleza e Ubatuba. Barras verticais indicam o erro padrão.

Figura 10: Variação temporal dos valores médios integrados de porcentagem de células em divisão nas estações de coleta nas Enseadas de Fortaleza e Ubatuba (linhas verticais indicam erro padrão).

Figura 11: Valores médios integrados dos dados bióticos (MOT, clorofila-a, feopigmentos e ATP), da Enseada de Fortaleza (Estação 1 a 4) nos meses de coleta, barras verticais indicam o erro padrão. Fonte: Laboratório de Dinâmica Bêntica/IOUSP.

Figura 12: Valores médios integrados dos dados bióticos (MOT, clorofila-a, feopigmentos e ATP), da Enseada de Ubatuba (Estação 6 a 7) nos meses de coleta, barras verticais indicam o erro padrão. Fonte: Laboratório de Dinâmica Bêntica/IOUSP. 
Figura 13: Dados bióticos (densidade bacteriana, MOT, clorofila-a, feopigmentos e ATP, normalizados para COT), da camada superficial do sedimento $(0-2 \mathrm{~cm})$ da Enseada de Fortaleza (Estação 1 a 4) nos meses de coleta.

Figura 14: Dados bióticos (densidade bacteriana, MOT, clorofila-a, feopigmentos e ATP, normalizados para COT), da camada superficial do sedimento $(0-2 \mathrm{~cm}) \mathrm{da}$ Enseada de Ubatuba (Estação 5 a 8) nos meses de coleta.

Figura 15: Valores da densidade bacteriana, e biomarcadores lipídicos referentes a produtores primários (AGP), bactéria (AGR) e plantas terrestres (AGCL) e referentes a fontes variadas (AGCC) em cada estação de coleta, no estrato de $0-2 \mathrm{~cm}$, no verão (fevereiro). Fonte dos dados de lipídios: Laboratório de Dinâmica Bêntica/IOUSP.

Figura 16: Valores integrados de densidade bacteriana, meiofauna e macrofauna encontrados em cada estação nos meses de coleta. Fonte dos valores de meio- e macrofauna: C.O. Quintana, comunicação pessoal.

Figura 17: Resultado gráfico da ACP das estações de coleta em cada mês (scores) em relação às variáveis medidas. F1 a $4=$ enseada de Fortaleza; U5 a $8=$ enseada de Ubatuba; D = dezembro/2004; F = fevereiro/2005; A = abril/2005; J = junho/2005; Ag = agosto/2005; $\mathrm{N}=$ novembro/2005. Três principais grupos formados: $\mathrm{A}, \mathrm{B}, \mathrm{C} . . . . . . . . . . . . .$.

Figura 18: Resultado gráfico da ACP para estações de coleta em cada mês (scores) na enseada de Fortaleza em relação às variáveis medidas. $\mathrm{D}=$ dezembro/2004; $\mathrm{F}=$ fevereiro/2005; $\mathrm{A}=$ abril/2005; $\mathrm{J}=$ junho/2005; $\mathrm{Ag}=$ agosto/2005; $\mathrm{N}=$ novembro/2005. Três principais grupos formados: A, B, C.

Figura 19: Resultado gráfico da ACP para os inventários da coluna sedimentar nas estações de coleta em cada mês (scores) na enseada de Ubatuba em relação às variáveis medidas. $\mathrm{D}=$ dezembro/2004; $\mathrm{F}=$ fevereiro/2005; $\mathrm{A}=$ abril $/ 2005 ; \mathrm{J}=$ junho/2005; $\mathrm{Ag}=$ agosto/2005; $\mathrm{N}=$ novembro/2005. Dois principais grupos formados: A e B.

Figura 20: Resultados de densidade (esquerda) e biomassa (direita) bacterianas normalizados para g sedimento seco, conteúdo de água e porosidade referentes a dezembro/2004, nas estações de coleta (linhas verticais indicam o erro padrão).

Figura 21: Resultados de densidade (esquerda) e biomassa (direita) bacterianas normalizados para g sedimento seco, conteúdo de água e porosidade referentes a fevereiro de 2005, nas estações de coleta (linhas verticais indicam o erro padrão).

Figura 22: Resultados de densidade (esquerda) e biomassa (direita) bacterianas normalizados para g sedimento seco, conteúdo de água e porosidade referentes a abril de 2005, nas estações de coleta (linhas verticais indicam o erro padrão). 
Figura 23: Resultados de densidade (esquerda) e biomassa (direita) bacterianas normalizados para g sedimento seco, conteúdo de água e porosidade referentes a junho de 2005, nas estações de coleta (linhas verticais indicam o erro padrão)

Figura 24: Resultados de densidade (esquerda) e biomassa (direita) bacterianas normalizados para g sedimento seco, conteúdo de água e porosidade referentes a agosto de 2005, nas estações de coleta (linhas verticais indicam o erro padrão)....

Figura 25: Resultados de densidade (esquerda) e biomassa (direita) bacterianas normalizados para g sedimento seco, conteúdo de água e porosidade referentes a novembro de /2005, nas estações de coleta (linhas verticais indicam o erro padrão).......

Figura 26: Esquema ilustrativo dos pools relativos às comunidades microbianas em cada estação e mês de coleta. Foram utilizados valores médios da camada superficial do sedimento $(0-2 \mathrm{~cm})$ dos valores de biomassa baseados no ATP, em clorofila-a e biomassa bacteriana (Figuras em escala).

Figura 27: Porcentagem de biomassa bacteriana relativa à biomassa microbiana nas estações em cada mês de coleta (St 1 a 4 enseada de Fortaleza e St 5 a 8 enseada de Ubatuba)

Figura 28: Perfil vertical dos valores de densidade bacteriana na Fortaleza nos meses de coleta. Barras horizontais indicam o erro padrão

Figura 29: Perfil vertical dos valores de densidade bacteriana em Ubatuba nos meses de coleta. Barras horizontais indicam o erro padrão

Figura 30: Perfil vertical dos valores de biomassa bacteriana na Fortaleza nos meses de coleta. Barras horizontais indicam o erro padrão.

Figura 31: Perfil vertical dos valores de biomassa bacteriana em Ubatuba nos meses de coleta. Barras horizontais indicam o erro padrão.

Figura 32: Perfil vertical das porcentagens médias de células em divisão na enseada de Fortaleza nos meses estudados. Barras horizontais indicam o erro padrão.

Figura 33: Perfil vertical das porcentagens médias de células em divisão na enseada de Ubatuba nos meses estudados. Barras horizontais indicam o erro padrão. 
AGRADECIMENTOS

Primeiramente, gostaria de agradecer ao Instituto Oceanográfico da Vniversidade de São Paulo (IOUSP) e ao Programa de Pós-graduação em Oceanografia Biológica por ter propiciado a realização deste estudo. À Fundação de Amparo a Pesquisa do Estado de São Paulo (FAPESP) pela bolsa de mestrado disponibilizado para a elaboração desta dissertação de mestrado e pelo financiamento do projeto.

Meus sinceros agradecimentos ao Prof. Dr. Paulo Yukio Gomes Sumida, pela orientação e pelos ensinamentos nestes três anos de trabalho, por ter me iniciado no mundo da oceanografia e pela paciência $e$ amizade demonstrada nestes anos. Muito abrigada por todas as puxadas de orelha e pela alegria demonstrada em todas as horas de trabalho, e principalmente por ter acreditado em mim e no meu trabalho.

Agradeço muito a toda minha família. Aos meus pais Paulo e Lote, que são as pessoas mais importantes da minha vida, obrigada pela atenção, apoio e por acreditarem e terem tanto orgulho do que eu faço. Eu amo muito vocês e sem o seu apoio eu nunca teria conseguido, desculpa se sou uma filha desnaturada, mas vocês me conhecem eu puxei a vocês. Minhas queridas irmãs Alessandra e Fernanda que de forma bem diferente me apoiaram e ajudaram em todas as horas dificeis e pelas noites deliciosas de conversa e de festas. Leca muito obrigado por ser esta segunda mãe que sempre foi e por cuidar de mim sempre mesmo estando longe e por me dar este monte de coisas que é característico da pessoa maravilhosa que você é. Aos meus avós Therezinha e Zé por me apoiarem e por estarem sempre do meu lado. Vovoca valeu pelos seus dotes artísticos e por fazer sempre tudo pra me ver feliz te amo muito!!!!!!!

Eduardo, como começar a te agradecer. Você sabe que eu te amo muito, você é meu melhor amigo e há muitos anos você me apóia em tudo o que eu faço e se desvira para não deixar eu me abalar. Muito obrigada por ter acreditado no meu sonho e por ter vindo comigo para São Paulo sem nunca reclamar, sem nunca perder seu 6om humor. Obrigada por ter me tolerado principalmente nas horas do meu mau humor e meus ataques de raiva que sempre desconto em você, mas você nunca, nunca deixou te abalar e sempre com 6om humor levantava meu astral. Esta dissertação é metade sua também, você passou comigo por todos os processos de todas as formas possiveis. Muito obrigada por seu amor e compreensão, sua ajuda é muito importante para mim. Te amo!

Aos meus grandes amigos Adriana e Eduardo eu agradeço a compreensão e peço mil desculpas por ter sumido em uma hora que vocês precisavam de mim. Sei que tenho sido muito ausente neste último ano, mas prometo que vou mudar isso e quero que saibam que amo muito vocês e que eu não esqueci não. 
Obrigada pela amizade de vocês e por estes longos anos em que saímos juntos e nos divertimos muito. Dri você sabe que amiga igual você não se acha em lugar nenhum eu tenho muito orgulho de ter sua amizade te amo amiga.

Aos meus amigos distantes Glé e Li, adoro vocês e espero que a gente se encontre mais nos próximos anos estou com saudades, vocês foram muito importantes na minha formação muito obrigada pelo apoio e compreensão. Serginho e Joel valeu pela amizade e pela alegria que sempre trazem quando vem nos visitar em Sampa, vocês estão devendo viu. Gica Longi, valeu por tudo.

Ao André, muito obrigada pela amizade e alegria, por ser uma pessoa maravilhosa e ter convivido com a gente estes anos.

À minha grande amiga Cintia pela amizade e pelos seus ensinamentos. Cabeça valeu por estes anos de muita alegria, pelas longas discussões e pela sua paciência, por ter me ensinado a mexer em todos os programas e por ter me ajudado em todas as horas dificeis tanto profissionais quanto pessoais. Você foi minha primeira amiga dentro do IO e espero que nossa amizade continue também fora dele, muito obrigada pela sua paciência e por estar sempre ali quando precisei, nem preciso falar que não teria conseguido sem você. $\mathcal{E}$ claro o mais importante obrigada pelas viagens e festas que fizemos juntas, sempre divertidas e maravifhosas. Te adoro!!!!!!!!

Ao Marcos por ser quase um segundo orientador. Valeu muito cabeção pelas puxadas de orelha e pelo incentivo, pelos milhares de artigos e discussões, pelas correções e enfim por tudo. Agradeço também pela amizade e pela paciência que você teve comigo, pelas longas conversas não só sobre trabalho, mas sobre a vida de "cientista". Muito obrigada cabeção!

A todos os amigos do laboratório de Dinâmica Bêntica que tornam os dias de trabalho muito prazerosos. Andréa pela sua grande alegria e amizade, valeu por agüentar minhas crises chatas e pelas caronas para a FAPESP e claro pelas bebedeiras, você é uma pessoa maravilhosa que sempre consegue levantar meu astral, valeu muito amiga. Ao Leo valeu por tudo, pela estadia no Rio pela amizade e conhecimento, valeu por ser uma pessoa maravilhosa e por estar sempre disposto a ajudar, estou com saudades. Ao Ângelo pela ajuda no inicio do meu trabalho e nas coletas muito divertidas. Betina, Karin e Tutu por todas as conversas e risadas, pelas festas e pela amizade e companheirismo de vocês. Às estagiárias Camila e Maria valeu pela ajuda que sempre deram em todos os trabalhos e por serem pessoas maravilhosas sempre dispostas a ajudar. Todos vocês foram muito importantes.

Aos amigos do IO, Cintia Maria, Cau, Caia, Sandrinha, Mau, Juliano, Bica, Aninha e muitos outros que fizeram destes anos os mais prazerosos possiveis, por todas as festas, conversas, conselhos, caronas, almoços, cafés e muito mais. Muito obrigado pela amizade de vocês e por sempre levantarem meu 
astrale por estarem lá quando precisei, cada um do seu jeito, mas sempre ajudando em tudo. Valeu muito, galera!!!!!. Sansan valeu por sua amizade e ensinamentos, por sua paciência e por me dar vários conselhos, muito obrigada. Natizinha muito obrigada por tudo, pelas caronas incontáveis, por ser muito paciente e pela sua amizade, pelas conversas e pelas ajudas em todas as horas, você é uma pessoa incrível e espero que não nos abandone, tente entender que você já é brasileira e não vamos deixar você partir.

$\mathcal{A}$ todos os funcionários do $\mathscr{D} O B$ que me agüentaram nestes anos. Valter por sempre estar disposto a ajudar em tudo, pelo bom humor e amizade, muito obrigada. D.Cida, Marlene e no início Edna que com muita boa vontade me ajudaram em tudo que precisei muito abrigada pela atenção. Cidinha e Ruth, não tenho nem palavras para agradecer a vocês por terem lavado centenas de potes e frascos sempre com tanta boa vontade, sem vocês meu trabalho seria dobrado muito obrigada pela atenção e ajuda imprescindivel Todo o pessoal da biblioteca agradeço pela atenção e pelas ajudas na busca por artigos e livros. Silvana e Ana Paula por não se importarem em sempre ajudar nas inúmeras dúvidas e atrasos, sem perder o bom humor, mesmo quando deixei vocês falando sozinhas (Foi mau Silvana!!!!!!!!), muito obrigada por tudo, vocês são realmente demais. Ao pessoal do salão azule da oficina por sempre ajudarem em tudo, muito obrigada. Nãa posso esquecer de uma pessoa que me ensinou muita coisa, Martinha valeu pela sua paciência em me ensinar a contar bactérias, pela sua alegria e por me emprestar tudo que precisei, você foi muito importante para que este trabalho fosse possivel.

A todo pessoal da base de V6atu6a, vocês são pessoas maravilhosas ir para V6atuba é sempre uma diversão muito obrigada pela deliciosa comida e pelo clima sempre alegre e descontraído de vocês, por sempre arrumarem um jeitinho pra tudo e sempre ajudarem em tudo que precisei muito obrigada. Aos tripulantes do $B / P q$ Véliger II, pela ajuda nas coletas e por tornar toda saída de barco muito divertida.

Aos professores do IO e de outros institutos que de alguma forma contribuíram para minha formação acadêmica e pessoal através de disciplinas e conversas, muito obrigado pela atenção de vocês.

Agradeço também a todas as pessoas amigas que acabei deixando de fora por simples descuido, (podem me cobrar depois) e que de alguma forma fizeram parte desta fase da minha vida profissionale pessoal. Por fim agradeço a DEUS por ser tão presente em minha vida.

MUITO OBRIGADA A TODOS!!!!!!!!!!!! 


\section{RESUMO}

Sedimentos de regiões costeiras são caracterizados por altas concentrações de matéria de orgânica. As bactérias desempenham um fator chave na decomposição da matéria orgânica e na reciclagem de nutrientes inorgânicos essenciais. Além de representar um dos mais importantes recursos alimentares para a meio- e macrofauna. O presente estudo teve por objetivo avaliar a abundância e biomassa da comunidade bacteriana bêntica de duas enseadas na região costeira de Ubatuba (SP), relacionando-as ao aporte de matéria orgânica de diferentes fontes (marinha, terrestre e antrópica) e à estrutura da comunidade bêntica. Foram realizadas seis coletas bimensais em quatro estações por enseada ao longo de um transecto costa-oceano. O sedimento de cada testemunho foi fatiado a bordo em três camadas (0-2, 2-5 e 5-10 cm). A análise bacteriana foi conduzida através de contagem direta em microscópio de epifluorescência e a atividade através da freqüência de células em divisão. A análise dos parâmetros sedimentares como granulometria, qualidade e quantidade de matéria orgânica, bem como dados de macro e meiofauna foram obtidos através do Projeto DIAGEN, do qual o presente estudo faz parte. Os resultados de densidade e biomassa bacteriana mostraram valores sempre maiores na enseada de Ubatuba em relação à Fortaleza, acompanhado por teores mais elevados de matéria orgânica total, clorofila-a, feopigmentos e biomassa microbiana. O padrão de deposição das enseadas provavelmente teve papel decisivo nos altos valores de biomassa e densidade bacteriana nas regiões centrais e rasas das enseadas. Densidades e biomassas bacterianas mais elevadas foram encontradas no inverno (junho de 2005), não sendo observadas relações direta com os valores de matéria orgânica total ou clorofila-a. O estudo mostrou uma alta atividade bacteriana na camada superficial do sedimento, em especial no outono, com valores sempre maiores na enseada de Fortaleza, contrastando com os valores de densidade e biomassa.

Palavras chaves: bactérias bênticas; áreas costeiras; qualidade da matéria orgânica; enseada de Ubatuba; enseada de Fortaleza 


\begin{abstract}
Coastal sediments are characterized by high organic matter contents. Bacteria play a key role in organic matter decomposition and are essential in the nutrient recycling process. Moreover, represent an important food source for meio- and macrofaunal organisms. The present study aimed to evaluate the abundance and biomass of the benthic bacterial community in two bays of the coastal region of Ubatuba (SP). Bacterial abundance and biomass were compared with the distribution and abundance of different organic matter sources (marine, terrestrial and anthropogenic) and with the structure of the benthic community. We collected samples every two months for a period of one year in four stations on each bay along a coast-ocean transect. Tube cores were used to collect sediment samples, which were sliced on board in three layers (0-2, 2-5 and 5-10 cm). Bacterial abundance and biomass were counted and measured under epifluorescence microscopy and bacterial activity was estimated by the frequency of dividing cells. Information on sediment grain size distribution, quality and quantity of organic matter, as well as macro- and meiofauna were available from Project DIAGEN, from which this study is part. Bacterial density and biomass were always higher in Ubatuba bay, which appeared to be related to larger amounts of total organic matter, chlorophyll-a, pheopigments and microbial biomass. The differential deposition pattern observed in both bays was probably important determining the higher values of bacterial biomass and density found in the central and shallow portions of the bays. Despite higher bacterial density and biomass were found during the winter (June 2004) in most stations, this seemed not to be related to total organic matter or chlorophyll-a. Bacterial activity was high in surficial sediments, especially during autumn, with consistently larger values in Fortaleza bay.
\end{abstract}

Key words: benthic bacteria; coastal sediments; organic matter quality; Ubatuba bay; Fortaleza bay. 


\section{INTRODUÇÃO}

As bactérias constituem um importante compartimento de todos os ecossistemas da Terra, sendo responsáveis pela degradação e reciclagem de elementos essenciais para a vida, como o carbono, nitrogênio e fósforo (Alongi, 1994). A maior parte da atividade destes microorganismos ocorre em solos e sedimentos, simplesmente porque ali estão os maiores depósitos de matéria orgânica.

Os sedimentos marinhos possuem várias propriedades e particularidades físicoquímicas, muitas das quais são de grande importância para a população de microorganismos que ali residem. São sistemas complexos afetados por parâmetros geológicos, hidrodinâmicos, químicos e biológicos, cuja interação caracteriza o ambiente sedimentar de cada região. Em curta escala de tempo, os parâmetros ambientais, tais como, movimento da água, luz, temperatura e nutrientes inorgânicos e orgânicos determinam a estrutura de comunidades microbianas bênticas que, por sua vez, influenciam os padrões diagenéticos da matéria orgânica através do seu metabolismo (Deming \& Barros, 1993).

Os sedimentos marinhos sublitorais estão em contato constante com a água sobrejacente, compartilhando características e nutrientes através de fluxos de água no interior do sedimento. A concentração de oxigênio presente no sedimento é limitada pela sua baixa solubilidade na água intersticial. Desta forma, quando a matéria orgânica está presente, a oxidação aeróbica ocorre em altas taxas na superfície do sedimento, porém, após poucos centímetros de profundidade, sedimentos não perturbados tornam-se quase que universalmente anóxicos (Nealson, 1997). Isto gera uma série de gradientes horizontais estáveis, nos quais vários aceptores de elétrons são consumidos, usualmente na ordem de diminuição do potencial redox (i.e. de acordo com a habilidade de cada aceptor de elétrons de receber elétrons). Abaixo da fina camada óxica superficial, ocorre a chamada zona subóxica, caracterizada por altas concentrações de compostos inorgânicos oxidados (como $\mathrm{Mn}^{4+}, \mathrm{NO}_{3}^{-}$e $\mathrm{Fe}^{3+}$ ). Logo abaixo ocorre a zona reduzida, a qual é caracterizada por compostos de sulfeto produzidos por bactérias redutoras de sulfato (Kristensen, 2000) (Figura 1). 


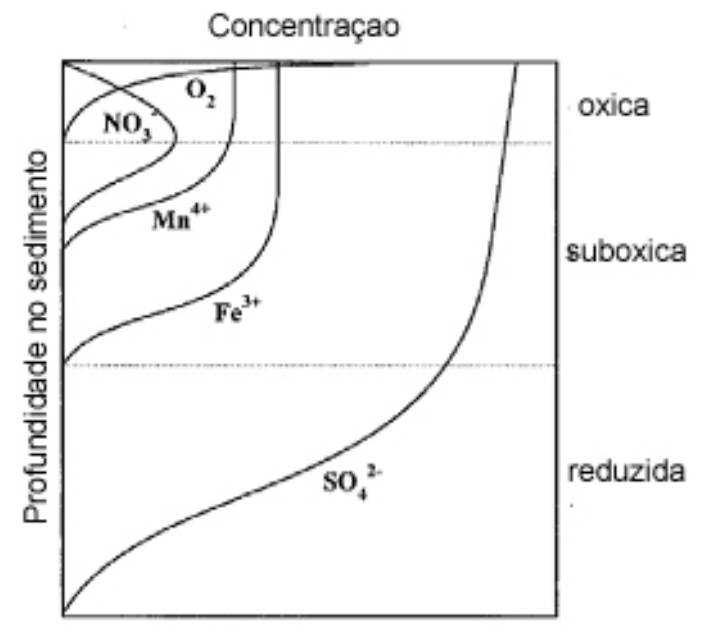

Figura 1: Distribuição idealizada dos perfis verticais dos compostos oxidados (aceptores de elétrons) no sedimento marinho. Fonte: Kristensen (2000).

A ausência de oxigênio na maior parte da coluna sedimentar restringe a vida eucariótica aos primeiros centímetros do sedimento, pois utilizam o oxigênio como único aceptor de elétrons. Em contraste, organismos procarióticos (bactérias) utilizam uma grande variedade de doadores de elétrons, ambos orgânicos e inorgânicos, bem como muitos diferentes aceptores de elétrons na ausência de oxigênio, o que torna esta classe de organismos extremamente versátil na tomada energética (Nealson et al., 1997), tornando estes organismos extremamente numerosos na maioria dos sedimentos marinhos. Além disso, sua biomassa é maior do que a de qualquer outro grupo de organismos bênticos.

Vários processos controlam a degradação da matéria orgânica na camada superficial, tais como os valores nutricionais, a disponibilidade química e física, e o ambiente sobre o qual ela é depositada (temperatura, concentração de oxigênio e de outros aceptores de elétrons) (Canuel \& Martens, 1996). Além disso, bactérias e outros microorganismos são também fundamentais no controle dos processos de ciclagem de elementos químicos (e.g. carbono e nitrogênio) no assoalho marinho, alterando a matéria orgânica e regenerando componentes inorgânicos essenciais (Craven \& Jahnke, 1992). Este processo, somado à atividade dos organismos da macrofauna, controla a profundidade da camada redox, processo acelerado pela catálise bacteriana, bem como, o grau de preservação dos constituintes químicos (Jørgensen, 2000). 
Através das investigações de Dale (1974), o alto número de bactérias em sedimentos marinhos foi quantitativamente documentado. Subseqüentes estudos (MeyerReil et al., 1978; Meyer-Reil, 1980, Meyer-Reil, 1983) demonstraram que as bactérias contribuem significativamente para o carbono orgânico dos sedimentos. Craven \& Jahnke (1992) documentaram uma eficiência de $75-90 \%$ na assimilação de carbono por microorganismos bênticos, os quais representaram cerca de $40 \%$ do carbono orgânico sedimentar. Desta forma, por estarem presentes em grande quantidade, as bactérias contribuem significativamente para o reservatório de carbono vivo dos sedimentos.

Bactérias bênticas também representam um passo-chave na cadeia alimentar bêntica, porque são capazes de explorar inputs orgânicos (Deming \& Barros, 1993) e de aumentar a qualidade da matéria orgânica nos sedimentos através do enriquecimento protéico (Danovaro et al., 1993; Danovaro, 1996). Estudos mostram ainda que bactérias bênticas possuem maior eficiência em explorar a matéria orgânica em ambientes oligotróficos (Danovaro et al., 1999). Desta forma, as bactérias podem representar um dos recursos alimentares utilizados por organismos do meio- e macrobentos (Alongi, 1985; Bouvy, 1988; Arndt, 1991; Sherr \& Sherr, 1994).

Regiões costeiras são conhecidas por suportar uma porção significativa da produtividade primária nos oceanos, porém também podem atuar como recursos ou sumidouros para elementos biogênicos. Sugere-se que a região costeira é responsável por cerca de $20 \%$ da produtividade primária e pela grande maioria do carbono enterrado no oceano (Duarte et al., 2004). Além disso, estudos recentes indicam que a mineralização bêntica em sedimentos costeiros representa cerca de metade do total ocorrendo nos sedimentos marinhos (Midderburg et al., 2004).

Vários tipos de matéria orgânica entram na zona costeira, variando de produtos provenientes da produção primária local por fitoplâncton e/ou por microalgas bênticas a inputs via descarga terrestre e produção proveniente de bancos de macroalgas e fanerógamas marinhas. O recurso de carbono em áreas costeiras é, portanto, caracterizado por uma grande variedade em sua composição e degradabilidade, variando de recursos lábeis tais como fitoplâncton e microalgas bênticas, a recursos menos degradáveis como macrófitas e carbono orgânico de origem terrestre transportado por rios (Bouillon \& Boschker, 2006). 
Em águas rasas, as taxas de deposição do carbono detrítico são altas e a maior parte da decomposição da matéria orgânica ocorre no sedimento (Suess, 1976). A maior porção da matéria orgânica particulada chegando ao assoalho é degradada por bactérias e protozoários (Pfannkuche, 1993), o que demonstra a importância da comunidade bêntica de tamanho pequeno na degradação do carbono (Soltwedel, 1997). As principais reações de diagênese recente resultam da decomposição microbiológica da matéria orgânica e esta atividade produz gradientes complexos no sedimento, que por sua vez afetam a distribuição e atividade metabólica das bactérias (Findlay et al., 1990). A diagênese recente da matéria orgânica em sedimentos marinhos é a combinação de processos biológicos, químicos e físicos que mudam a quantidade e composição da matéria orgânica nas várias centenas de metros superficiais da coluna sedimentar (Henrichs, 1992).

A importância das bactérias nos processos de diagênese recente e seu potencial uso como alimento tem gerado amplo interesse nos processos que afetam as bactérias do sedimento. Fatores relacionados à distribuição e atividade da comunidade microbiana bêntica incluem características físicas, tais como, temperatura e tipo do sedimento (Dale, 1974; DeFlaun \& Mayer, 1983; Albertelli et al., 1992; Köster \& Meyer-Reil, 2001; Köster et al., 2005), características químicas, tal como, a concentração (Delille \& Bouvy, 1989) e composição (Danovaro et al., 1993; Danovaro et al., 1994) da matéria orgânica e processos biológicos, como a predação (Montagna, 1984).

A natureza do substrato (e.g. tamanho de grãos e porosidade) afeta grandemente a colonização bêntica em regiões costeiras (Dale, 1974). Os padrões hidrodinâmicos das áreas costeiras levam à diferenciação entre áreas deposicionais e não-deposicionais. Áreas não-deposicionais apresentam sedimentos com frações grossas, geralmente pobres organicamente devido ao baixo acúmulo de matéria orgânica e menor colonização microbiana (Köster \& Meyer-reil, 2001). Entretanto, apresentam maior influxo advectivo de água intersticial (Huettel \& Gust, 1992), aumentando a camada óxica do sedimento. Atualmente altas taxas de atividade bacteriana e de assimilação de carbono orgânico vêm sendo encontradas nestas regiões (Huettel \& Rusch, 2000; Rusch et al., 2000).

Áreas deposicionais são caracterizadas por altas concentrações de matéria orgânica particulada, fortes gradientes de concentração de nutrientes orgânicos e inorgânicos e elevado fluxo de nutrientes na interface sedimento - água, apresentando altos valores de 
densidade e biomassa bacteriana, principalmente na superfície do sedimento (Köster et al., 2005).

A quantidade e a qualidade da matéria orgânica do sedimento têm sido consideradas como os principais fatores determinantes na estruturação da comunidade microbiana bêntica (Fabiano et al., 1995; Fabiano \& Danovaro, 1998; Witte et al., 2003). Em áreas costeiras, a variabilidade de fontes de carbono faz com que estes ambientes sejam extremamente complexos, com respostas variadas da fauna em função da quantidade e principalmente da qualidade da matéria orgânica sedimentar. Nestas áreas, no entanto, o material terrígeno, que possui compostos altamente refratários, pode representar uma importante fonte de matéria orgânica (Hedges et al., 1997). Entretanto, a maior parte da matéria orgânica lábil provém da produção fitoplanctônica, que pode variar em intensidade sazonal e interanual, afetando a disponibilidade de alimento no sedimento (Sun et al., 1991; Fabiano et al., 1995; Cowan et al., 1996).

Vários estudos realizados com comunidades bacterianas bênticas demonstraram que estas são fortemente influenciadas por variações sazonais de alimento, reagindo quase que imediatamente à chegada de material para o sedimento, após blooms de produção fitoplanctônica, geralmente acompanhando aumentos nos valores de clorofila medidas no sedimento (Meyer-Reil et al., 1978; Meyer-Reil, 1983; Danovaro \& Fabiano, 1995; Danovaro et al., 1999; Danovaro et al., 2000; Pfannkuche et al., 2000; Shiah et al., 2000; Smith et al., 2002; Rusch et al., 2003). Estudos mostram ainda as grandes diferenças espaciais na abundância de bactérias, principalmente relacionadas à presença de certos componentes lábeis na matéria orgânica (e.g. carboidratos e proteínas) (Fabiano \& Danovaro, 1994; Danovaro \& Fabiano, 1995; Relexans et al., 1996; Albertelli et al., 1999; Danovaro et al., 1999), e a uma maior ou menor distância de desembocaduras de rios (Fabiano \& Danovaro, 1995).

A distribuição e composição da comunidade microbiana bêntica parece ser também altamente influenciada pela distribuição e composição da fauna bêntica local. A presença de organismos da macroinfauna, por exemplo, afetam ativamente a natureza física e química dos sedimentos (Findlay et al., 1990). Estruturas macrofaunais, tais como buracos formados por animais construtores de tubos, representam um importante mosaico de microambientes físico-químicos e biológicos na maioria dos ambientes costeiros 
(Kristensen, 2000). A renovação da água nos tubos construídos pela macrofauna e os processos de irrigação são importantes fatores controlando os processos microbianos no sedimento. $\mathrm{O}$ aumento na troca de solutos entre os sedimentos e a água aumenta o suprimento de aceptores de elétrons dissolvidos, altera a distribuição das reações microbianas e diminui o efeito potencialmente inibidor de certos produtos metabólicos (Kristensen \& Kostka, 2004). Em geral, a macrofauna aumenta o metabolismo microbiano bêntico e a capacidade de decomposição da matéria orgânica através de seus efeitos no transporte de solutos e partículas (Aller, 2001; Kristensen \& Kostka, 2004). No entanto, este efeito estimulante depende de fatores-chave como, por exemplo, a densidade, mobilidade, tamanho e tipo de alimentação da fauna, assim como quantidade e qualidade da matéria orgânica (Papaspyrou et al., 2004).

A ação de predação bacteriana tem sido documentada nas diversas classes de animais bênticos, macro- meio- e microbentos (Kemp, 1990). Animais macrobênticos não parecem consumir uma quantidade significante da produção bacteriana. Na verdade, os principais consumidores de bactérias bênticas parecem ser os metazoários menores, como organismos da meiofauna (dominados por nemátodes e copépodes) e protozoários (dominados por flagelados e ciliados) (Epstein \& Shiaris, 1992).

No Brasil, estudos com comunidades bacterianas bênticas ainda não são muito numerosos. Estudos bacterianos em coluna de água foram realizados na região de Cananéia (SP) (Watanabe, 1980; Mesquita \& Peres, 1985) e Ubatuba (SP) (Mesquita, 1993). Na região de Ubatuba (SP), área de estudo do presente projeto, nenhum estudo anterior sobre bactérias do sedimento foi realizado. A maior parte dos estudos realizados nesta região descreve a estrutura e dinâmica dos organismos metazoários da meiofauna (Curvelo, 2003), macrofauna (Muniz et al., 2000) e megafauna (Sumida \& Pires-Vanin, 1997). Métodos que estimam a biomassa microbiana através de ATP particulado também foram conduzidos (Quintana, 2004; Sumida et al., 2005; Yoshinaga et al., 2006), porém estes não distinguem as classes microbianas, realizando apenas uma medida geral de biomassa (Karl \& Novitsky, 1988).

A região de Ubatuba, Estado de São Paulo, possui um grande número de enseadas, o que favorece o acúmulo de matéria orgânica em ambientes rasos. A grande variedade de fontes disponíveis de matéria orgânica na região, tanto marinha como 
terrestre, ou natural versus antrópica, certamente influenciam a abundância de bactérias nos sedimentos. Além disso, a produtividade primária na região é essencialmente sazonal em função da penetração da Água Central do Atlântico Sul (ACAS) e da ocorrência de chuvas e frentes frias (Aidar et al., 1993; Gaeta et al., 1995). Desta forma, considerando o importante papel das bactérias na decomposição e remineralização da matéria orgânica sedimentar, bem como na estruturação da cadeia trófica bêntica, o presente estudo contribui de forma inédita e imprescindível para o entendimento das transformações de matéria orgânica e da dinâmica da fauna bêntica na região de Ubatuba.

O presente trabalho está inserido no projeto "Indicadores moleculares da qualidade da matéria orgânica em sedimentos costeiros: diagênese recente e influência no sistema bêntico em Ubatuba-SP (DIAGEN)", que visou estudar a origem, qualidade e quantidade de matéria orgânica particulada (MOP) em nível molecular e a diagênese recente no ecossistema costeiro raso de Ubatuba. Para tanto, a quantificação da abundância de bactérias é de fundamental importância, já que as bactérias constituem elementos decisivos na ciclagem de material orgânico no ambiente marinho.

\section{OBJETIVO}

O presente trabalho teve como objetivo a avaliação da variação da densidade, biomassa e atividade da comunidade bacteriana bêntica em duas enseadas na região de Ubatuba (SP), espacialmente em cada enseada (em um gradiente costa-oceano) e entre as enseadas, e sazonalmente (nas quatro estações do ano), em resposta à chegada de diferentes quantidades e qualidades de matéria orgânica, relacionando esta resposta a outros padrões das comunidades metazoárias bênticas do local.

O objetivo específico do trabalho centrou-se em responder as seguintes hipóteses:

1. A Enseada de Ubatuba apresenta maiores valores de densidade e biomassa bacteriana, devido a maior aporte de matéria orgânica terrestre e antrópica, porém ambas enseadas apresentam um padrão similar de distribuição em um gradiente costa-oceano; 
2. Os maiores valores de abundância e biomassa bacteriana ocorrem na camada superficial do sedimento diminuindo com o aumento da profundidade da coluna sedimentar;

3. A abundância e biomassa da comunidade bacteriana bêntica varia em fase com a quantidade e qualidade da matéria orgânica lábil presente no sedimento;

\section{3. ÁREA DE ESTUDO}

O estudo foi realizado em duas enseadas, Fortaleza e Ubatuba, na região de Ubatuba, costa norte do estado de São Paulo (Figura 1). Esta extensão do litoral paulista caracteriza-se pela presença marcante da Serra do Mar, que se projeta diretamente sobre o oceano formando planícies costeiras bastantes restritas e limitando o sistema de drenagem continental. A região é caracterizada por um regime oligo- a mesotrófico, sendo a produtividade primária marinha limitada pela escassez de nutrientes inorgânicos, em parte devido a baixa contribuição terrestre (Braga \& Muller, 1998). A produtividade primária da região é dominada por espécies do nanoplâncton, mesmo nas épocas de maiores produtividades, quando blooms esporádicos de diatomáceas podem ocorrer (Sassi \& Kutner, 1982; Gaeta et al., 1999).

No verão, a influência dominante na produtividade primária é associada à predominância de ventos paralelos à costa e ao aumento no regime de chuvas e tempestades. Durante os períodos de primavera-verão há na costa uma predominância de ventos E-NE, que induzem um transporte da Água Costeira (AC, localizada nas proximidades da costa) em direção ao oceano, o que é compensado pela entrada da Água Central do Atlântico Sul (ACAS) na camada subsuperficial, formando uma termoclina sazonal (Castro-Filho et al., 1987). A presença da ACAS, uma massa d'água fria e rica em nutrientes, sobre o domínio interno da plataforma continental (10 a $50 \mathrm{~m}$ de profundidade), promove incremento de nutrientes na zona eufótica, ocorrendo blooms esporádicos de organismos planctônicos e o incremento da produção nova na região (Pires-Vanin \& Matsuura, 1993; Gaeta et al., 1995; Rocha et al., 2003). O aumento da ocorrência de chuvas e tempestades características da estação promove maior input de matéria suspensa, sedimento e matéria orgânica de origem continental, que também contribuem para o 
aumento da produtividade da região durante meses de primavera-verão (Mahiques, 1995; Gaeta et al., 1999).

No outono-inverno, os ventos SW (atribuídos às frentes frias) causam um empilhamento da Água Tropical (AT) em direção à costa e um recuo da ACAS em direção à quebra da plataforma. Este padrão, juntamente com o esfriamento das águas superficiais e a intensificação de misturas devido aos ventos fortes, torna as águas próximas à costa quase homogêneas, havendo uma maior interação de AT e AC (Castro-Filho et al., 1987). O aumento de frentes frias e homogeneidade da coluna de água durante esta época do ano tornam a ressuspensão e regeneração de nutrientes os principais fatores dirigindo a produtividade primária na região (Sassi \& Kutner, 1982).

A circulação observada na região permite supor a existência de um fluxo no sentido horário permanente em ambas as enseadas, levando a maiores deposições nas regiões centrais (Mahiques, 1995). A diferença entre as enseadas, quanto a interação da direção de ondas e a extensão e orientação da boca das enseadas, assim como o número e tamanho dos corpos de água terrestres, leva a sensíveis variações na dinâmica de cada enseada.

A enseada de Ubatuba possui desembocadura voltada para leste e apresenta um grande estrangulamento, induzindo a difração de ondas vindas de sul e sudeste (Mahiques, 1995). A característica hidrodinâmica da enseada promove uma maior quantidade de sedimentos finos nas porções internas e centrais das enseadas, onde ocorre uma grande acumulação da matéria orgânica tanto de origem marinha como terrestre e antrópica (Mahiques et al., 1998). Três rios principais (Rio da Lagoa, Rio Grande de Ubatuba e Rio Acaraú) influenciam esta enseada, especialmente com o aumento no fluxo de material terrestre durante o verão, influenciando a qualidade da água devido ao aumento do input de esgoto não tratado proveniente da cidade de Ubatuba (Burone, 2002; Muniz et al., 2006).

A enseada de Fortaleza possui a desembocadura larga e voltada para S-SE, estando sujeita à forte ação de ondas provenientes de tempestades na sua desembocadura. É caracterizada por uma distribuição mais homogênea das frações sedimentares, geralmente com baixa razão silte/argila, e por menores concentrações de matéria orgânica, ainda acumulando-se nas regiões centrais da enseada. Apenas um rio principal (Rio Escuro) está presente e a enseada apresenta uma maior contribuição de material de origem marinha 
(Mahiques et al., 1998). O despejo de esgoto sanitário de populações caiçaras, de veraneio e da ocupação turística está presente, porém em menor escala quando comparada àquela da Enseada de Ubatuba.

\section{MATERIAL E MÉTODOS}

\subsection{Coleta das amostras}

As coletas foram realizadas em 8 estações na região de Ubatuba (SP), sendo 4 na Enseada de Fortaleza e 4 na Enseada de Ubatuba, em seis coletas sazonais, em dezembro de 2004 (primavera/verão), fevereiro de 2005 (verão), abril de 2005 (outono), junho de 2005 (outono/inverno), agosto de 2005 (inverno) e novembro (primavera) (Tabela 1) a bordo do $\mathrm{B} / \mathrm{Pq}$ Véliger II. As estações foram realizadas em profundidades crescentes, num transecto cortando a porção central de cada enseada (Figura 2).

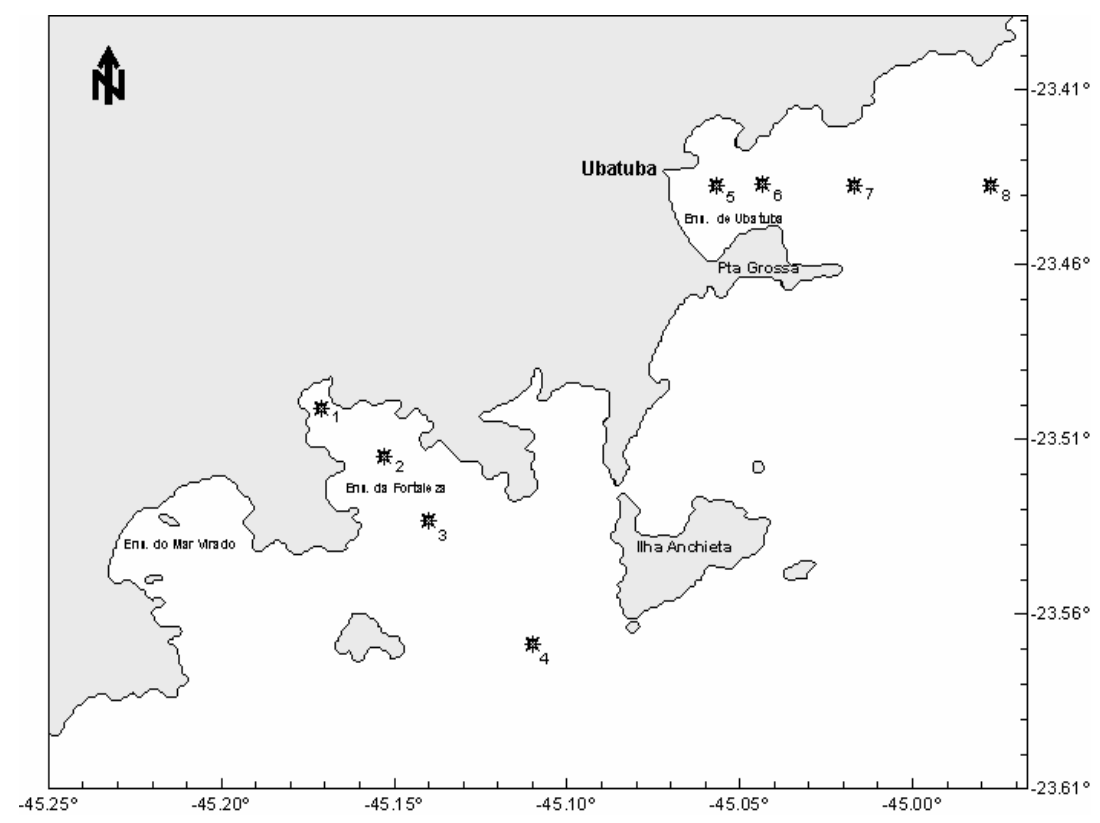

Figura 2: Mapa da área de estudo (litoral norte de São Paulo, Ubatuba), com a localização dos pontos de coleta. Os números indicam as estações de coleta: 1, 2, 3, e 4 na Enseada da Fortaleza e 5, 6, 7 e 8 na Enseada de Ubatuba. 
Tabela 1: Posição geográfica das estações, profundidade e equipamentos utilizados nos períodos de coleta do projeto.

\begin{tabular}{|c|c|c|c|c|}
\hline Estação & Posição & Profundidade (m) & Data & Equipamento de coleta \\
\hline 1 & $23^{\circ} 30,076^{\prime} \mathrm{S} 45^{\circ} 10,255^{\prime} \mathrm{W}$ & 4 & $8 / 12 / 2004$ & mergulho autônomo e mini-multicorer \\
\hline 2 & $23^{\circ} 30,903^{\prime} \mathrm{S} 45^{\circ} 09,274^{\prime} \mathrm{W}$ & 8,8 & $8 / 12 / 2004$ & mergulho autônomo e mini-multicorer \\
\hline 3 & $23^{\circ} 31,981^{\prime} \mathrm{S} 45^{\circ} 08,388^{\prime} \mathrm{W}$ & 11 & $8 / 12 / 2004$ & mini-multicorer \\
\hline 4 & $23^{\circ} 34,105^{\prime} \mathrm{S} 46^{\circ} 06,601^{\prime} \mathrm{W}$ & 17,7 & $8 / 12 / 2004$ & mini-multicorer \\
\hline 5 & $23^{\circ} 26,239^{\prime} \mathrm{S} 45^{\circ} 03,396^{\prime} \mathrm{W}$ & 5 & $7 / 12 / 2004$ & mergulho autônomo e mini-multicorer \\
\hline 6 & $23^{\circ} 26,189^{\prime} \mathrm{S} 45^{\circ} 02,6^{\prime} \mathrm{W}$ & 9 & $7 / 12 / 2004$ & mergulho autônomo e mini-multicorer \\
\hline 7 & $23^{\circ} 26,243^{\prime} \mathrm{S} 45^{\circ} 01,004^{\prime}$ & 13 & $7 / 12 / 2004$ & mini-multicorer \\
\hline 8 & $23^{\circ} 26,234^{\prime} \mathrm{S} 44^{\circ} 58,648^{\prime} \mathrm{W}$ & 19 & $6 / 12 / 2004$ & mini-multicorer \\
\hline 1 & $23^{\circ} 30,063^{\prime} \mathrm{S} 45^{\circ} 10,262^{\prime} \mathrm{W}$ & 4 & $23 / 02 / 2005$ & mergulho autônomo e mini-multicorer \\
\hline 2 & $23^{\circ} 30,913^{\prime} \mathrm{S} 45^{\circ} 09,274^{\prime} \mathrm{W}$ & 8 & $23 / 02 / 2005$ & mergulho autônomo e mini-multicorer \\
\hline 3 & $23^{\circ} 31,971^{\prime} \mathrm{S} 45^{\circ} 08,400^{\prime} \mathrm{W}$ & 11 & $23 / 02 / 2005$ & mergulho autônomo e mini-multicorer \\
\hline 4 & $23^{\circ} 34,101^{\prime} \mathrm{S} 45^{\circ} 06,585^{\prime} \mathrm{W}$ & 17 & $23 / 02 / 2005$ & mini-multicorer \\
\hline 5 & $23^{\circ} 26,249^{\prime} \mathrm{S} 45^{\circ} 03,408^{\prime} \mathrm{W}$ & 5,3 & $22 / 02 / 2005$ & mergulho autônomo e mini-multicorer \\
\hline 6 & $23^{\circ} 26,189^{\prime} \mathrm{S} 45^{\circ} 02,623^{\prime} \mathrm{W}$ & 8,8 & $22 / 02 / 2005$ & mini-multicorer \\
\hline 7 & $23^{\circ} 26,241^{\prime} \mathrm{S} 45^{\circ} 01,001^{\prime} \mathrm{W}$ & 13 & $22 / 02 / 2005$ & mini-multicorer \\
\hline 8 & $23^{\circ} 26,249^{\prime} \mathrm{S} 44^{\circ} 58,636^{\prime} \mathrm{W}$ & 18 & $22 / 02 / 2005$ & mini-multicorer \\
\hline 1 & $23^{\circ} 30,082^{\prime} \mathrm{S} 45^{\circ} 10,266^{\prime} \mathrm{W}$ & 4 & $19 / 04 / 2005$ & mini-multicorer \\
\hline 2 & $23^{\circ} 30,900^{\prime} \mathrm{S} 45^{\circ} 09,271^{\prime} \mathrm{W}$ & 8,5 & $19 / 04 / 2005$ & mini-multicorer \\
\hline 3 & $23^{\circ} 31,975^{\prime} \mathrm{S} 45^{\circ} 08,386^{\prime} \mathrm{W}$ & 11 & $19 / 04 / 2005$ & mini-multicorer \\
\hline 4 & $23^{\circ} 34,108^{\prime} \mathrm{S} 45^{\circ} 06,600^{\prime} \mathrm{W}$ & 17,5 & $19 / 04 / 2005$ & mini-multicorer \\
\hline 5 & $23^{\circ} 26,248^{\prime} \mathrm{S} 45^{\circ} 03,393^{\prime} \mathrm{W}$ & 5 & $18 / 04 / 2005$ & mini-multicorer \\
\hline 6 & $23^{\circ} 26,217^{\prime} \mathrm{S} 45^{\circ} 02,603^{\prime} \mathrm{W}$ & 9 & $18 / 04 / 2005$ & mini-multicorer \\
\hline 7 & $23^{\circ} 26,240^{\prime} \mathrm{S} 45^{\circ} 01,004^{\prime} \mathrm{W}$ & 12,5 & $18 / 04 / 2005$ & mini-multicorer \\
\hline 8 & $23^{\circ} 26,261^{\prime} \mathrm{S} 44^{\circ} 58,656^{\prime} \mathrm{W}$ & 18,6 & $18 / 04 / 2005$ & mini-multicorer \\
\hline 1 & $23^{\circ} 30,069^{\prime} \mathrm{S} 45^{\circ} 10,254^{\prime} \mathrm{W}$ & 4,3 & $29 / 06 / 2005$ & mini-multicorer \\
\hline 2 & $23^{\circ} 30,905^{\prime} \mathrm{S} 45^{\circ} 09,285^{\prime} \mathrm{W}$ & 8,5 & $29 / 06 / 2005$ & mini-multicorer \\
\hline 3 & $23^{\circ} 31,972^{\prime} \mathrm{S} 45^{\circ} 08,398^{\prime} \mathrm{W}$ & 11 & $29 / 06 / 2005$ & mini-multicorer \\
\hline 4 & $23^{\circ} 34,087^{\prime} \mathrm{S} 45^{\circ} 06,604^{\prime} \mathrm{W}$ & 17,5 & $29 / 06 / 2005$ & mini-multicorer \\
\hline 5 & $23^{\circ} 26,248^{\prime} \mathrm{S} 45^{\circ} 03,397^{\prime} \mathrm{W}$ & 5 & $28 / 06 / 2005$ & mini-multicorer \\
\hline 6 & $23^{\circ} 26,192^{\prime} \mathrm{S} 45^{\circ} 02,599^{\prime} \mathrm{W}$ & 8,2 & $28 / 06 / 2005$ & mini-multicorer \\
\hline 7 & $23^{\circ} 26,257^{\prime} \mathrm{S} 45^{\circ} 01,012^{\prime} \mathrm{W}$ & 12,5 & $28 / 06 / 2005$ & mini-multicorer \\
\hline 8 & $23^{\circ} 26,260^{\prime} \mathrm{S} 44^{\circ} 58,650^{\prime} \mathrm{W}$ & 18,5 & $28 / 06 / 2005$ & mini-multicorer \\
\hline 1 & $23^{\circ} 30,073^{\prime} \mathrm{S} 45^{\circ} 10,266^{\prime} \mathrm{W}$ & 4 & $26 / 08 / 2005$ & mini-multicorer \\
\hline 2 & $23^{\circ} 30,910^{\prime} \mathrm{S} 45^{\circ} 09,277^{\prime} \mathrm{W}$ & 8,5 & $26 / 08 / 2005$ & mini-multicorer \\
\hline 3 & $23^{\circ} 32,000^{\prime} \mathrm{S} 45^{\circ} 08,399^{\prime} \mathrm{W}$ & 11 & $26 / 08 / 2005$ & mini-multicorer \\
\hline 4 & $23^{\circ} 34,099^{\prime} \mathrm{S} 45^{\circ} 06,572^{\prime} \mathrm{W}$ & 17,5 & $26 / 08 / 2005$ & mini-multicorer \\
\hline 5 & $23^{\circ} 26,261^{\prime} \mathrm{S} 45^{\circ} 03,403^{\prime} \mathrm{W}$ & 5,5 & $24 / 08 / 2005$ & mini-multicorer \\
\hline
\end{tabular}




\begin{tabular}{|c|c|c|c|c|}
\hline 6 & $23^{\circ} 26,198^{\prime} \mathrm{S} 45^{\circ} 02,612^{\prime} \mathrm{W}$ & 8,2 & $24 / 08 / 2005$ & mini-multicorer \\
\hline 7 & $23^{\circ} 26,240^{\prime} \mathrm{S} 45^{\circ} 01,002^{\prime} \mathrm{W}$ & 12,5 & $24 / 08 / 2005$ & mini-multicorer \\
\hline 8 & $23^{\circ} 26,263^{\prime} \mathrm{S} 44^{\circ} 58,649^{\prime} \mathrm{W}$ & 18,5 & $24 / 08 / 2005$ & mini-multicorer \\
\hline 1 & $23^{\circ} 30,080^{\prime} \mathrm{S} 45^{\circ} 10,254^{\prime} \mathrm{W}$ & 4,3 & $4 / 11 / 2005$ & mini-multicorer \\
\hline 2 & $23^{\circ} 30,902^{\prime} \mathrm{S} 45^{\circ} 09,288^{\prime} \mathrm{W}$ & 8,5 & $4 / 11 / 2005$ & mini-multicorer \\
\hline 3 & $23^{\circ} 31,975^{\prime} \mathrm{S} 45^{\circ} 08,389^{\prime} \mathrm{W}$ & 10,5 & $4 / 11 / 2005$ & mini-multicorer \\
\hline 4 & $23^{\circ} 34,111^{\prime} \mathrm{S} 45^{\circ} 06,590^{\prime} \mathrm{W}$ & 17,7 & $4 / 11 / 2005$ & mini-multicorer \\
\hline 5 & $23^{\circ} 26,254^{\prime} \mathrm{S} 45^{\circ} 03,416^{\prime} \mathrm{W}$ & 5 & $6 / 11 / 2005$ & mini-multicorer \\
\hline 6 & $23^{\circ} 26,188^{\prime} \mathrm{S} 45^{\circ} 02,613^{\prime} \mathrm{W}$ & 8 & $6 / 11 / 2005$ & mini-multicorer \\
\hline 7 & $23^{\circ} 26,248^{\prime} \mathrm{S} 45^{\circ} 01,003^{\prime} \mathrm{W}$ & 13 & $6 / 11 / 2005$ & mini-multicorer \\
\hline 8 & $23^{\circ} 26,144^{\prime} \mathrm{S} 44^{\circ} 58,649^{\prime} \mathrm{W}$ & 19 & $6 / 11 / 2005$ & mini-multicorer \\
\hline
\end{tabular}

Perfis da coluna de água foram feitos utilizando-se um CTD (Condutivity, Temperature and Depth, SeaBird ${ }^{\circledR}$ ) e através da coleta de água de superfície e de fundo utilizando garrafas Van Dorn para análises de componentes bióticos e abióticos (Projeto DIAGEN).

A amostragem do sedimento foi realizada utilizando-se um mini-multicorer, com capacidade para coletar três testemunhos simultaneamente (tubos de acrílico de $10 \mathrm{~cm}$ de diâmetro e $50 \mathrm{~cm}$ de altura). O sedimento de cada testemunho foi fatiado a bordo em três horizontes $(0-2,2-5$ e 5-10 cm) e alocados em local adequado para cada análise realizada.

\subsection{Análise granulométrica}

O tamanho dos grãos foi determinado usando as técnicas de peneiramento e pipetagem (Suguio, 1973). A classificação granulométrica foi obtida segundo os parâmetros estatísticos de Folk \& Ward (1957) e diagrama triangular de Shepard (1954).

\subsection{Contagem bacteriana.}

Para a análise da comunidade bacteriana foram coletadas amostras em triplicata em cada estação de coleta em todos os meses de estudo. De cada fatia de sedimento amostrada, $1 \mathrm{ml}$ de sedimento foi retirado com seringa estéril e alocado em potes de plástico com $5 \mathrm{ml}$ de formol $2 \%$ pré-filtrado em filtro $0,2 \mu \mathrm{m}$. As amostras foram armazenadas em local escuro a $4^{\circ} \mathrm{C}$ mantidas sob as mesmas condições até a análise laboratorial. 
Em laboratório, cada amostra de sedimento foi transferida para tubos de centrífuga, previamente esterilizados em câmara UV (24 h) e adicionados $4 \mathrm{~mL}$ de formol filtrado $2 \%$ (filtro Acrodisc Gelman Science ${ }^{\circledR}$ 0,2 $\mu \mathrm{m}$ ). As amostras foram diluídas (1:10 vezes) e submetidas à ultrasonificação (Thorton T14) por quatro períodos de 1 min a 100 $\mathrm{W}$, com intervalos de $30 \mathrm{~s}$. Este processo foi realizado para desprender as bactérias aderidas aos grãos do sedimento (Montagna, 1982). Após a sedimentação das partículas, subamostras do sobrenadante foram retiradas e diluídas (1:1000 vezes) em formol filtrado $2 \%$.

Posteriormente, as amostras descansaram por $5 \mathrm{~min}$ após adição de 0,5 $\mathrm{ml}$ de alaranjado de acridina (0,01\%). Estas foram filtradas utilizando-se unidade de filtração equipada com um filtro policarbonato black (Poretics ${ }^{\circledR}, 0,22 \mu \mathrm{m}$ de poro) e uma rede de nylon com malha de $5 \mu \mathrm{m}$ posicionada sob o filtro. Após a filtração, o filtro foi retirado e colocado sobre uma lâmina. As lâminas foram analisadas em microscópio de epifluorescência Nikon ${ }^{\circledR}$ Otihot (lâmpada HBO 50 W, filtro 515 KP, luz de excitação azul) (Zimmermann et al., 1978). Um retículo 8x8, previamente montado na objetiva, foi usado para as contagens. Apenas as bactérias que se encontravam dentro do retículo foram contabilizadas. O número de campos a ser contado foi determinado a partir do diagrama de Cassel (Cassel, 1965) e determinou-se a contagem de 40 campos por lâmina. Apenas corpos com clara distinção de contorno, forma e coloração (verde fluorescente) foram quantificados (Meyer-Reil, 1983; Boetius, comunicação pessoal) (Figura 3). As bactérias livres ou aderidas ao detrito foram discriminadas quanto a sua forma (cocos, bastonetes, filamentosas, espirulinas e víbrio). Adicionalmente, o número de células bacterianas em divisão (aquelas que apresentaram clara invaginação) foi analisado como uma medida de atividade bacteriana (Hangströn et al., 1979). Em cada campo, duas células foram escolhidas coincidentemente (escolheu-se células de um mesmo quadrado do retículo previamente determinado) e através de um retículo milimetrado foram realizadas medidas de comprimento e largura para o cálculo da biomassa. 


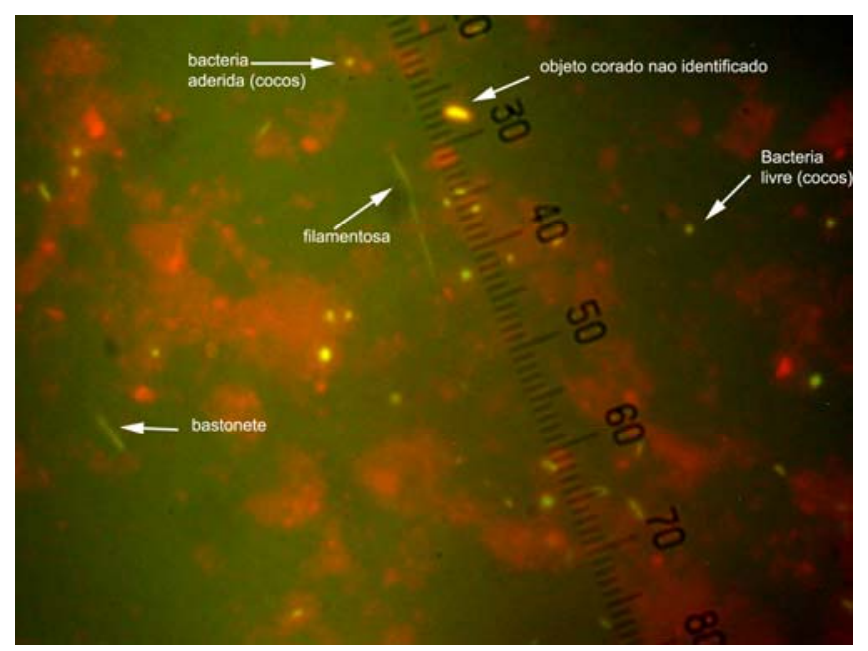

Figura 3: Bactérias vistas ao microscópio de epifluorescência, objetiva de 100X.

A densidade bacteriana foi calculada a partir da fórmula:

$$
\begin{gathered}
\text { densidade }(\text { células } / \mathrm{ml})=\frac{(C C-B C) \times M F \times D F}{\text { volume de sub-amostra filtrada }}
\end{gathered}
$$

Onde:

CC: média de células por campo

BC: média de células no branco

MF: fator do microscópio (área do filtro/área do gride de contagem)

DF: fator de diluição

O valor encontrado foi convertido para células $\mathrm{g}^{-1}$ de sedimento seco, a partir do peso de $1 \mathrm{~cm}^{3}$ de sedimento seco específico para cada amostra.

A biomassa bacteriana ( $\mu \mathrm{gC} \mathrm{g}^{-1}$ de sedimento) foi estimada através do volume celular convertido em biovolume (número de células $\mathrm{g}^{-1} \mathrm{X}$ média do volume celular). $\mathrm{O}$ volume foi calculado de acordo com a fórmula de Bratbak (1985):

$$
V\left(\mu m^{-3}\right)=\frac{\prod}{4} x W^{2} x\left(L-\frac{W}{3}\right) \quad \begin{aligned}
& \text { Onde: } \\
& \text { W: largura } \\
& \text { L: comprimento }
\end{aligned}
$$




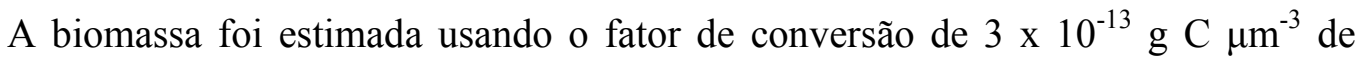
biovolume (Børsheim et al., 1990).

Foram apresentados resultados dos valores médios (média entre três réplicas) observados em cada estrato do sedimento e inventários observados em cada estação. Inventários ou valores integrados foram calculados a partir da soma ponderada de cada fatia do estrato $(0-2+1,5 \times 2-5+2,5 \times 5-10)$.

\subsection{Normalizações.}

Para efeito de comparação, foram realizadas normalizações dos dados de bactéria (número de células) para a quantidade de água intersticial e para a porosidade do sedimento.

A quantidade de água foi obtida por diferença gravimétrica após secagem de $1 \mathrm{ml}$ de sedimento úmido em estufa a $60^{\circ} \mathrm{C}$ por 24 horas.

A porosidade foi calculada através da fórmula:

$\varphi=\beta \cdot \mathrm{d} / 100 \quad$ onde $\beta$ : quantidade de água em $\%$

d: densidade do sedimento

Os dados referentes à camada superficial $(0-2 \mathrm{~cm})$ do sedimento foram normalizados para COT através da divisão dos valores de densidade (cel/g de sedimento seco) e biomassa ( $\mu \mathrm{g} / \mathrm{g}$ de sedimento seco) pelos valores obtidos de COT (dados em $\mathrm{g} / \mathrm{g}$ de sedimento seco).

\subsection{Análises estatísticas.}

Para a comparação entre os resultados de densidade e biomassa bacteriana utilizou-se o teste paramétrico ANOVA. Nos casos em que foram detectadas diferenças significativas $(\alpha \leq 0,05)$ entre períodos, estações de coleta e estratos da coluna sedimentar, foi aplicado o teste pós-hoc de comparações múltiplas de Tukey. Quando os dados não permitiram o uso de teste paramétrico, utilizou-se o teste não paramétrico de Kruska-Wallis associado ao teste de Dun (Zar, 1996).

Através dos dados obtidos de densidade e biomassa bacteriana, foram realizados testes de correlação de Pearson para investigar a relação entre os dados de comunidade bacteriana e os dados bióticos (MOT, clorofila-a, feopigmentos, ATP e fauna) e abióticos 
(temperatura, granulometria) adicionais, obtidos durante o projeto DIAGEN. Os testes foram realizados utilizando-se os valores integrados para a coluna sedimentar (i.e. $10 \mathrm{~cm}$ superficiais). Os resultados foram testados quanto à variação espacial ( $n=24)$ e em cada enseada separadamente $(n=12)$, e também quanto à variação temporal em cada estação de coleta $(n=12)$.

A camada superficial do sedimento $(0-2 \mathrm{~cm})$ foi analisada separadamente quanto aos dados adicionais através de testes de correlação de Pearson. Todos os valores foram normalizados para COT e testados espacial e temporalmente. Adicionalmente, testes de correlação foram realizados com valores de densidade e biomassa bacteriana da camada superficial e valores de biomarcadores lipídicos, nos meses de fevereiro e agosto.

A análise de componentes principais (PCA) foi realizada com o objetivo de detectar e descrever os mais prováveis processos bióticos e abióticos responsáveis pela variabilidade espacial e temporal apresentada pela comunidade nas áreas estudadas. Foram utilizados valores integrados de biomassa bacteriana, clorofila-a, feopigmentos, ATP, MOT, temperatura de fundo e porcentagem de areia e de sedimentos finos, estação e período de coleta.

Para as análises ANOVA e de correlação foi utilizado o pacote estatístico Bioestat 4.0. O programa estatístico MVSP (Multivariate Statistical Package) foi utilizado para a análise de PCA.

\subsection{Balanço de carbono}

O intuito deste estudo foi analisar a contribuição da comunidade microbiana para o COT e a diferença de contribuição entre os diferentes organismos da comunidade microbiana.

O balanço de carbono foi realizado na camada superficial do sedimento (0-2) de cada enseada em cada mês de coleta. A porcentagem de contribuição de cada comunidade microbiana na concentração COT foi calculada a partir dos valores de biomassa microbiana (ATP), que avalia a biomassa da comunidade microbiana local, porém sem distinguir as diferentes classes de microorganismos (Karl \& Novitsky, 1988), biomassa de microorganismos fotoautotróficos (clorofila-a) e de biomassa bacteriana. Os valores de cada parâmetro microbiano (em $\mu \mathrm{g} \mathrm{C} \mathrm{g}^{-1}$ sedimento seco) foram representados mostrando a 
contribuição relativa de cada parcela da comunidade microbiana em cada estação e mês de coleta.

A contribuição da biomassa bacteriana para a biomassa microbiana (ATP) foi estimada utilizando-se valores integrados da coluna sedimentar. Para isso foi calculada a porcentagem de bactérias presentes na biomassa medida pela ATP.

\section{Resultados}

\subsection{Pluviosidade}

A pluviosidade da região de estudo foi obtida na Estação Meteorológica da Base Norte do Instituto Oceanográfico da USP, Ubatuba. Observou-se que o período de mais intensa precipitação foi janeiro, seguido de abril e março de 2005 (Figura 3). Neste ano, houve outro período de elevadas precipitações entre os meses de setembro e outubro (Figura 4). Maiores precipitações ocorreram no período do verão (dezembro a março) com média de $214 \mathrm{~mm}$ para o período. As menores precipitações ocorreram no inverno (junho a setembro) com média de precipitação de $132 \mathrm{~mm}$ para o período.

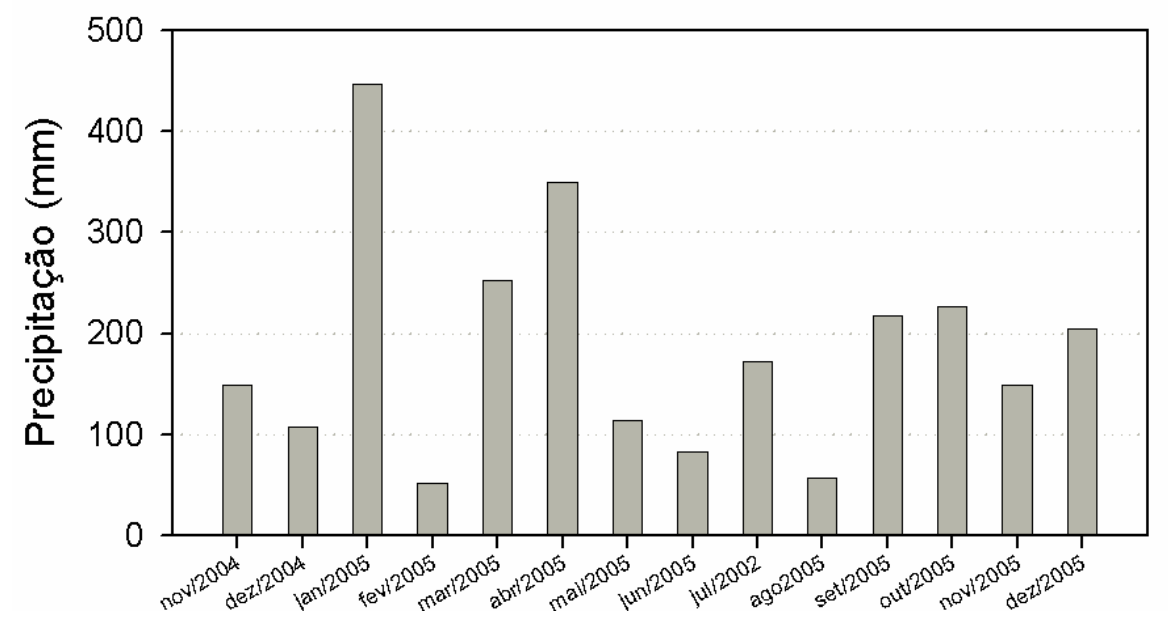

Figura 4: Pluviosidade da região de Ubatuba durante o período de coletas de amostras. Fonte: Estação Meteorológica da Base Norte do Instituto Oceanográfico da USP. 


\subsection{Ondas}

A altura e direção do trem de ondas ocorrendo na região de Ubatuba foram obtidas através do site www.waves.com.br. Os dados foram retirados de observações diárias do tamanho e direção das ondas na praia Grande (Ubatuba), localizada entre as enseadas de Ubatuba e Fortaleza e que recebe todas as ondulações predominantes (S-SE-NE) na região. Os meses de fevereiro, agosto e novembro de 2005 foram caracterizados pela predominância de ondas de pouca intensidade e de origem norte-nordeste (N-NE) (Figura 4). Já os meses de abril e junho de 2005, apresentaram maior incidência de ondas provenientes de sul-sudeste (S-SE) e de maior intensidade, em decorrência da maior quantidade de frentes frias presentes nestas épocas (Figura 5).

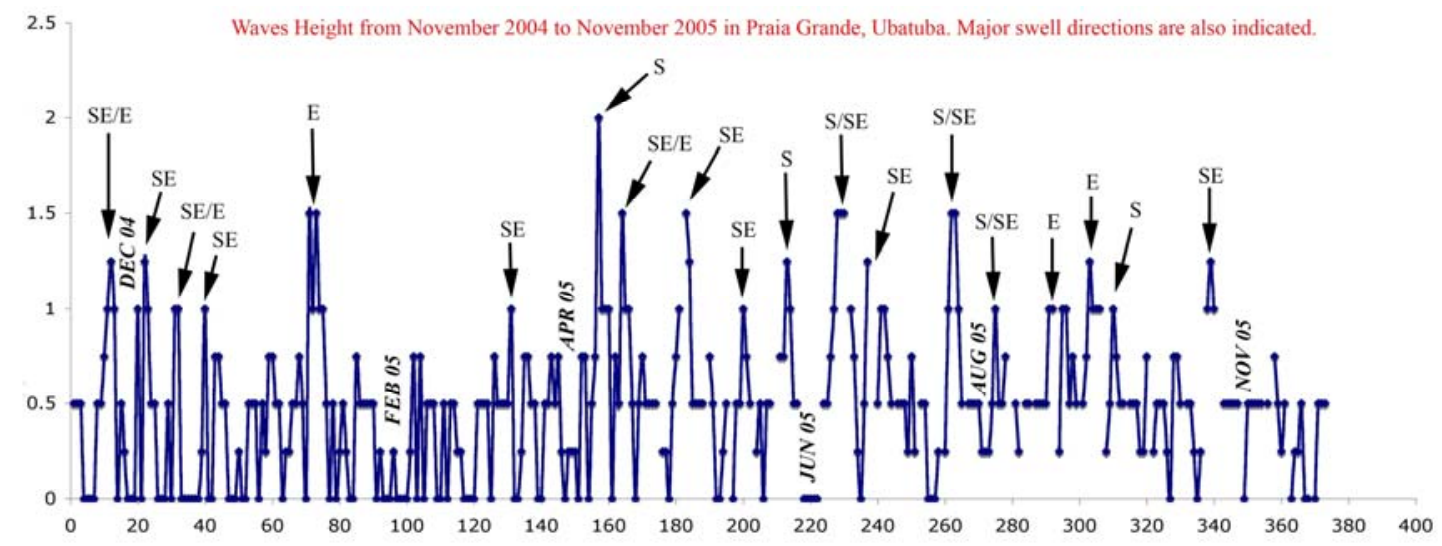

Figura 5: Altura e direção de ondas da região de Ubatuba durante o período de coleta das amostras (período medido em dias de dezembro de 2004 a novembro de 2005).

\subsection{Granulometria}

A composição dos sedimentos das enseadas, de acordo com a classificação de Shepard (1954), variou de areia a silte (Tabela 2). Na enseada de Fortaleza, a estação 1 geralmente apresentou altas porcentagens de areia, enquanto a estação 4 maiores porcentagens de silte. Já na enseada de Ubatuba, maiores porcentagens de silte foram encontradas nas estações 5 e 6, enquanto que nas estações 7 e 8 houve predominância de areia. 
Tabela 2: Resultados das análises granulométricas em cada estrato do sedimento $(1=0-2 \mathrm{~cm}, 2=2-5 \mathrm{~cm}$ e $3=5-10 \mathrm{~cm})$, nas enseadas de Fortaleza (estação 1 a 4) e Ubatuba (estação 5 a 8). ar = areia, $\mathrm{s}=$ silte, ar.s. = areia síltica, s.ar. = silte arenoso, s.ag. = silte argiloso, ar.ag. $=$ areia argilosa, s.ag.ar. $=$ silte argilo arenoso e gran. $=$ grânulo.

\begin{tabular}{|c|c|c|c|c|c|c|c|c|c|c|c|c|c|c|c|c|c|c|c|c|c|c|c|c|}
\hline \multirow{2}{*}{$\begin{array}{l}\text { Dezembro } \\
\text { Estrato }\end{array}$} & \multicolumn{3}{|c|}{ Estação 1} & \multicolumn{3}{|c|}{ Estação 2} & \multicolumn{3}{|c|}{ Estação 3} & \multicolumn{3}{|c|}{ Estação 4} & \multicolumn{3}{|c|}{ Estação 5} & \multicolumn{3}{|c|}{ Estação 6} & \multicolumn{3}{|c|}{ Estação 7} & \multicolumn{3}{|c|}{ Estação 8} \\
\hline & 1 & 2 & & 1 & 2 & 3 & 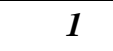 & 2 & 3 & 1 & 2 & ? & 1 & 2 & & 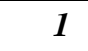 & 2 & & 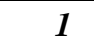 & 2 & 3 & 1 & 2 & 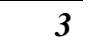 \\
\hline & 0 & 0 & 0 & 0 & 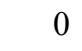 & 0 & 0 & 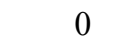 & 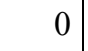 & 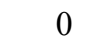 & & & 0 & 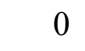 & & & 0 & & & & & & & \\
\hline & 0 & 0 & 0 & 0 & 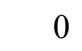 & 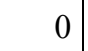 & 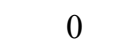 & & 0 & 0 & 0 & 0 & 59 & 9,15 & 5,02 & 0 & 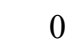 & & . & & 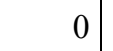 & 0 & & \\
\hline & 77,8 & 83 & 86,4 & 7,3 & 0,8 & 5,9 & 5,9 & & 42,6 &, 5 & 4,5 & 03 & 9 & 28,2 & 24,8 & 17 & 5,76 & 9,32 & 9,6 & 71,3 & 86 & 100 & 100 & 100 \\
\hline & 12 & 10 & 6,8 & 2 & 37,3 & 3,9 & & & 42,2 & & 5,4 & 76,1 & & 52,5 & 52,6 & & 62,3 & 84,3 & 25,3 & 16,9 & 6,97 & 0 & 0 & 0 \\
\hline & 10,2 & 6,8 & 6,8 & 55 & 11,9 & 15,2 & 33,7 & 25,5 & 15,2 & 5,2 & 20,1 & 15,9 & 0,4 & 10,2 & 17,5 & 8,4 & 32 & 6,36 & 15,2 & 11,8 & 6,97 & 0 & 0 & 0 \\
\hline & L & ar & ar & s. & ar.s. & s.ar. & s.ag. & s.ag.ar. & ar.s. & ar. & s.ag. & $\mathrm{s}$ & S.ar. & s.ar. & s.ar. & s.ag. & s.ag. & & ar.s. & ar.s. & & ar & ar & ar \\
\hline iro & \multicolumn{3}{|c|}{ Estação 1} & \multicolumn{3}{|c|}{ Estação 2} & \multicolumn{3}{|c|}{ Estação 3} & \multicolumn{3}{|c|}{ Estação 4} & \multicolumn{3}{|c|}{ Estação 5} & \multicolumn{3}{|c|}{ Estação 6} & \multicolumn{3}{|c|}{ Estação 7} & \multicolumn{3}{|c|}{ Estação 8} \\
\hline & 1 & 2 & & 1 & $?$ & 3 & 1 & 2 & 3 & 1 & 2 & 3 & 1 & 0 & & 4 & $?$ & & 4 & $?$ & & 4 & $?$ & \\
\hline & 0 & 0 & 0 & 0 & 0 & 0 & 0 & 0 & 0 & 0 & 0 & 0 & 0 & 0 & 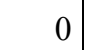 & c & 0 & & ( & 0 & 0 & 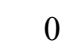 & 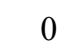 & 0 \\
\hline & 0 & 0 & 0 & 0 & 0 & 0 & 0 & 0 & 0 & 0 & 0 & 0 & 51 & 8,67 & 3,43 & 0 & 0 & 0 & 0 & 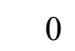 & 0 & 0 & 0 & 0,2 \\
\hline & 9,9 & 91 & 93,3 &, 5 & 42,8 & 0,3 & 56,7 & 75 & 55,2 &, 8 & 0,9 & 19,7 & 2 & 27,2 & 4,3 & 0 & 4,49 & 9,37 & 9,7 & 75 & 68,1 & 100 & 100 & 100 \\
\hline & 9 & 8,5 & 1,68 & ,9 & 38,7 & 47,6 & 30 & 6 & 26,5 & 8 & 64 & 65,2 & 9 & 47,3 & 53,7 & 6,2 & 65,4 & 60,4 & 43,5 & 18,4 & 13,4 & 0 & 0 & 0 \\
\hline & 5,09 & 0 & 5,03 & 16,6 & 18,5 & 22,1 & 13,3 & 11,64 & 18,2 & 13,4 & 15,2 & 15,1 & 20,4 & 16,9 & 28,5 & 13,8 & 30,2 & 30,2 & 36,8 & 6,68 & 18,5 & 0 & 0 & 0 \\
\hline & & $u_{1}$ & ar & & ar.s. & s.ar. & & & ar.s. & s.ar. & s.ar. & s.ar. & & s.ar. & s.ag. & & s.ag. & s.ag. & s.ag. & .s. & ar.ag. & ar & 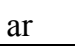 & ar \\
\hline $\mathrm{A}$ & \multicolumn{3}{|c|}{ Estação 1} & \multicolumn{3}{|c|}{ Estação 2} & \multicolumn{3}{|c|}{ Estação 3} & \multicolumn{3}{|c|}{ Estação 4} & \multicolumn{3}{|c|}{ Estação 5} & & ação & & & staçã & & & çar & 8 \\
\hline & 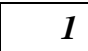 & & & 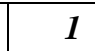 & & & 1 & & & 1 & & & - & & & & & & & & & & 2 & \\
\hline & 0 & 0 & 0 & 0 & 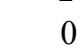 & 0 & 0 & 0 & 0 & c & 0 & & 0 & 0 & & & 0 & . & c & & & & 0 & \\
\hline & 0 & 0 & 03 & & 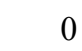 & 0,03 & 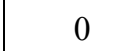 & 0 & 0 & 0 & 0 & & & 0,5 & & & 0 & 0 & 0 & & & & 0,1 & \\
\hline & 84,7 & 90 & 88,2 & 7 & 59,2 & 40,9 & 4,7 & 73 & 35,7 & 22,3 & 4,3 & 12,7 &, 5 & 17,2 & 17,8 & ,96 & 5,5 & 17,4 & 4,8 & 100 & 100 & 100 & 80 & 44 \\
\hline & 8,48 & 5 & 3,38 & 27 & 27,2 & 38,8 & & 27,01 & 40,6 & 67,1 & 62,2 & 63,8 &, 4 & 58,8 & 55,8 & & 64,1 & 55,6 & 6,78 & & 0 & & 6,7 & 12 \\
\hline ila & 6,78 & 5 & 8,44 & 15,2 & 13,6 & 20,2 & 18,5 & 20,26 & 23,7 & 10,6 & 23,5 & 23,5 & 28,5 & 23,5 & 23,7 & 30,6 & 30,4 & 27 & 8,47 & J & 0 & 0 & 13 & 44 \\
\hline & & $\mathrm{dI}$ & ar & ar.s. & ar.s. & ar.s. & ar.ag. & ar.s. & s.ar. & s.ar. & s.ag. & s.ag. & s.ag. & s.ag. & s.ag. & s.ag. & s.ag. & s.ag. & ar & $a_{1}$ & ar & ar & ar & ar \\
\hline & & tação & & & staçãc & & & stação 3 & & & stação & & & stação & & & stação & & & staçã & & & staçã & 108 \\
\hline & 1 & 2 & & - & & & 1 & 2 & U & - & & & - & & & & - & 5 & & 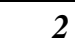 & & & 2 & \\
\hline & v & 0 & & 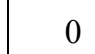 & 0 & 0 & 0 & 0 & 0 & 0 & 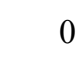 & & 0 & 0 & & ( & c & . & 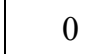 & 0 & 0 & & 0 & - \\
\hline & - & 0 & 0,44 & 0 & - & 0 & 0 & 0 & 0 & 0 & 0 & 0 & 03 & 0,24 & 0,87 & 0 & 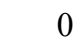 & 0 & 0 & & 0 & 0 & 0 & 0,1 \\
\hline & & 67 & 86,1 &, 5 & 54,6 & 34,3 & & 72 & 66,3 & 28,7 & 16,9 & 19,5 & 19,2 & 12,3 & 17,3 & 3,36 & 4,01 & 3,2 & 93,2 & 9,6 & 48,6 & 100 & 100 & 100 \\
\hline$\%$ silte & 17,1 & 20 & 3,37 & 28,7 & 26,9 & 43,8 & 50,5 & 20,14 & 18,6 & 57,7 & 74,1 & 62,1 & 80,8 & 46,3 & 55,7 & 49,2 & 57,3 & 53,4 & 5,11 & 8,63 & 29,1 & 0 & 0 & \\
\hline
\end{tabular}




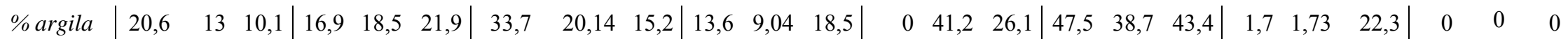

\begin{tabular}{|c|c|c|c|c|c|c|c|c|c|c|c|c|c|c|c|c|c|c|c|c|c|c|c|c|}
\hline Shepard & ar.ag & ar.s. & ar & ar.s. & ar.s. & s.ag. & ar.ag & ar.s. & ar.s. & s.ar. & s.ar. & s.ar. & $\mathrm{s}$ & S.ag. & s.ag. & s.ag & S.ag & s.ag. & & ar & ar.s. & & & \\
\hline Agosto & & tação & & & stação & & & tação 3 & & & tação & & & stação & & & tação & & & staçãc & & & tação & \\
\hline Estrato & 1 & 2 & 3 & 1 & 2 & 3 & 1 & 2 & 3 & 1 & 2 & 3 & 1 & 2 & 3 & 1 & 2 & 3 & 1 & 2 & 3 & 1 & 2 & 3 \\
\hline$\%$ seixos & 0 & 0 & 0 & 0 & 0 & 0 & 0 & 0 & 0 & 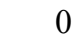 & 0 & 0 & 0 & 0 & 0 & 0 & 0 & 0 & 0 & 0 & 0 & 0 & 0 & 0 \\
\hline$\%$ gran. & 0 & 0 & 0 & 0 & 0,07 & 0 & 0 & 0 & 0 & 0 & 0 & 0 & 0 & 2,03 & 2,06 & 1,16 & 0 & 0 & 0 & 0 & 0 & 0 & 0 & 0 \\
\hline$\%$ areia & 83 & 72 & 67,9 & 57,9 & 59,2 & 35,6 & 64,9 & 56,57 & 52,7 & 27,2 & 20,8 & 13,1 & 9,99 & 22 & 18,2 & 18,3 & 5,03 & 8,39 & 53,8 & 63,3 & 58,2 & 95 & 95 & 88 \\
\hline$\%$ silte & 5,09 & 17 & 20,3 & 25,3 & 25,5 & 40,7 & 15 & 31,74 & 33,8 & 55,9 & 60,7 & 66,1 & 56,1 & 54,1 & 58,1 & 56,5 & 67,6 & 61,6 & 34,7 & 25 & 29,6 & 5 & 3,4 & 6,7 \\
\hline$\%$ argila & 11,9 & 12 & 11,8 & 16,8 & 15,3 & 23,7 & 20,1 & 11,69 & 13,5 & 16,9 & 18,5 & 20,9 & 34 & 22 & 21,6 & 24 & 26,4 & 30 & 11,6 & 11,7 & 12,2 & 0 & 1,7 & 5 \\
\hline Shepard & ar & ar.s. & ar.s. & ar.s. & ar.s. & s.ar. & ar.ag. & ar.s. & ar.s. & s.ar. & s.ar. & s.ag. & s.ag. & s.ag. & s.ag. & s.ag. & s.ag. & S.ag. & ar.s. & ar.s. & ar.s. & ar & ar & ar \\
\hline Novembro & & tação & & & tação & & & tação 3 & & & tação & & & tação & & & tação & & & staçãc & & & tação & \\
\hline Estrato & 1 & 2 & 3 & 1 & 2 & 3 & 1 & 2 & 3 & 1 & 2 & 3 & 1 & 2 & 3 & 1 & 2 & 3 & 1 & 2 & 3 & 1 & 2 & 3 \\
\hline$\%$ seixos & 0 & 0 & 0 & 0 & 0 & 0 & 0 & 0 & 0 & 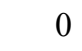 & 0 & 0 & 0 & 0 & 0 & --- & - & --- & 0 & 0 & 0 & 0 & 0 & 0 \\
\hline$\%$ gran. & 0 & 0 & 0 & 0 & 0 & 0 & 0 & 0 & 0 & 0 & 0 & 0 & 0 & 0,07 & 2,58 & --- & --- & --- & 0 & 0 & 0 & 0,8 & 1,7 & 1,4 \\
\hline$\%$ areia & 81,2 & 83 & 79,4 & 15,4 & 28 & 41 & 39,6 & 51,72 & 49,1 & 17,7 & 18 & 20,8 & 15,1 & 14,6 & 20,1 & --- & --- & --- & 96,5 & 79,1 & 74,4 & 99 & 98 & 21 \\
\hline$\%$ silte & 8,55 & 8,4 & 10,3 & 62,6 & 57 & 45,5 & 42 & 36,21 & 35,6 & 61,8 & 63,6 & 65,1 & 66,2 & 64,9 & 56,7 & --- & --- & --- & 3,48 & 12,2 & 18,8 & 0 & 0 & 62 \\
\hline$\%$ argila & 10,3 & 8,4 & 10,3 & 22 & 15,1 & 13,5 & 18,5 & 12,07 & 15,3 & 20,6 & 18,4 & 14,1 & 18,7 & 20,5 & 20,6 & --- & --- & --- & 0 & 8,69 & 6,84 & 0 & 0 & 15 \\
\hline Shepard & ar & ar & ar & s.ag. & s.ar. & s.ar. & s.ar. & ar.s. & ar.s. & s.ag. & s.ag. & s.ar. & s.ag. & s.ag. & s.ag. & --- & --- & --- & ar & ar & ar.s. & ar & ar & s.ar. \\
\hline
\end{tabular}

--- sem dados 


\subsection{Distribuição espaço-temporal da comunidade bacteriana}

Valores integrados da comunidade bacteriana variaram entre $2,5 \times 10^{9}$ e $1,8 \times 10^{8}$ células $\mathrm{g}^{-1}$ de sedimento seco (cel g ${ }^{-1}$ ss) e a biomassa, entre 187,3 e $27,1 \mu \mathrm{g} \mathrm{C} \mathrm{g}^{-1}$ ss. Foram encontradas maiores porcentagens de células do tipo cocos (Figura 6). As bactérias livres foram mais abundantes do que as aderidas ao detrito (Figura 7) em todos os meses e estações

estudadas.

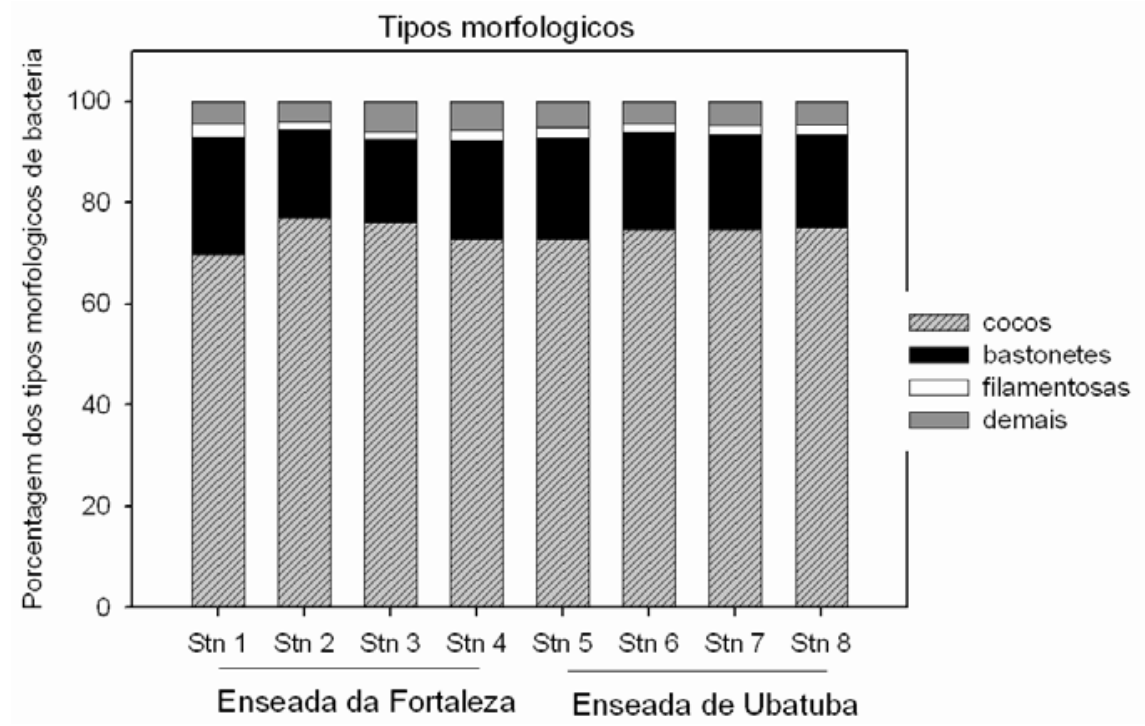

Figura 6: Porcentagens médias dos valores de cada tipo morfológico de bactéria encontradas em cada estação de coleta durante todo o período amostral.

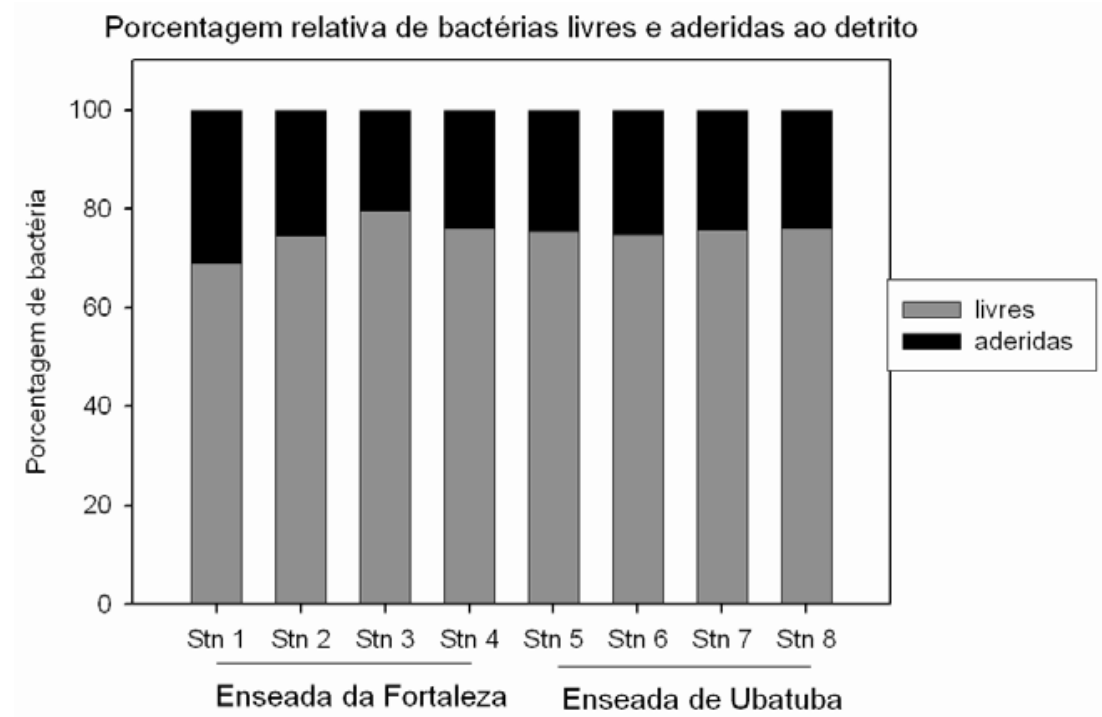

Figura 7: Porcentagens médias dos valores de bactéria livre e aderida ao detrito encontradas em cada estação de coleta durante o período amostral. 
Os maiores valores de densidade e biomassa bacterianas foram encontrados, de um modo geral, em junho de 2005 (Figuras 8 e 9). A única exceção foi a estação 8 , que apresentou maiores valores em fevereiro de 2005. Para cada estação, foram realizados testes de ANOVA, que mostraram diferenças significativas $(p<0,05)$ entre os meses coletados, com exceção das estações 2 e 3 para biomassa e estação 2 para densidade (Tabelas 3 e 4).

Em todos os meses de estudo, exceto agosto de 2005, foram encontrados maiores valores de densidade e biomassa bacterianas na estação 6 (Figuras 8 e 9). Testes estatísticos mostraram diferenças significativas entre as estações de coleta em todos os meses estudados (Tabela 5).

A Enseada de Ubatuba apresentou densidade e biomassa bacterianas significativamente diferentes entre as estações de coleta em todos os meses estudados (Tabela 6). Já a Enseada de Fortaleza apresentou diferenças significativas entre os valores de densidade bacteriana em dezembro de 2004 e abril e novembro de 2005, com maiores valores na estação 2. Em fevereiro de 2005, os maiores valores foram encontrados na estação 4 (Tabela 6). Valores de biomassa foram significativamente diferentes apenas na estação 2 em novembro de 2005 (Tabela 6).
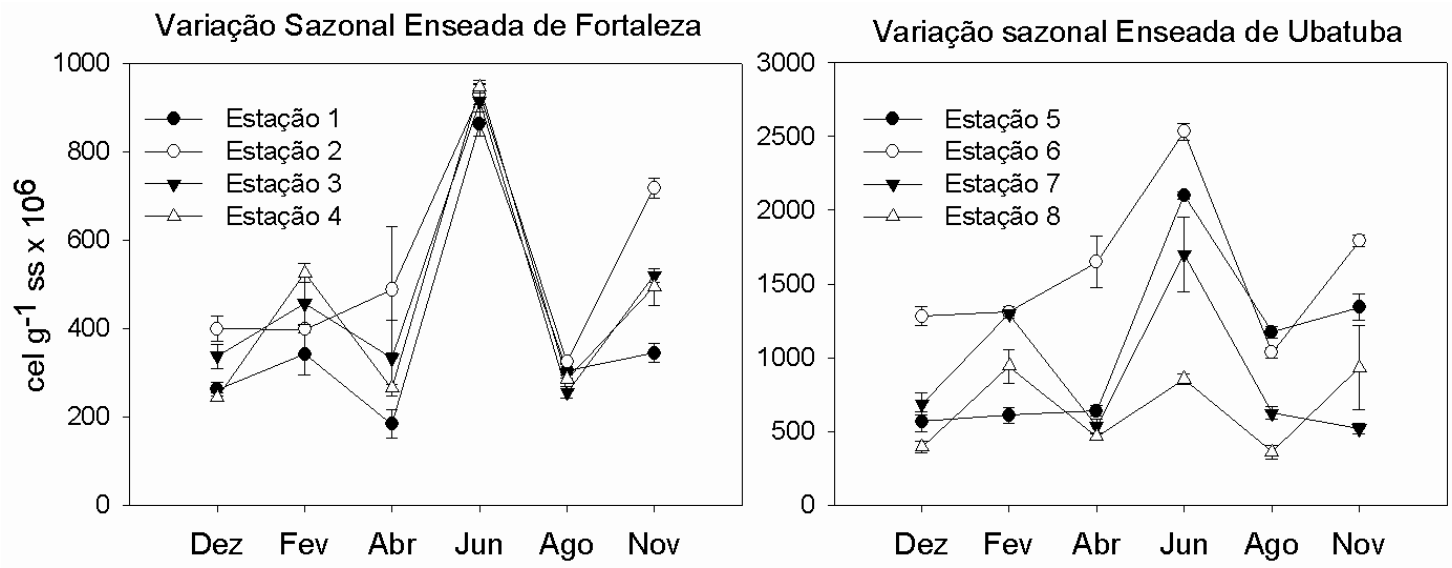

Figura 8: Variação temporal dos valores médios integrados de densidade bacteriana das estações de coleta nas Enseadas de Fortaleza e Ubatuba. Barras verticais indicam o erro padrão. 

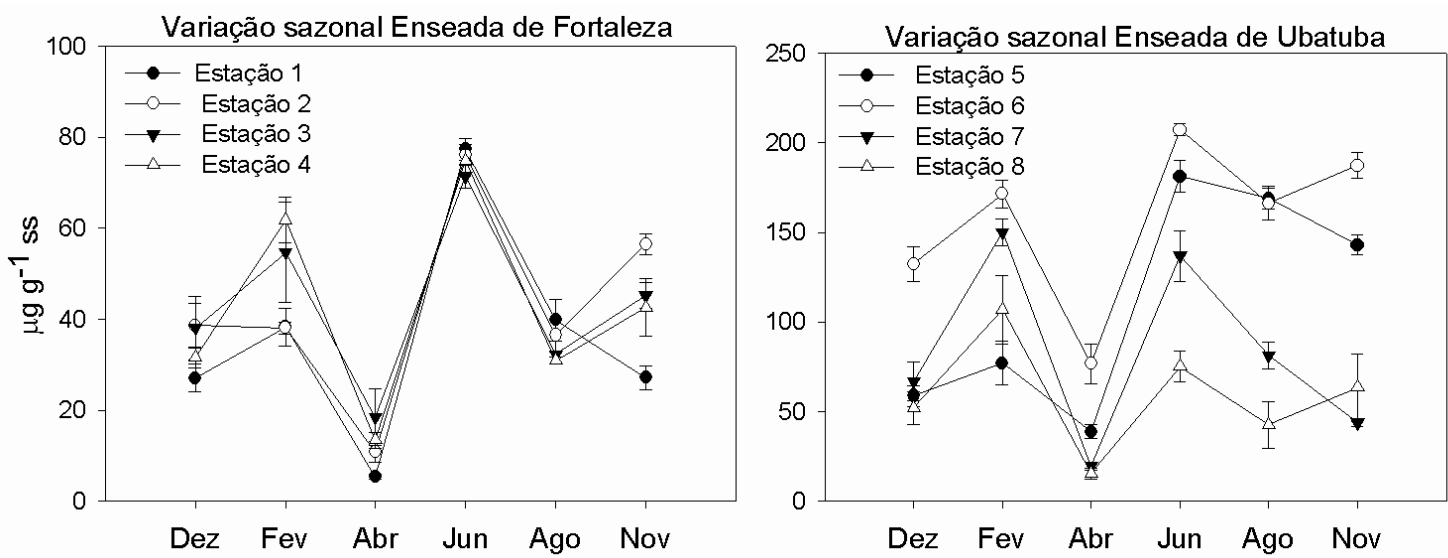

Figura 9: Variação temporal dos valores médios integrados de biomassa bacteriana nas estações de coleta nas Enseadas de Fortaleza e Ubatuba. Barras verticais indicam o erro padrão.

Tabela 3: Resultados estatísticos do teste ANOVA ou Kruskal-Wallis entre valores médios de densidade bacteriana nos meses de coleta em cada estação $(p<0,05)$. ns: valores do testes não apresentaram diferenças significativas $(\mathrm{p}>0,05)$.

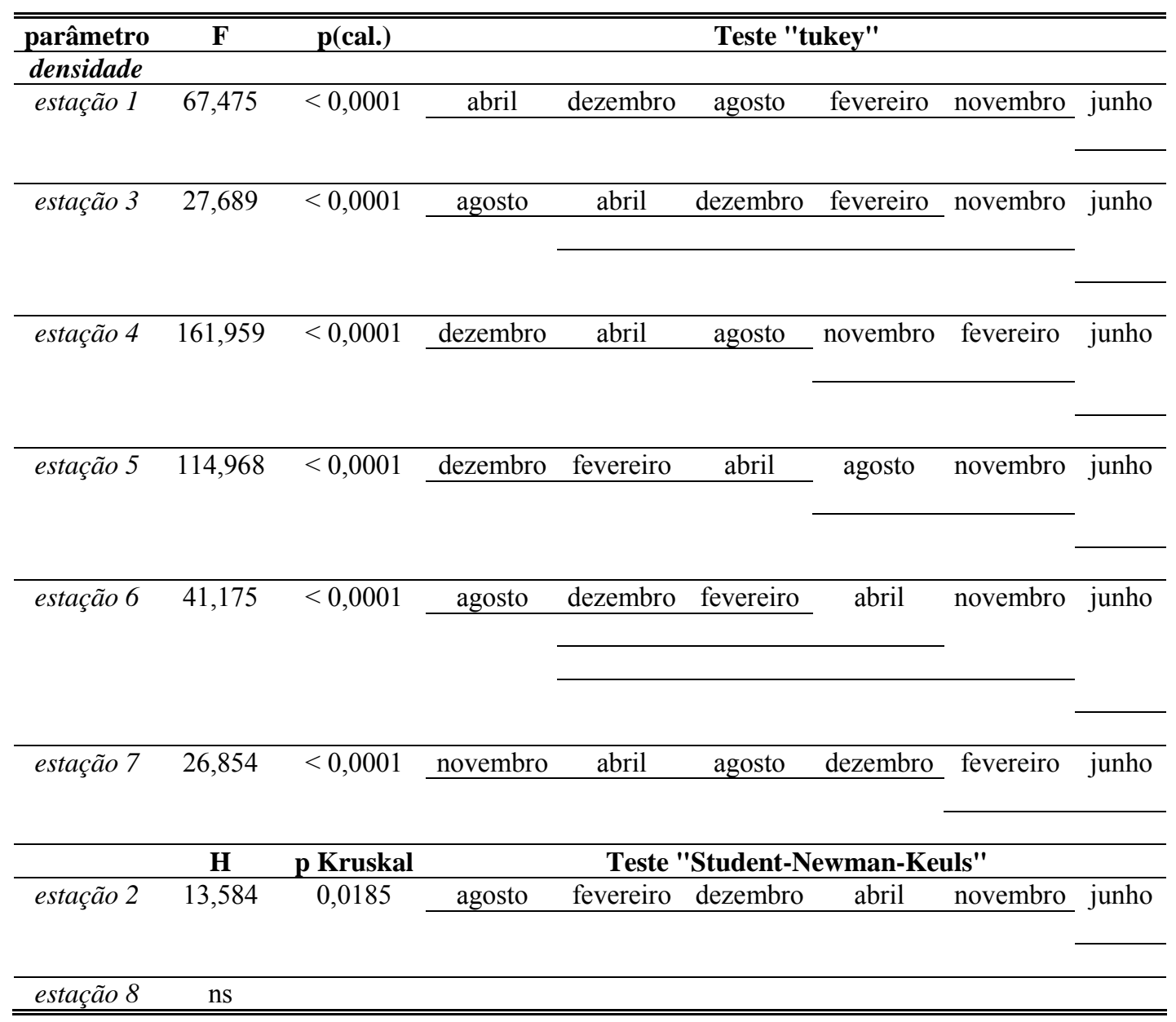


Tabela 4: Resultados estatísticos do teste ANOVA ou Kruskal-Wallis entre valores médios de biomassa bacteriana nos meses de coleta em cada estação $(p<0,05)$. ns: valores do testes não apresentaram diferenças significativas $(\mathrm{p}>0,05)$.

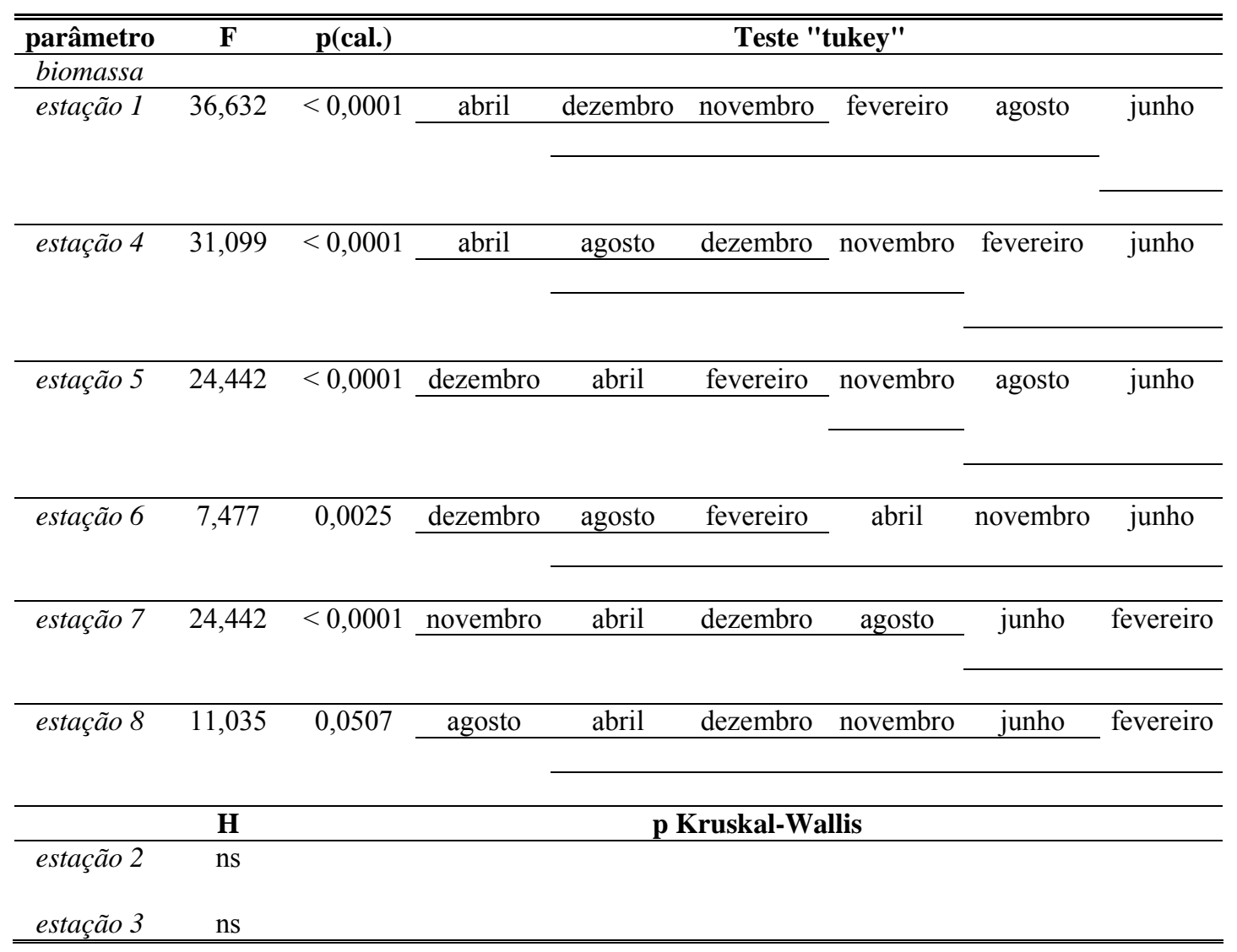


Tabela 5: Resultados estatísticos do teste ANOVA ou Kruskal-Wallis entre valores médios de densidade e biomassa bacteriana entre as estações em cada mês de coleta $(p<0,05)$. ns: valores do testes não apresentaram diferenças significativas $(p>0,05)$.

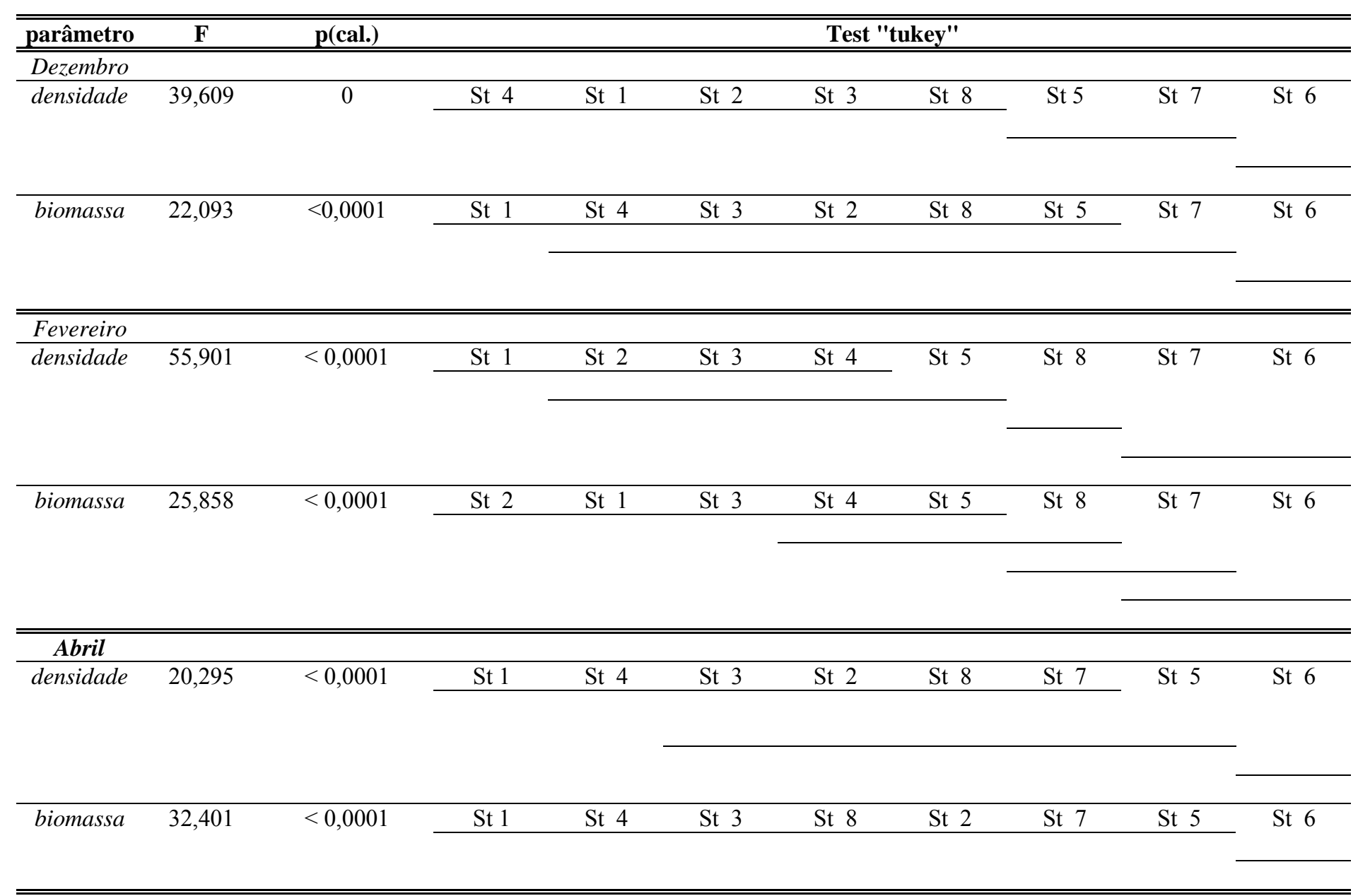




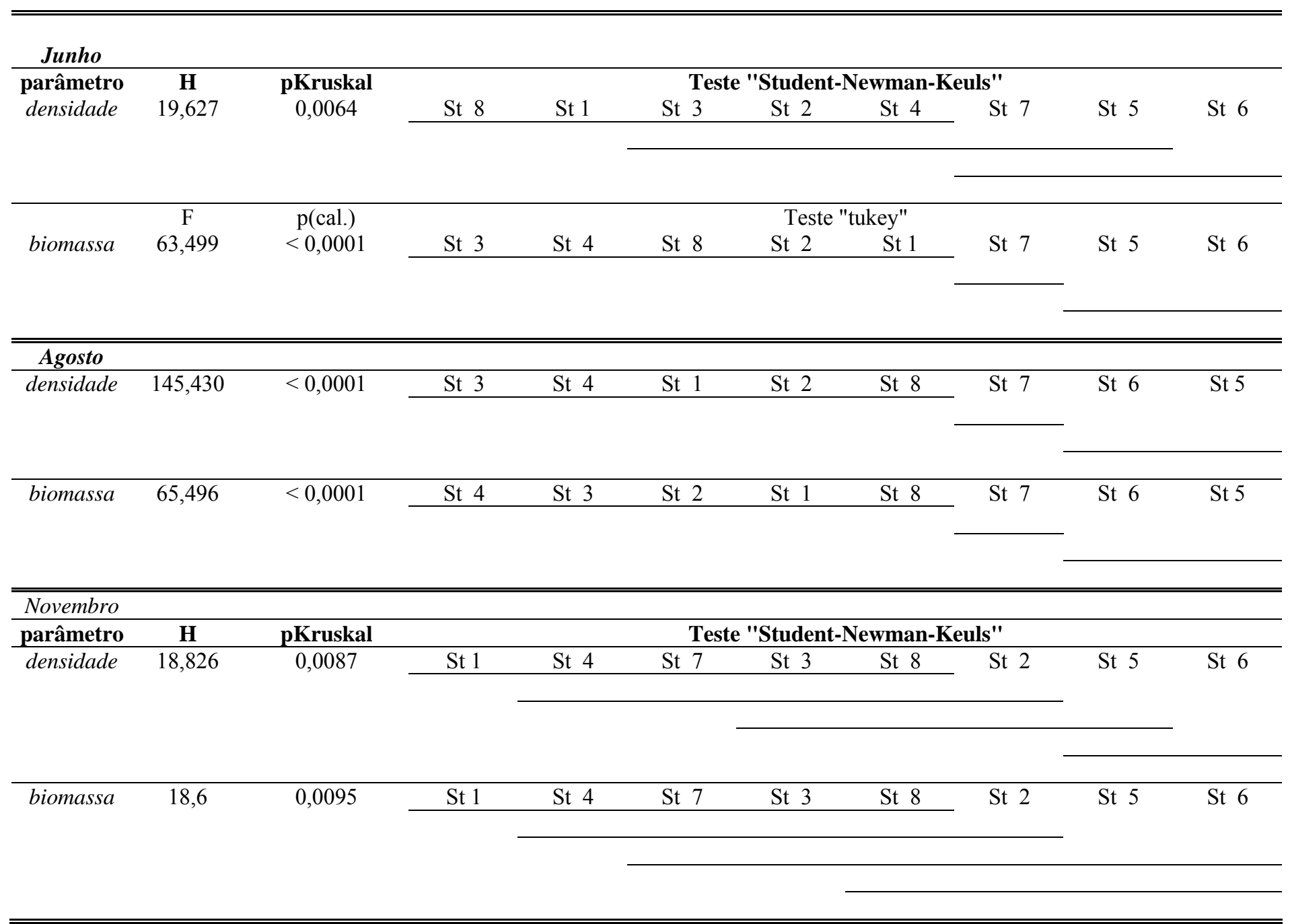


Tabela 6: Resultados estatísticos do teste ANOVA ou Kruskal-Wallis entre valores médios de densidade e biomassa bacteriana entre as estações de cada enseada em cada mês de coleta $(p<0,05)$. ns: valores do testes não apresentaram diferenças significativas $(p>0,05)$.

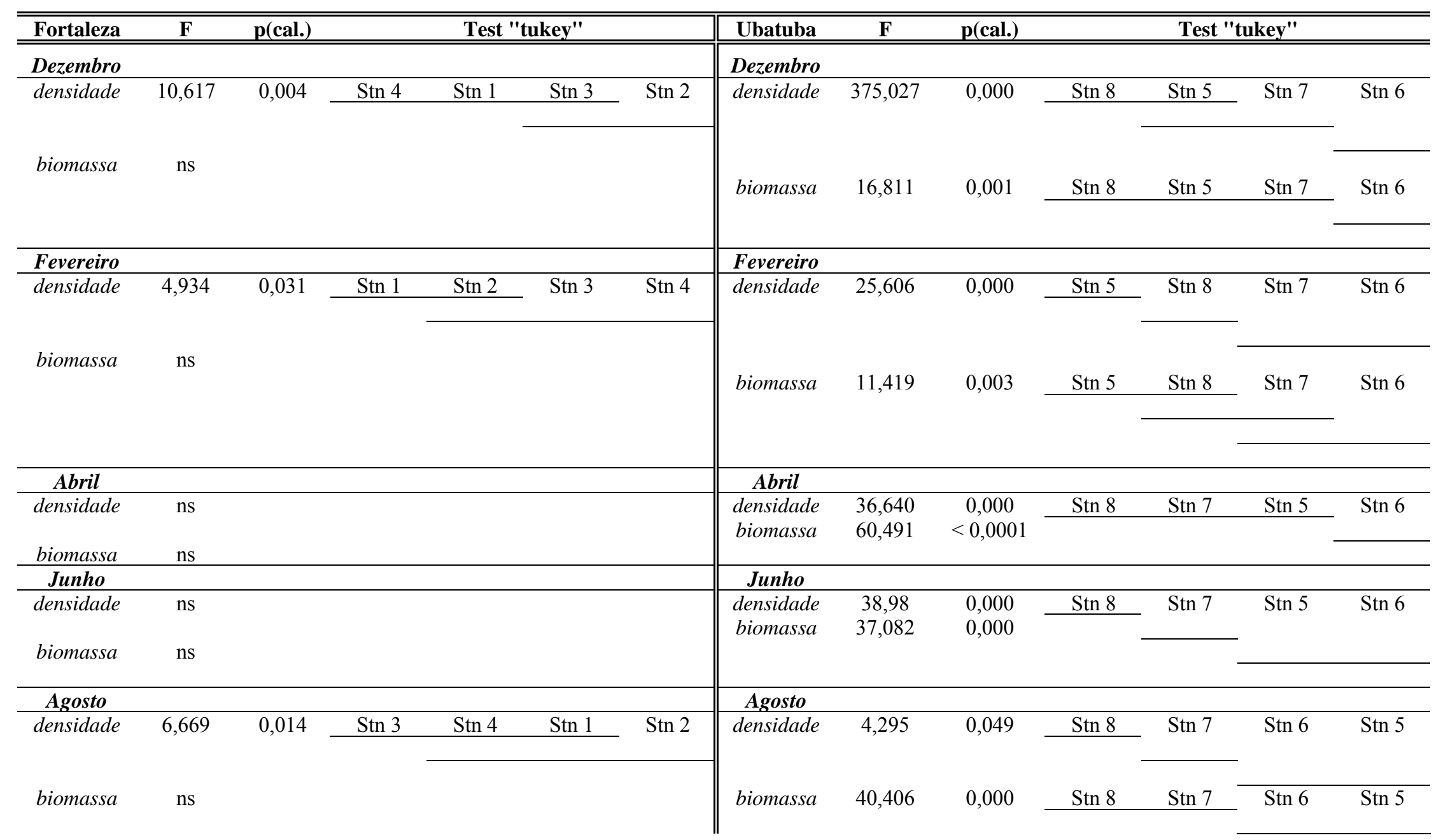




\begin{tabular}{|c|c|c|c|c|c|c|c|c|c|c|c|c|c|}
\hline \multirow{2}{*}{$\begin{array}{l}\text { Novembro } \\
\text { densidade }\end{array}$} & \multirow[b]{2}{*}{31,717} & \multirow[b]{2}{*}{0,000} & \multirow[b]{2}{*}{ Stn 1} & \multirow[b]{2}{*}{ Stn 4} & \multirow[b]{2}{*}{ Stn 3} & \multirow[b]{2}{*}{ Stn 2} & \multicolumn{7}{|l|}{ Novembro } \\
\hline & & & & & & & biomassa & 41,944 & 0,000 & Stn 7 & Stn 8 & $\operatorname{Stn} 5$ & Stn 6 \\
\hline & & & & & & & densidade & $\boldsymbol{H}$ & pKruskal & \multicolumn{4}{|c|}{ Teste "Student-Newman-Keuls" } \\
\hline \multirow[t]{2}{*}{ biomassa } & 9,654 & 0,005 & Stn 1 & Stn 4 & Stn 3 & Stn 2 & \multirow[b]{2}{*}{ Novembro } & 9,461 & 0,027 & $\operatorname{Stn} 8$ & $\operatorname{Stn} 7$ & Stn 5 & Stn 6 \\
\hline & & & & & & & & 15,691 & 0,001 & Stn 7 & $\operatorname{Stn} 8$ & Stn 5 & Stn 6 \\
\hline
\end{tabular}


A média de células em divisão variou entre $2,1 \%$ e $21,3 \%$, com maiores porcentagens na estação 3 em todas as épocas estudadas, com exceção de novembro, quando a estação 1 apresentou maiores valores (Figura 10). Os maiores valores de divisão bacteriana foram encontrados no mês de agosto nas estações $2,5,6,7$ e 8 , e no mês de abril nas demais estações (Figura 10).
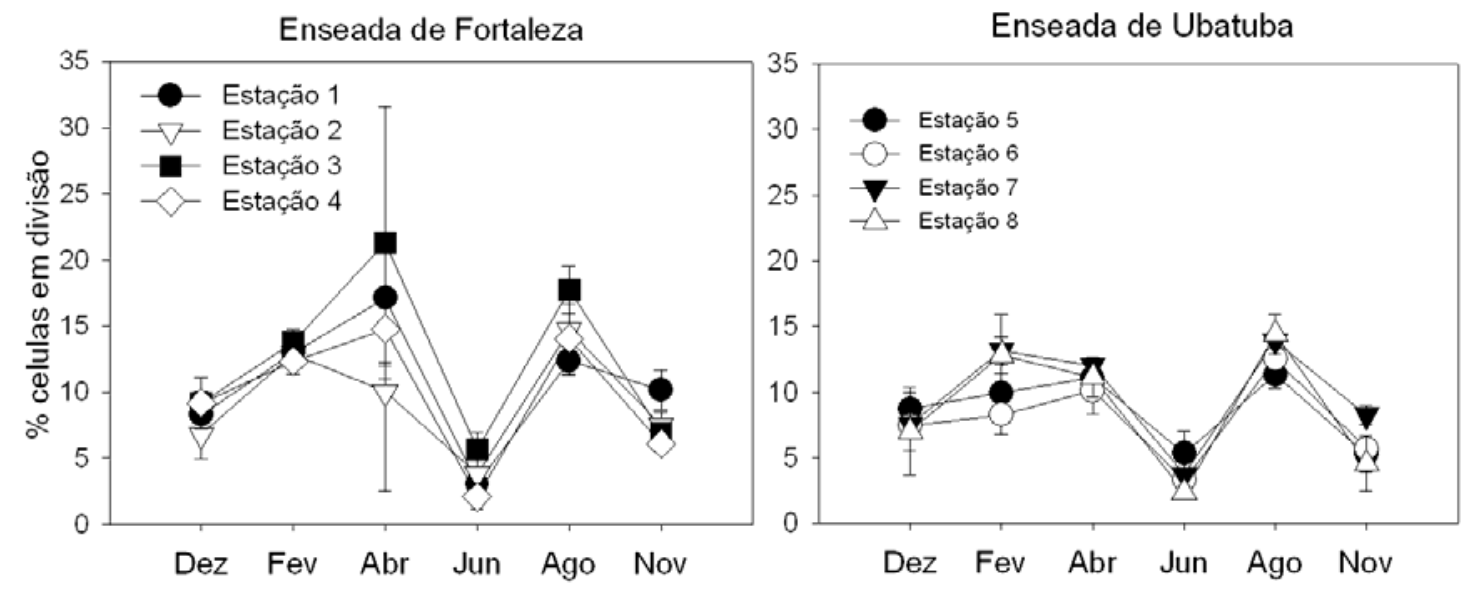

Figura 10: Variação temporal dos valores médios integrados de porcentagem de células em divisão nas estações de coleta nas Enseadas de Fortaleza e Ubatuba (linhas verticais indicam erro padrão).

\subsection{Correlações.}

Foram feitas análises de correlação entre os valores integrados de densidade e biomassa bacterianas e dados bióticos referentes à clorofila-a, matéria orgânica total (MOT), feopigmentos e biomassa microbiana (ATP) (Figuras 11 e 12), e os dados abióticos de temperatura de fundo e porcentagem de sedimentos finos (silte + argila) (Tabela 7). Os testes foram realizados para cada mês de coleta, com todas as estações estudadas e para cada enseada separadamente. Os testes também foram realizados para cada estação de coleta separadamente.

Espacialmente, a densidade e biomassa de bactérias apresentou correlação positiva com clorofila-a sedimentar na maioria dos meses de coleta, sendo que apenas no mês de fevereiro de 2005 não foi encontrada correlação significativa entre estes parâmetros (Tabela 8). Variação entre as correlações dos parâmetros foi observada dependendo do mês de coleta (Tabela 8). A temperatura de fundo e a porcentagem de sedimentos finos não foram significativamente correlacionadas com a densidade e biomassa bacteriana em nenhuma 
época estudada (Tabela 8). Em cada mês de coleta, na enseada de Fortaleza não foi observada correlação entre a variação espacial dos dados de densidade e biomassa bacteriana e os dados bióticos (Tabela 9). Apenas no mês de novembro de 2005 foi encontrada correlação significativa entre estes fatores (Tabela 9). Na enseada de Ubatuba, houve correlação positiva entre os dados bacterianos e a clorofila-a sedimentar (Tabela 9), com exceção das amostras coletadas no mês de fevereiro de 2005. Os outros resultados do teste mostraram variações entre as correlações dependendo do mês de coleta (Tabela 9).

A variação temporal da densidade e biomassa bacteriana observada em cada estação de coleta não mostrou correlação significativa com nenhum dado biótico ou abiótico. Correlações significativas foram observadas entre densidade e MOT na estação 5 $\left(\mathrm{r}_{\text {Pearson }}=\quad-0,613\right)$, e entre clorofila-a e densidade bacteriana na estação $6\left(\mathrm{r}_{\text {Pearson }}=\right.$ 0,685) (observar Figuras 8, 9, 11 e 12).
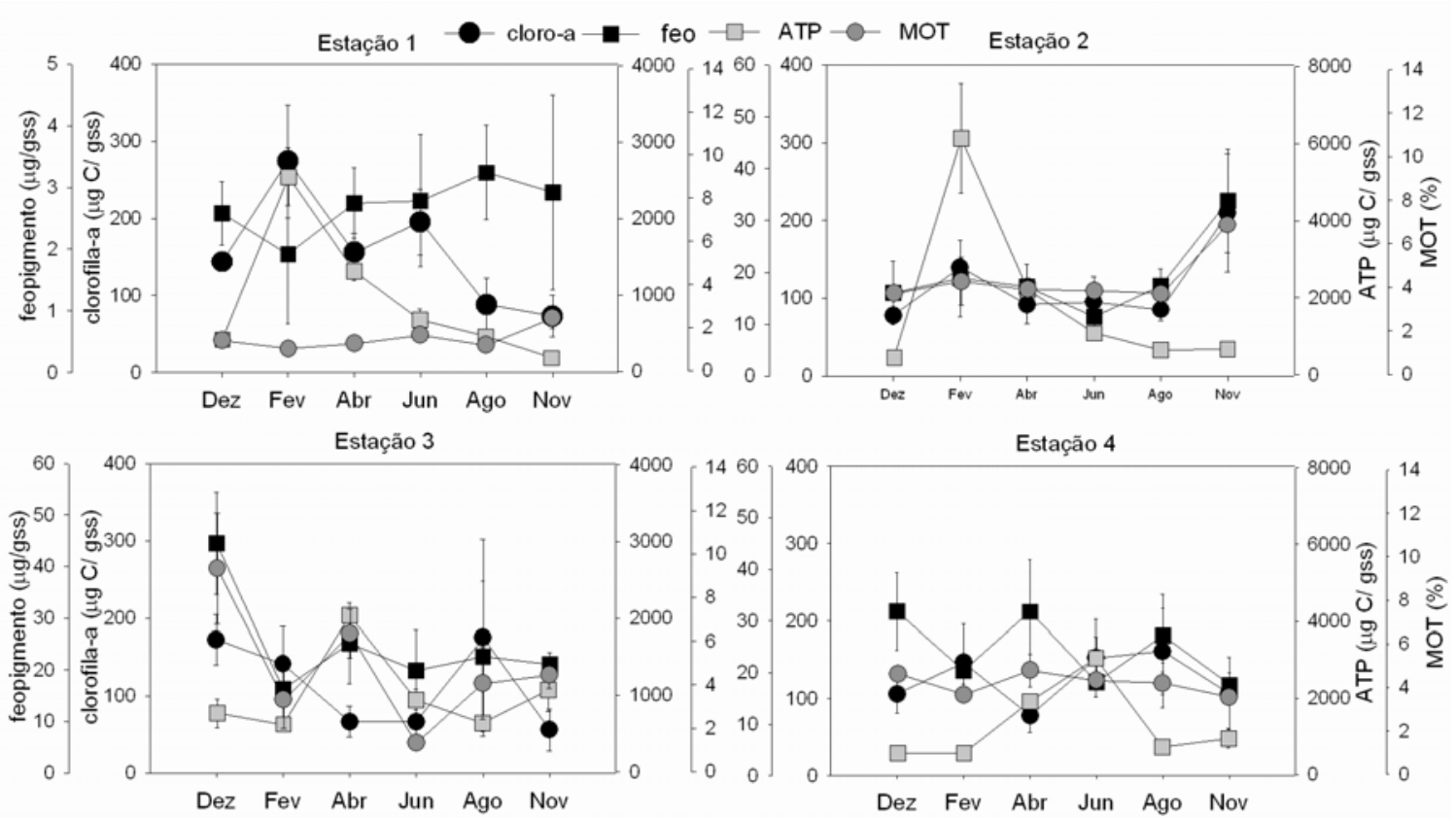

Figura 11: Valores médios integrados dos dados bióticos (MOT, clorofila-a, feopigmentos e ATP), da Enseada de Fortaleza (Estação 1 a 4) nos meses de coleta, barras verticais indicam o erro padrão. Fonte: Laboratório de Dinâmica Bêntica/IOUSP. 


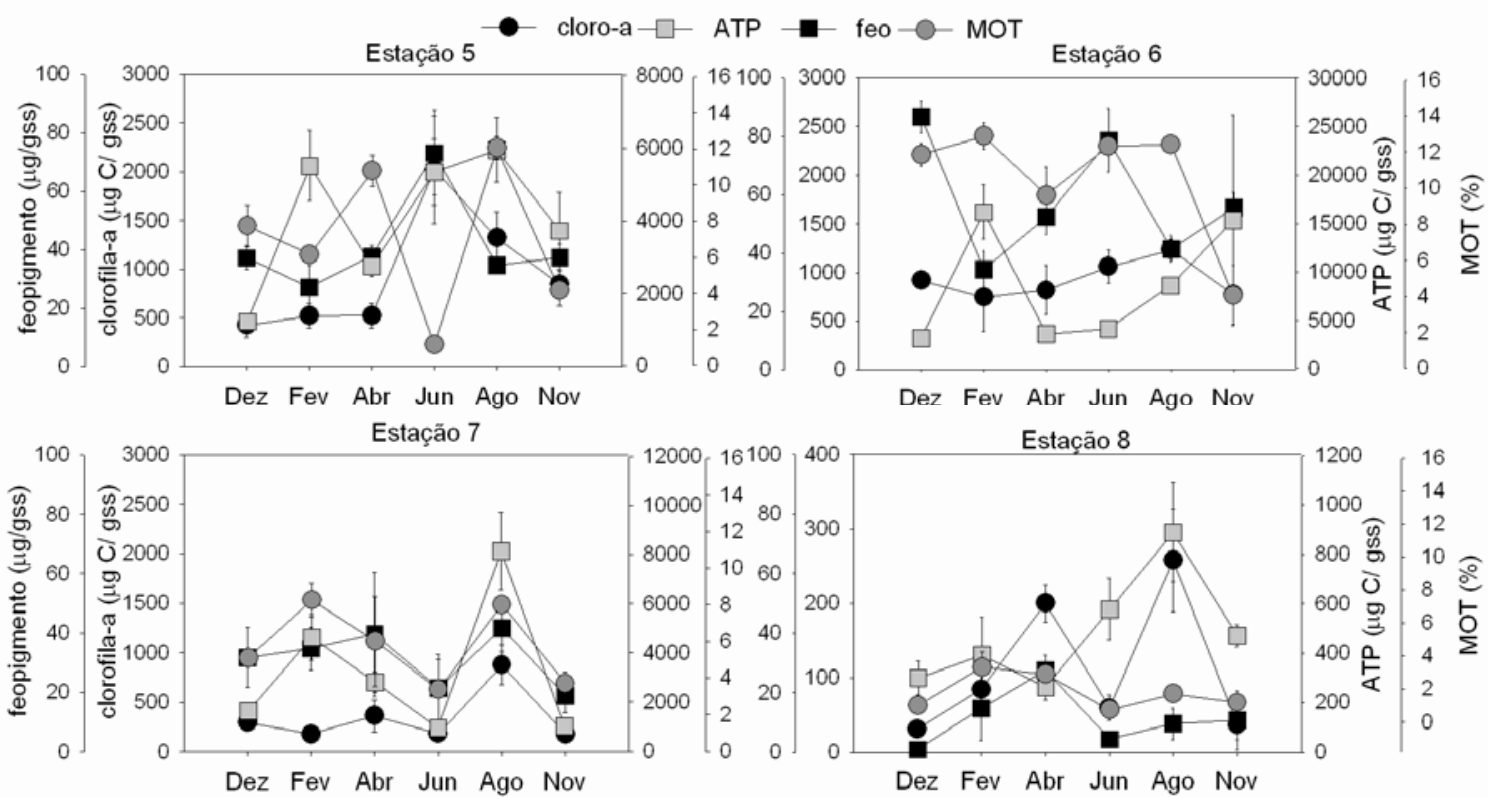

Figura 12: Valores médios integrados dos dados bióticos (MOT, clorofila-a, feopigmentos e ATP), da Enseada de Ubatuba (Estação 6 a 7) nos meses de coleta, barras verticais indicam o erro padrão. Fonte: Laboratório de Dinâmica Bêntica/IOUSP.

Tabela 7: Dados referentes à temperatura de fundo e porcentagem de sedimentos finos nas estações e meses de coleta. s.d.: sem dados.

\begin{tabular}{|c|c|c|c|c|c|c|}
\hline \multicolumn{7}{|c|}{ Temperatura de Fundo } \\
\hline & Dezembro & Fevereiro & Abril & Junho & Agosto & Novembro \\
\hline Estação 1 & 25,36 & 27,03 & 27,65 & 23,31 & 23,03 & 23,14 \\
\hline Estação 2 & 18,45 & 26,59 & 26,22 & 22,05 & 22,90 & 22,91 \\
\hline Estação 3 & 17,29 & 25,15 & 24,41 & 22,03 & 22,87 & 21,90 \\
\hline Estação 4 & 16,64 & 23,53 & 21,41 & 22,02 & 22,41 & 20,29 \\
\hline Estação 5 & 25,20 & 26,46 & 27,70 & 23,04 & 23,81 & 22,25 \\
\hline Estação 6 & 17,73 & 25,43 & 27,72 & 22,26 & 22,64 & 21,61 \\
\hline Estação 7 & 16,96 & 24,90 & 27,54 & 21,85 & 22,19 & 20,83 \\
\hline Estação 8 & 16,63 & 23,38 & 26,45 & 21,85 & 22,05 & 20,44 \\
\hline \multicolumn{7}{|c|}{$\%$ Finos } \\
\hline & Dezembro & Fevereiro & Abril & Junho & Agosto & Novembro \\
\hline Estação 1 & 17,56 & 8,47 & 12,37 & 28,22 & 25,83 & 18,77 \\
\hline Estação 2 & 52,03 & 59,50 & 47,36 & 52,21 & 49,08 & 71,88 \\
\hline Estação 3 & 70,42 & 43,77 & 48,96 & 42,19 & 41,93 & 53,19 \\
\hline Estação 4 & 83,99 & 77,21 & 83,61 & 78,32 & 79,65 & 81,20 \\
\hline Estação 5 & 68,44 & 72,56 & 83,58 & 83,37 & 81,92 & 82,52 \\
\hline Estação 6 & 93,92 & 95,38 & 90,71 & 96,47 & 88,70 & s.d. \\
\hline Estação 7 & 27,71 & 45,75 & 5,08 & 22,85 & 41,58 & 16,66 \\
\hline Estação 8 & 0,00 & 0,00 & 25,42 & 0,00 & 7,28 & 25,80 \\
\hline
\end{tabular}


Tabela 8: Resultados estatísticos do teste de correlação de Pearson referentes aos valores de densidade e biomassa bacteriana em relação aos dados complementares bióticos e abióticos $(n=24)$. T.F.: temperatura da água de fundo. Valores de $\mathrm{r}_{\text {(Pearson) }}$ em negrito apresentaram correlação significativa $(\mathrm{p}<0,05)$.

\begin{tabular}{ccccccccccccc}
\hline \hline & Dezembro & \multicolumn{3}{c}{ Fevereiro } & \multicolumn{3}{c}{ Abril } & \multicolumn{2}{c}{ Junho } & \multicolumn{2}{c}{ Agosto } \\
\hline & Densidade & Biomassa & Densidade & Biomassa & Densidade & Biomassa & Densidade & Biomassa & Densidade & Biomassa & Densidade & Biomassa \\
\hline cloro-a & $\mathbf{0 , 9 0 8}$ & $\mathbf{0 , 8 8 3}$ & 0,324 & 0,383 & $\mathbf{0 , 7 5 5}$ & $\mathbf{0 , 9 8 6}$ & $\mathbf{0 , 9 1 9}$ & $\mathbf{0 , 9 2 1}$ & $\mathbf{0 , 9 3 9}$ & $\mathbf{0 , 9 2 4}$ & $\mathbf{0 , 8 3 5}$ & $\mathbf{0 , 9 6 3}$ \\
MOT & $\mathbf{0 , 6 4 7}$ & $\mathbf{0 , 6 0 2}$ & $\mathbf{0 , 7 2 8}$ & $\mathbf{0 , 7 4 7}$ & $\mathbf{0 , 5 6 7}$ & $\mathbf{0 , 7 8 4}$ & $\mathbf{0 , 5 9 8}$ & $\mathbf{0 , 5 6 5}$ & $\mathbf{0 , 9 1 3}$ & $\mathbf{0 , 9 0 6}$ & 0,064 & 0,920 \\
feo & $\mathbf{0 , 7 3 8}$ & $\mathbf{0 , 6 9 3}$ & $\mathbf{0 , 4 9 9}$ & $\mathbf{0 , 4 4 6}$ & $\mathbf{0 , 6 4 3}$ & $\mathbf{0 , 5 4 8}$ & $\mathbf{0 , 7 7 3}$ & $\mathbf{0 , 6 8 7}$ & $\mathbf{0 , 6 0 0}$ & $\mathbf{0 , 5 8 7}$ & $\mathbf{0 , 6 8 3}$ & $\mathbf{0 , 0 7 9}$ \\
ATP & $\mathbf{0 , 8 8 7}$ & $\mathbf{0 , 8 8 8}$ & $\mathbf{0 , 4 8 2}$ & $\mathbf{0 , 5 0 4}$ & $\mathbf{0 , 5 3 1}$ & $\mathbf{0 , 6 4 3}$ & $\mathbf{0 , 6 3 9}$ & $\mathbf{0 , 7 0 6}$ & $\mathbf{0 , 7 9 4}$ & $\mathbf{0 , 7 8 0}$ & $\mathbf{0 , 5 3 1}$ & $\mathbf{0 , 7 8 1}$ \\
\% finos & 0,329 & 0,387 & 0,213 & 0,291 & 0,508 & 0,628 & 0,621 & 0,605 & 0,631 & 0,644 & $-0,009$ & 0,026 \\
T.F. & $-0,143$ & $-0,188$ & $-0,363$ & $-0,321$ & 0,410 & 0,561 & 0,249 & 0,199 & $\mathbf{0 , 4 5 3}$ & $\mathbf{0 , 4 3 6}$ & $-0,006$ & 0,530 \\
\hline \hline
\end{tabular}

Tabela 9: Resultados estatísticos do teste de correlação de Pearson referentes aos valores de densidade e biomassa bacterianas em relação aos dados complementares bióticos e abióticos $(\mathrm{n}=12)$, em cada enseada analisada separadamente. T.F.: temperatura da água de fundo. Valores de $\mathrm{r}_{(\text {Pearson })}$ em negrito apresentaram correlação significativa $(\mathrm{p}<0,05)$.

\begin{tabular}{|c|c|c|c|c|c|c|c|c|c|c|c|c|}
\hline Fortaleza & Dezembro & & Fevereiro & & Abril & & Junho & & Agosto & & Novembro & \\
\hline & Densidade & Biomassa & Densidade & Biomassa & Densidade & Biomassa & Densidade & Biomassa & Densidade & Biomassa & Densidade & Biomassa \\
\hline cloro-a & $-0,193$ & 0,085 & $-0,789$ & $-0,640$ & $-0,289$ & $-0,195$ & $-0,593$ & $-0,030$ & $-0,351$ & $-0,306$ & 0,720 & 0,556 \\
\hline MOT & 0,298 & 0,389 & 0,150 & $-0,066$ & 0,246 & 0,286 & 0,439 & 0,197 & $-0,262$ & $-0,513$ & 0,846 & 0,677 \\
\hline feo & 0,592 & 0,500 & 0,323 & 0,055 & 0,074 & 0,066 & 0,338 & $-0,538$ & $-0,318$ & $-0,507$ & 0,871 & 0,754 \\
\hline ATP & 0,107 & 0,237 & $-0,495$ & $-0,555$ & 0,619 & 0,596 & 0,152 & 0,167 & $-0,033$ & $-0,144$ & 0,361 & 0,292 \\
\hline$\%$ finos & 0,006 & 0,504 & 0,840 & 0,617 & 0,249 & 0,620 & 0,904 & $-0,154$ & $-0,114$ & $-0,791$ & 0,712 & 0,787 \\
\hline T.F. & $-0,249$ & $-0,410$ & $-0,792$ & $-0,735$ & 0,078 & 0,135 & $-0,577$ & 0,439 & 0,214 & 0,526 & 0,041 & $-0,112$ \\
\hline \multirow[t]{2}{*}{ Ubatuba } & Dezembro & & Fevereiro & & Abril & & Junho & & Agosto & & Novembro & \\
\hline & Densidade & Biomassa & Densidade & Biomassa & Densidade & Biomassa & Densidade & Biomassa & Densidade & Biomassa & Densidade & Biomassa \\
\hline cloro-a & 0,907 & 0,868 & 0,007 & 0,144 & 0,668 & 0,736 & 0,862 & 0,861 & 0,861 & 0,861 & 0,768 & 0,903 \\
\hline MOT & 0,860 & 0,796 & 0,544 & 0,631 & 0,450 & 0,472 & 0,738 & 0,617 & 0,617 & 0,617 & 0,228 & 0,313 \\
\hline feo & 0,944 & $\mathbf{0 , 8 8 7}$ & 0,137 & 0,077 & 0,595 & 0,621 & 0,752 & 0,616 & 0,616 & 0,616 & 0,667 & 0,848 \\
\hline ATP & 0,896 & 0,896 & 0,396 & 0,465 & 0,614 & 0,645 & 0,666 & 0,772 & 0,772 & 0,772 & 0,471 & 0,461 \\
\hline$\%$ finos & 0,808 & 0,770 & 0,152 & 0,346 & 0,697 & 0,838 & 0,942 & 0,966 & 0,971 & 0,988 & 0,365 & 0,398 \\
\hline T.F. & $-0,168$ & $-0,211$ & $-0,283$ & $-0,129$ & 0,489 & 0,497 & 0,530 & 0,687 & 0,687 & 0,687 & 0,620 & 0,756 \\
\hline
\end{tabular}


Dados normalizados para carbono orgânico total (COT) também foram tratados estatisticamente utilizando o teste de correlação de Pearson $(\mathrm{p}<0,05)$. Foram analisadas a densidade e biomassa bacteriana em relação à clorofila-a, MOT, ATP e feopigmentos, apenas da camada superficial do sedimento $(0-2 \mathrm{~cm})$ (Figuras 13 e 14) e temperatura da água de fundo (Tabela 7).

A variação espacial mostrou correlações variadas dependendo do mês de coleta. Em dezembro houve correlação positiva entre os dados bióticos e densidade e biomassa bacteriana, enquanto que em junho, agosto e novembro nenhuma correlação significativa foi encontrada (Tabela 10). Para cada enseada separadamente, correlações positivas foram encontradas entre densidade e biomassa bacteriana e MOT (dezembro, abril e junho) e também com temperatura de fundo (dezembro, junho e agosto) na Enseada de Fortaleza (Tabela 11). Na enseada de Ubatuba, correlações significativas foram observadas entre densidade e biomassa bacteriana e MOT e clorofila-a (dezembro e fevereiro) e com temperatura de fundo (fevereiro, junho, agosto e novembro) (Tabela 11).

Análises de correlação realizadas em cada estação de coleta só foram significativas entre a distribuição temporal dos dados bacterianos e os complementares $(p<0,05)$ na estação 6, onde densidade e biomassa bacteriana foram positivamente correlacionadas com a MOT, clorofila-a, ATP e feopigmentos $\left(\mathrm{r}_{\text {Pearson }}=0,834 ; 0,796 ; 0,782 ; 0,533\right.$; respectivamente), e negativamente com a temperatura de fundo $\left(\mathrm{r}_{\text {Pearson }}=-0,593\right)$.

Os dados de biomarcadores lipídicos referentes a fevereiro de 2005 (verão) e agosto de 2005 (inverno) da camada superficial do sedimento foram utilizados para análises de correlação com densidade e biomassa bacteriana. Para estas análises, foram utilizados dados de ácidos graxos poliinsaturados (AGP) referentes ao material fresco de origem fitoplanctônica, ácidos graxos ramificados (AGR) referentes a bactérias, ácidos graxos saturados de cadeia longa (AGCL) referentes a material de origem terrestre e ácidos graxos saturados de cadeia curta (AGCC), geralmente atribuídos a uma mistura de fontes autóctones (microalgas, zooplâncton, fauna bêntica e bactérias), normalizados para COT (Figura 15).

Os resultados das análises mostraram correlações significativas entre os valores de densidade e biomassa bacteriana e AGP ( $\mathrm{r}_{\text {Pearson }}=0,581$ e 0,524 , respectivamente) e AGR ( $\mathrm{r}$ 
Pearson $=0,532$ e 0,502 , respectivamente), e entre os valores de biomassa bacteriana e AGCC ( $\left.\mathrm{r}_{\text {Pearson }}=0,524\right)$. Não houve correlação entre densidade e biomassa de bactérias e AGCL.
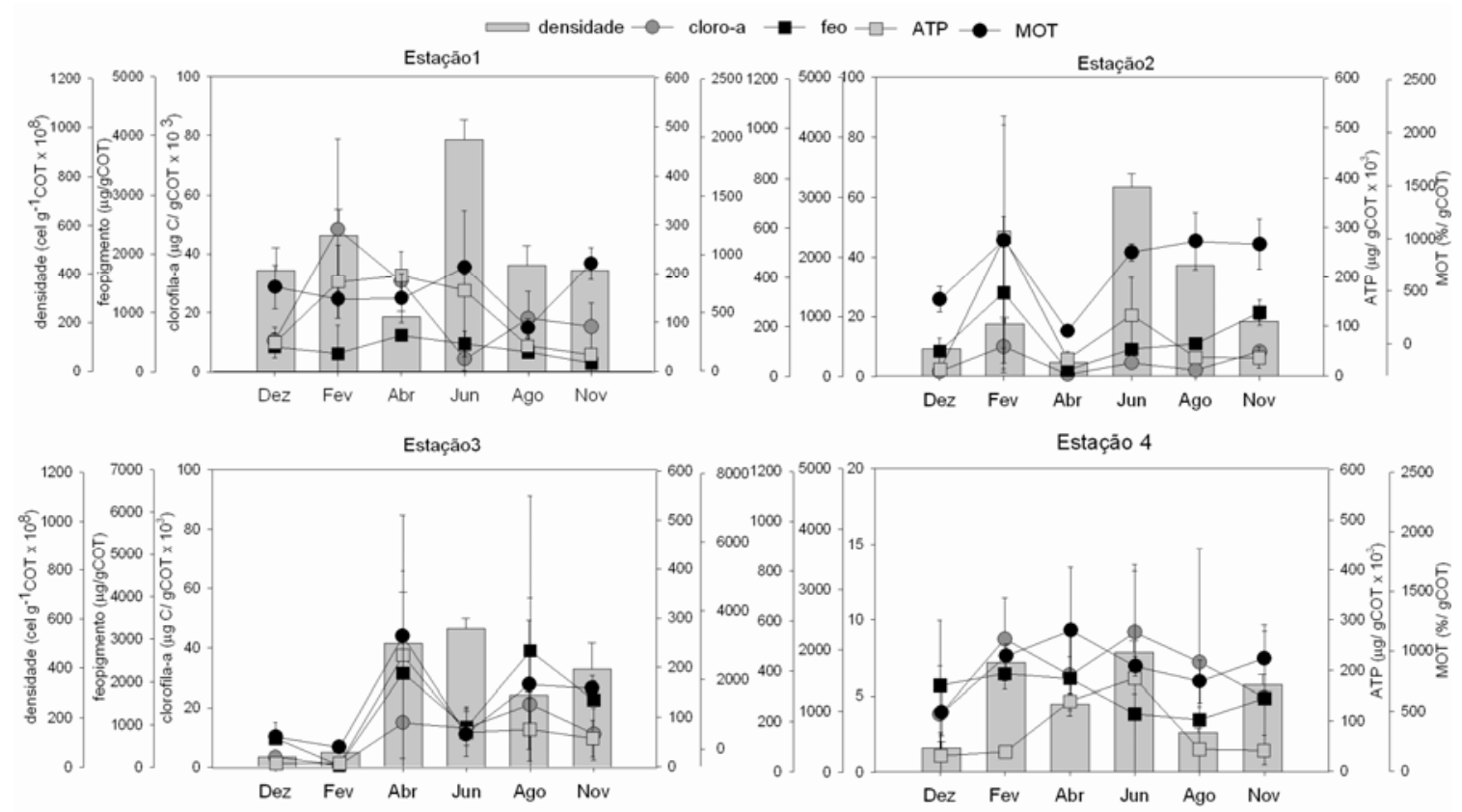

Figura 13: Dados bióticos (densidade bacteriana, MOT, clorofila-a, feopigmentos e ATP, normalizados para COT), da camada superficial do sedimento $(0-2 \mathrm{~cm})$ da Enseada de Fortaleza (Estação 1 a 4) nos meses de coleta .
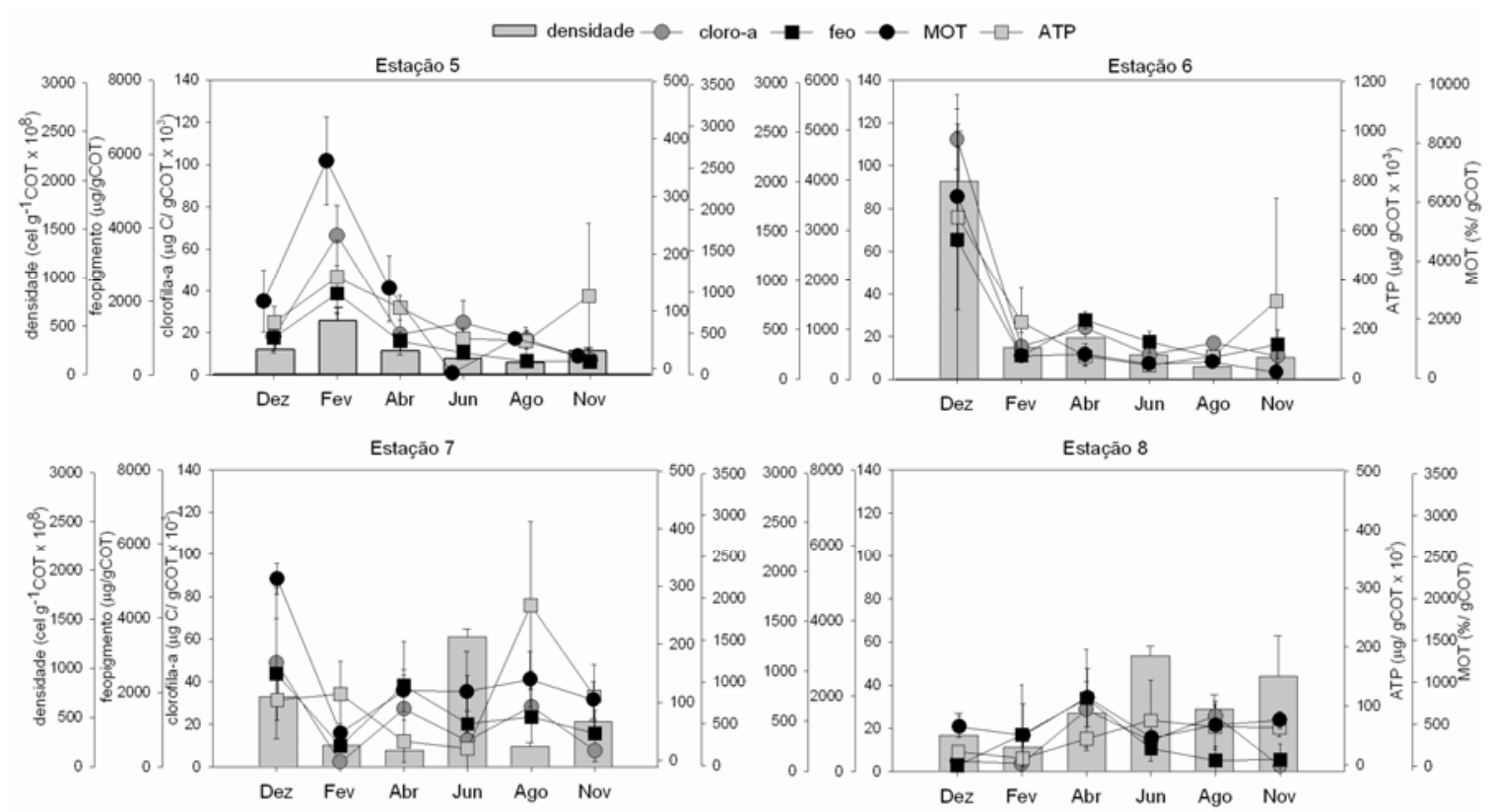

Figura 14: Dados bióticos (densidade bacteriana, MOT, clorofila-a, feopigmentos e ATP, normalizados para COT), da camada superficial do sedimento $(0-2 \mathrm{~cm})$ da Enseada de Ubatuba (Estação 5 a 8) nos meses de coleta 

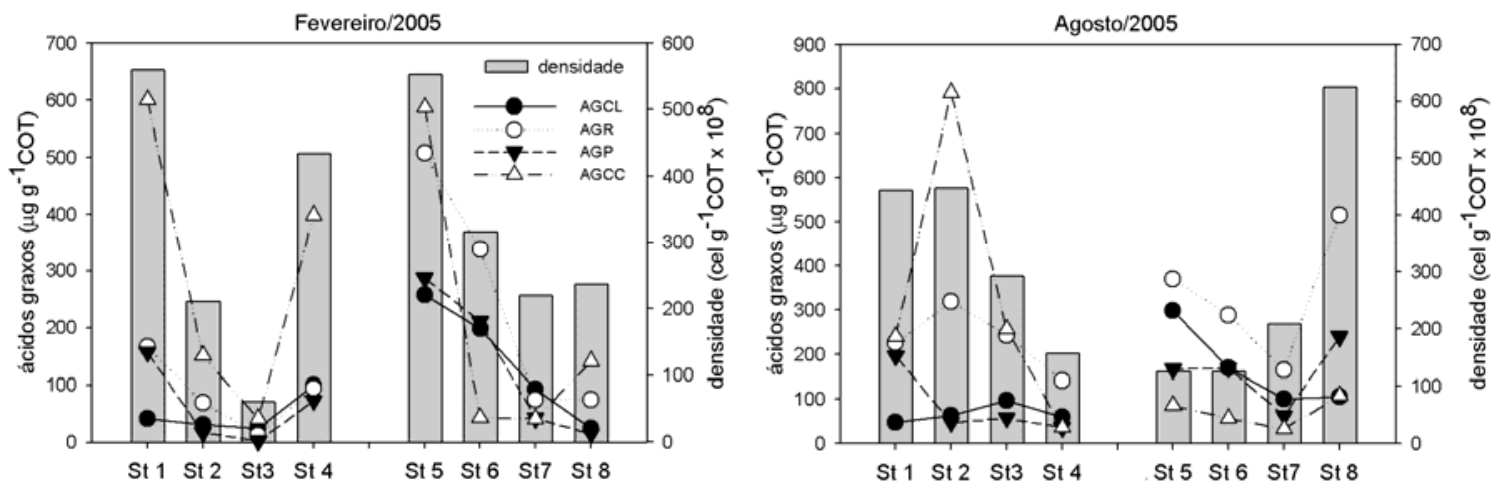

Figura 15: Valores da densidade bacteriana, e biomarcadores lipídicos referentes a produtores primários (AGP), bactéria (AGR) e plantas terrestres (AGCL) e referentes a fontes variadas (AGCC) em cada estação de coleta, no estrato de $0-2 \mathrm{~cm}$, no verão (fevereiro). Fonte dos dados de lipídios: Laboratório de Dinâmica Bêntica/IOUSP. 
Tabela 10: Resultados estatísticos do teste de correlação de Pearson dos valores de densidade e biomassa bacterianas em relação aos dados complementares bióticos referentes aos valores da camada superficial da coluna sedimentar $(0-2 \mathrm{~cm})$ (dados normalizados para COT) e a temperatura de fundo (T.F.) ( $n=24)$. Valores de $\mathrm{r}_{\text {(Perarson) }}$ em negrito obtiveram correlação significativa $(\mathrm{p}<0,05)$.

\begin{tabular}{cccccccccccccccc}
\hline \hline & Dezembro & \multicolumn{3}{c}{ Fevereiro } & \multicolumn{3}{c}{ Abril } & \multicolumn{3}{c}{ Junho } & \multicolumn{2}{c}{ Agosto } \\
\hline & Densidade & Biomassa & Densidade & Biomassa & Densidade & Biomassa & Densidade & Biomassa & Densidade & Biomassa & Densidade & Biomassa \\
\hline MOT & $\mathbf{0 , 8 9 7}$ & $\mathbf{0 , 8 3 2}$ & $\mathbf{0 , 5 0 3}$ & 0,365 & $\mathbf{0 , 5 0 9}$ & $\mathbf{0 , 6 8 5}$ & 0,398 & 0,319 & 0,024 & $-0,007$ & 0,005 & $-0,013$ \\
cloro- $a$ & $\mathbf{0 , 8 5 3}$ & $\mathbf{0 , 7 8 9}$ & $\mathbf{0 , 7 0 2}$ & $\mathbf{0 , 6 2 4}$ & 0,334 & 0,287 & $-0,282$ & $-0,277$ & $-0,136$ & $-0,131$ & $-0,322$ & $-0,190$ \\
feo & $\mathbf{0 , 8 4 0}$ & $\mathbf{0 , 7 7 1}$ & 0,267 & 0,047 & $\mathbf{0 , 4 7 7}$ & $\mathbf{0 , 5 4 4}$ & 0,122 & 0,042 & $-0,033$ & $-0,085$ & $-0,276$ & $-0,240$ \\
ATP & $\mathbf{0 , 9 3 3}$ & $\mathbf{0 , 9 5 6}$ & 0,262 & 0,271 & 0,215 & 0,306 & $-0,038$ & 0,038 & 0,185 & $-0,059$ & $-0,023$ & 0,025 \\
T.F. & $-0,117$ & $-0,112$ & 0,326 & 0,417 & $-0,109$ & $-0,156$ & $-0,318$ & $-0,318$ & $-0,010$ & $-0,006$ & $-0,284$ & $-0,113$ \\
\hline \hline
\end{tabular}

Tabela 11: Resultados estatísticos do teste de correlação de Pearson dos valores de densidade e biomassa bacterianas em relação aos dados complementares bióticos referentes aos valores da camada superficial da coluna sedimentar $(0-2 \mathrm{~cm})$ (dados normalizados para COT) e a temperatura de fundo (T.F.) ( $\mathrm{n}=12)$, em cada enseada separadamente. Valores de $\mathrm{r}_{\text {(Perarson) }}$ em negrito obtiveram correlação significativa $(\mathrm{p}<0,05)$.

\begin{tabular}{|c|c|c|c|c|c|c|c|c|c|c|c|c|}
\hline Fortaleza & Dezembro & & Fevereiro & & Abril & & Junho & & Agosto & & Novembro & \\
\hline & Densidade & Biomassa & Densidade & Biomassa & Densidade & Biomassa & Densidade & Biomassa & Densidade & Biomassa & Densidade & Biomassa \\
\hline MOT & 0,716 & 0,780 & 0,284 & 0,056 & 0,806 & 0,859 & 0,866 & 0,848 & $-0,128$ & $-0,155$ & 0,157 & 0,090 \\
\hline cloro-a & 0,746 & 0,749 & 0,525 & 0,467 & 0,393 & 0,379 & $-0,565$ & $-0,529$ & $-0,098$ & $-0,148$ & 0,066 & $-0,027$ \\
\hline feo & $-0,268$ & $-0,212$ & 0,125 & $-0,158$ & 0,784 & 0,826 & $-0,274$ & $-0,189$ & $-0,192$ & $-0,215$ & $-0,291$ & $-0,224$ \\
\hline ATP & 0,731 & 0,801 & 0,233 & 0,156 & 0,735 & 0,634 & 0,017 & 0,244 & $-0,101$ & $-0,130$ & 0,226 & 0,655 \\
\hline T.F. & 0,953 & 0,870 & 0,105 & 0,216 & $-0,301$ & $-0,279$ & 0,800 & 0,805 & 0,811 & 0,741 & $-0,109$ & $-0,134$ \\
\hline \multirow[t]{2}{*}{ Ubatuba } & Dezembro & & Fevereiro & & Abril & & Junho & & Agosto & & Novembro & \\
\hline & Densidade & Biomassa & Densidade & Biomassa & Densidade & Biomassa & Densidade & Biomassa & Densidade & Biomassa & Densidade & Biomassa \\
\hline MOT & 0,873 & 0,785 & 0,769 & 0,722 & $-0,131$ & 0,090 & 0,284 & 0,186 & $-0,010$ & $-0,064$ & 0,376 & 0,381 \\
\hline cloro-a & 0,806 & 0,721 & 0,947 & 0,872 & 0,070 & 0,026 & $-0,307$ & $-0,315$ & 0,443 & 0,360 & $-0,532$ & $-0,474$ \\
\hline feo & 0,838 & 0,743 & 0,454 & 0,331 & $-0,052$ & $-0,094$ & 0,199 & 0,083 & $-0,107$ & $-0,190$ & $-0,404$ & $-0,322$ \\
\hline ATP & 0,938 & 0,958 & 0,319 & 0,510 & $-0,148$ & $-0,087$ & $-0,114$ & $-0,048$ & $-0,123$ & $-0,205$ & $-0,276$ & $-0,345$ \\
\hline T.F. & $-0,352$ & $-0,322$ & 0,743 & 0,828 & $-0,711$ & $-0,439$ & $-0,843$ & $-0,810$ & $-0,596$ & $-0,407$ & $-0,743$ & $-0,755$ \\
\hline
\end{tabular}


Além disto, foram realizados testes de correlação entre densidade bacteriana e densidade de macro- e meiofauna (Figura 16), não sendo encontrada correlação significativa em nenhum mês de estudo ou estação de coleta.

A qualidade da matéria orgânica foi definida, neste estudo, como a proporção das concentrações de materiais ricos em nutrientes (e.g. clorofila-a) e materiais orgânicos degradados (e.g. feopigmentos). Portanto, as concentrações de clorofila-a só representam uma fonte alimentar de alta qualidade se a quantidade de feopigmentos for relativamente baixa. Outra medida de qualidade utilizada foi a razão de carbono e nitrogênio orgânicos medidos no sedimento. Compostos mais lábeis possuem baixas razões $\mathrm{C} / \mathrm{N}$. Os resultados das razões cloro/feo e C/N estão apresentados na Tabela 12.
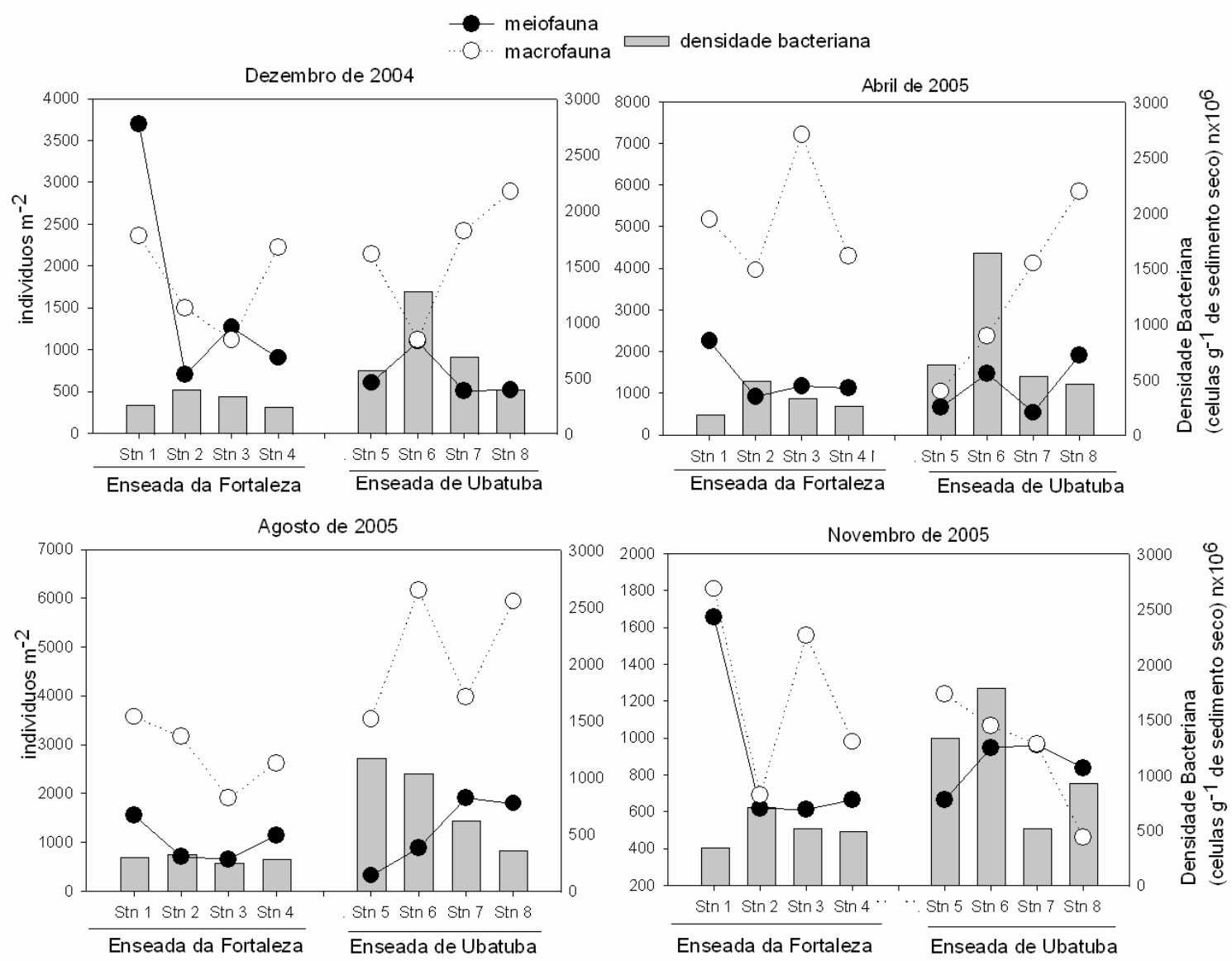

Figura 16: Valores integrados de densidade bacteriana, meiofauna e macrofauna encontrados em cada estação nos meses de coleta. Fonte dos valores de meio- e macrofauna: C.O. Quintana, comunicação pessoal. 
Tabela 12: Razão clorofila-a/feopigmento da coluna sedimentar $(10 \mathrm{~cm})$ de cada estação de coleta em cada mês de estudo, e valores de razão $\mathrm{C} / \mathrm{N}$ da camada superficial $(0-2 \mathrm{~cm})$ da coluna sedimentar em cada estação e mês de coleta.

\begin{tabular}{ccccccc}
\hline \hline cloro/feo & Dezembro & Fevereiro & Abril & Junho & Agosto & Novembro \\
Estação 1 & 1,39 & 3,57 & 1,42 & 1,75 & 0,68 & 0,62 \\
Estação 2 & 0,12 & 0,19 & 0,13 & 0,21 & 0,12 & 0,16 \\
Estação 3 & 0,10 & 0,22 & 0,10 & 0,16 & 0,19 & 0,10 \\
Estação 4 & 0,08 & 0,18 & 0,06 & 0,21 & 0,15 & 0,15 \\
Estação 5 & 0,28 & 0,48 & 0,35 & 0,69 & 0,95 & 0,57 \\
Estação 6 & 0,27 & 0,54 & 0,39 & 0,34 & 0,75 & 0,35 \\
Estação 7 & 0,23 & 0,13 & 0,23 & 0,21 & 0,52 & 0,24 \\
Estação 8 & 0,79 & 0,14 & 0,18 & 0,34 & 0,67 & 0,09 \\
\hline \hline C/N & Dezembro & Fevereiro & Abril & Junho & Agosto & Novembro \\
Estação 1 & 6,21 & $*$ & 11,33 & $*$ & $*$ & $*$ \\
Estação 2 & 6,61 & 5,88 & 10,62 & 10,46 & $*$ & 12,56 \\
Estação 3 & 9,11 & 10,12 & 12,76 & 11,29 & $*$ & 9,02 \\
Estação 4 & 8,02 & 9,24 & 15,32 & 16,88 & 10,66 & 11,28 \\
Estação 5 & 6,88 & $*$ & 12,02 & 12,87 & 11,08 & 10,36 \\
Estação 6 & 7,37 & 9,25 & 9,92 & 12,80 & 11,23 & 11,07 \\
Estação 7 & 9,28 & 10,09 & 10,42 & $*$ & 9,80 & 15,37 \\
Estação 8 & 10,94 & 9,33 & 11,79 & $*$ & 9,57 & $*$ \\
\hline \hline
\end{tabular}

*Valores de $\mathrm{N}$ foram menores que 0,01 .

\subsection{Análises de componentes principais (ACP).}

A ACP foi realizada utilizando-se os valores integrados de biomassa bacteriana da coluna sedimentar $(0-10 \mathrm{~cm})$, os valores complementares bióticos (ATP, clorofila-a e MOT) e valores abióticos (temperatura de fundo, porcentagem de sedimentos finos e porcentagem de areia). Foram realizadas três análises separadas, de todas as estações de coleta ( 1 a 8 ) em todos os meses, e de cada enseada separadamente (Fortaleza e Ubatuba), em todos os períodos.

A ACP realizada com todas as estações de coleta (Figura 17) explicou 65\% da variação dos dados. O Eixo 1 explicou $48 \%$ da variação dos dados e apresentou valores negativos apenas para porcentagem de areia. Valores positivos foram encontrados para todos os outros fatores. Já o Eixo 2 explicou 17\% da variação dos dados, com valores positivos para clorofila, ATP, porcentagem de areia e temperatura de fundo, e negativos para biomassa bacteriana e feopigmentos. Nesta análise foi possível observar a separação de três grupos principais: A, formado pelas estações 1 e 8 , sendo principalmente influenciadas pela grande quantidade de areia nestas regiões, com valores altamente 
negativos para o Eixo 1; B, formado principalmente pelas estações 7, 2, 3 e 4, caracterizado por não apresentar grande influência de uma variável específica, sendo influenciado pela maior parte dos fatores igualmente; $\mathrm{C}$, formado pelas estações 5 e 6 , caracterizou-se por altos valores de MOT, clorofila e feopigmento, também apresentando os maiores valores de biomassa bacteriana e ATP, o que confirmou a grande influência de altos valores de matéria orgânica nestas estações.

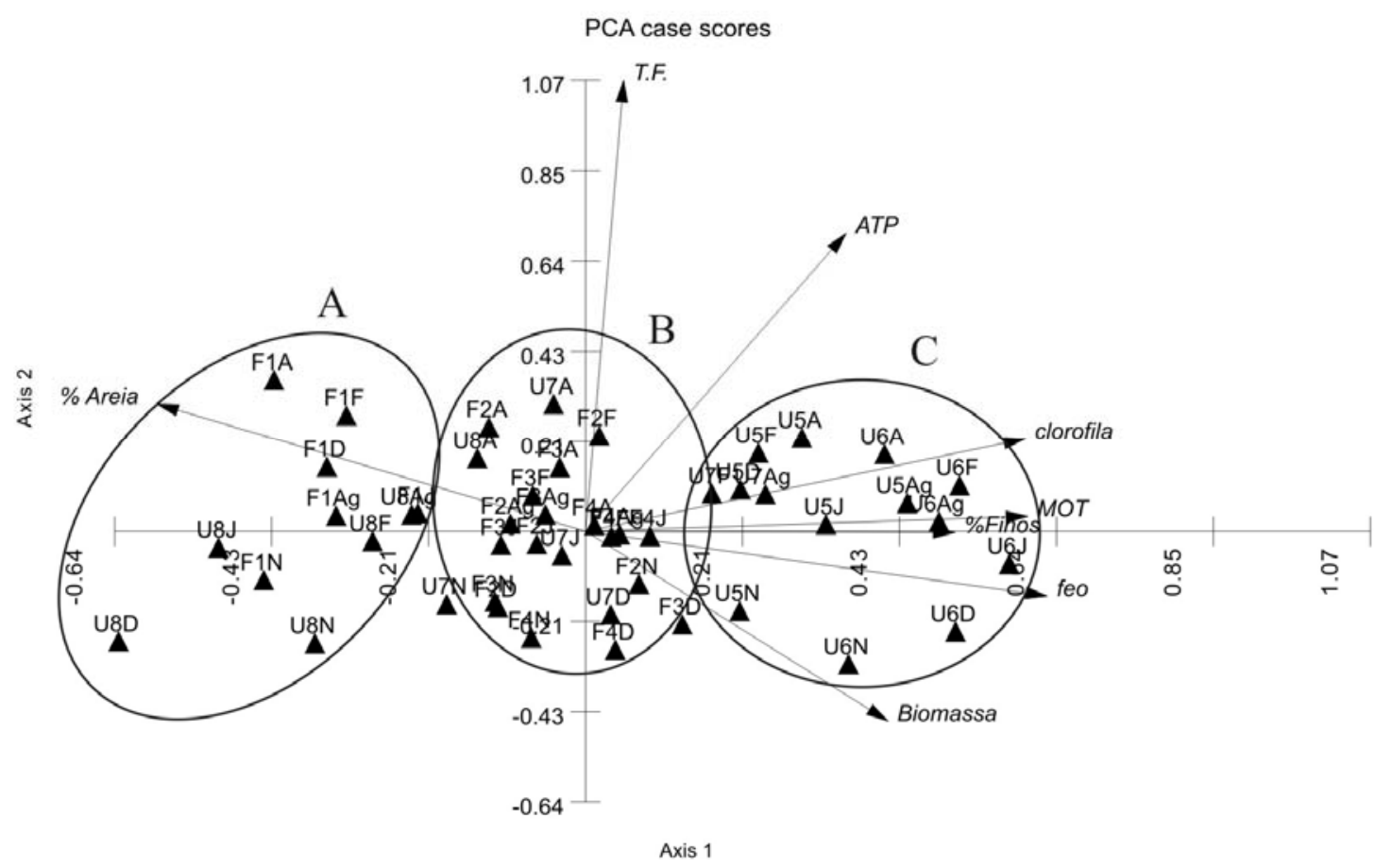

Vector scaling: 1.41

Figura 17: Resultado gráfico da ACP das estações de coleta em cada mês (scores) em relação às variáveis medidas. F1 a $4=$ enseada de Fortaleza; U5 a $8=$ enseada de Ubatuba; $\mathrm{D}=$ dezembro/2004; $\mathrm{F}=$ fevereiro/2005; $\mathrm{A}=$ abril/2005; $\mathrm{J}=$ junho/2005; $\mathrm{Ag}=\operatorname{agosto} / 2005 ; \mathrm{N}=$ novembro/2005. Três principais grupos formados: A, B, C.

As enseadas foram analisadas separadamente devido à grande diferença encontrada entre os fatores tanto bióticos quando abióticos entre as enseadas. A ACP realizada na enseada de Fortaleza (Figura 18) explicou 66\% da variação dos dados. O Eixo 1 explicou $49 \%$ da variação dos dados apresentando valores positivos para porcentagem de areia e T.F., e valores negativos para biomassa bacteriana, MOT, porcentagem de finos e feopigmentos. O Eixo 2 explicou 17\% da variação, com valores positivos para clorofila-a e ATP. Foi observado a formação de três grupos bem definidos: A, formado pela estação 4 e meses de dezembro e novembro das estações 2 e 3, caracterizando-se por altos valores de 
matéria orgânica e de feopigmento; $\mathrm{B}$, formado pelas estações 2 e 3 nos meses de fevereiro, agosto e abril, sendo caracterizado por contribuições intermediárias dos fatores; C, formado pela estação 1 , caracterizado principalmente por altos valores de areia na sua composição granulométrica.

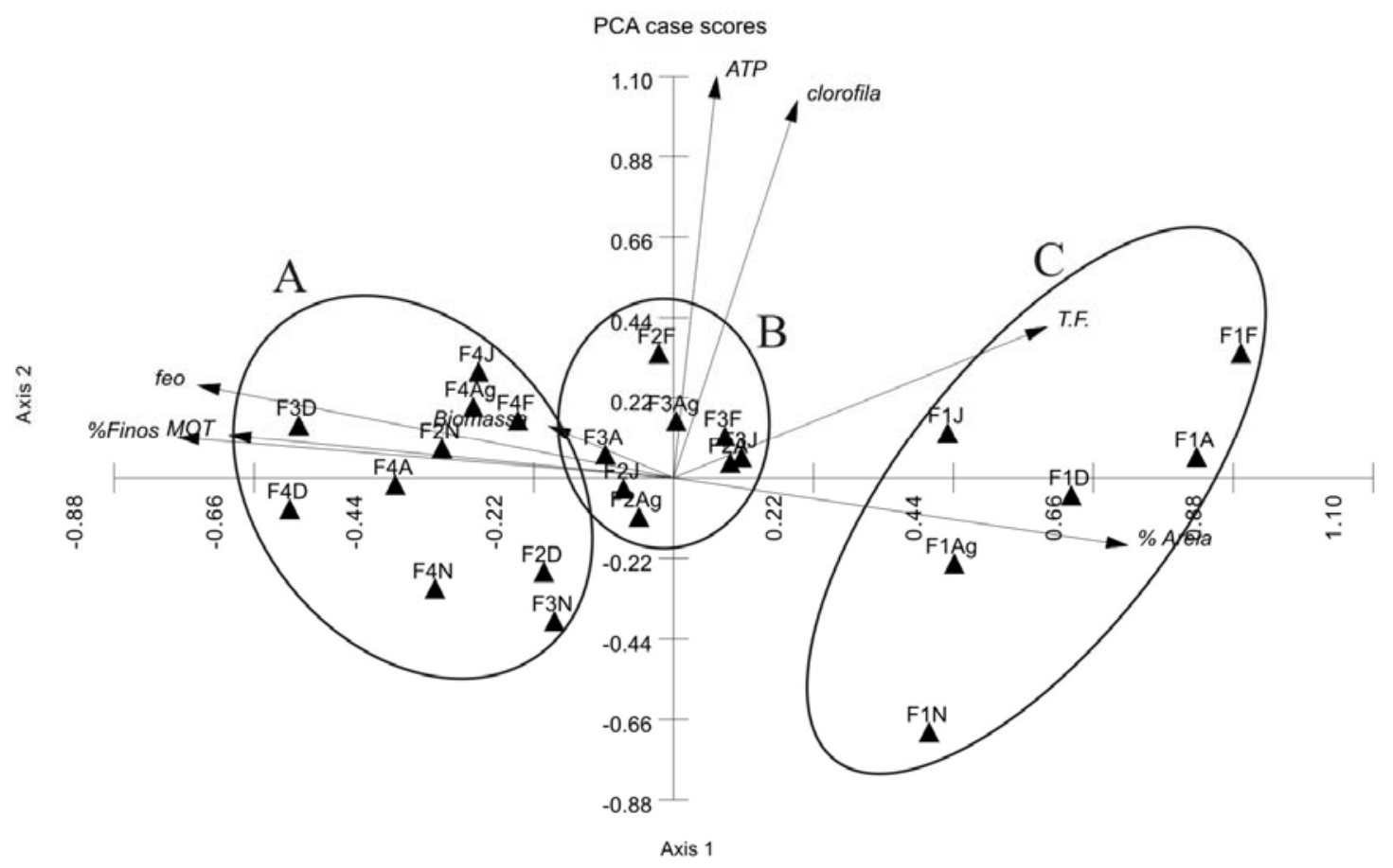

Vector scaling: 1.61

Figura 18: Resultado gráfico da ACP para estações de coleta em cada mês (scores) na enseada de Fortaleza em relação às variáveis medidas. $\mathrm{D}=$ dezembro/2004; $\mathrm{F}=$ fevereiro/2005; $\mathrm{A}=$ abril/2005; $\mathrm{J}=$ junho/2005; $\mathrm{Ag}=$ agosto/2005; $\mathrm{N}=$ novembro/2005. Três principais grupos formados: A, B, C.

A ACP realizada na enseada de Ubatuba (Figura 19) explicou 72,5\% da variação dos dados. O Eixo 1 explicou 55,7\% da variação apresentando valores positivos para todas as variáveis com exceção de porcentagem de areia, que apresentou valores negativos para este Eixo. O Eixo 2 explicou 16,7\% da variação dos dados, com valores positivos para temperatura, ATP e porcentagem de areia, e valores negativos para biomassa bacteriana. Foi observada a formação de dois grupos distintos na análise realizada: A, formado pelas estações 7 e 8, caracterizado por altos valores de areia e baixos teores de matéria orgânica e biomassa bacteriana; B, formado pelas estações 5 e 6 , sendo caracterizado por altos valores 
de matéria orgânica clorofila-a e feopigmentos e por maiores valores de biomassa bacteriana.

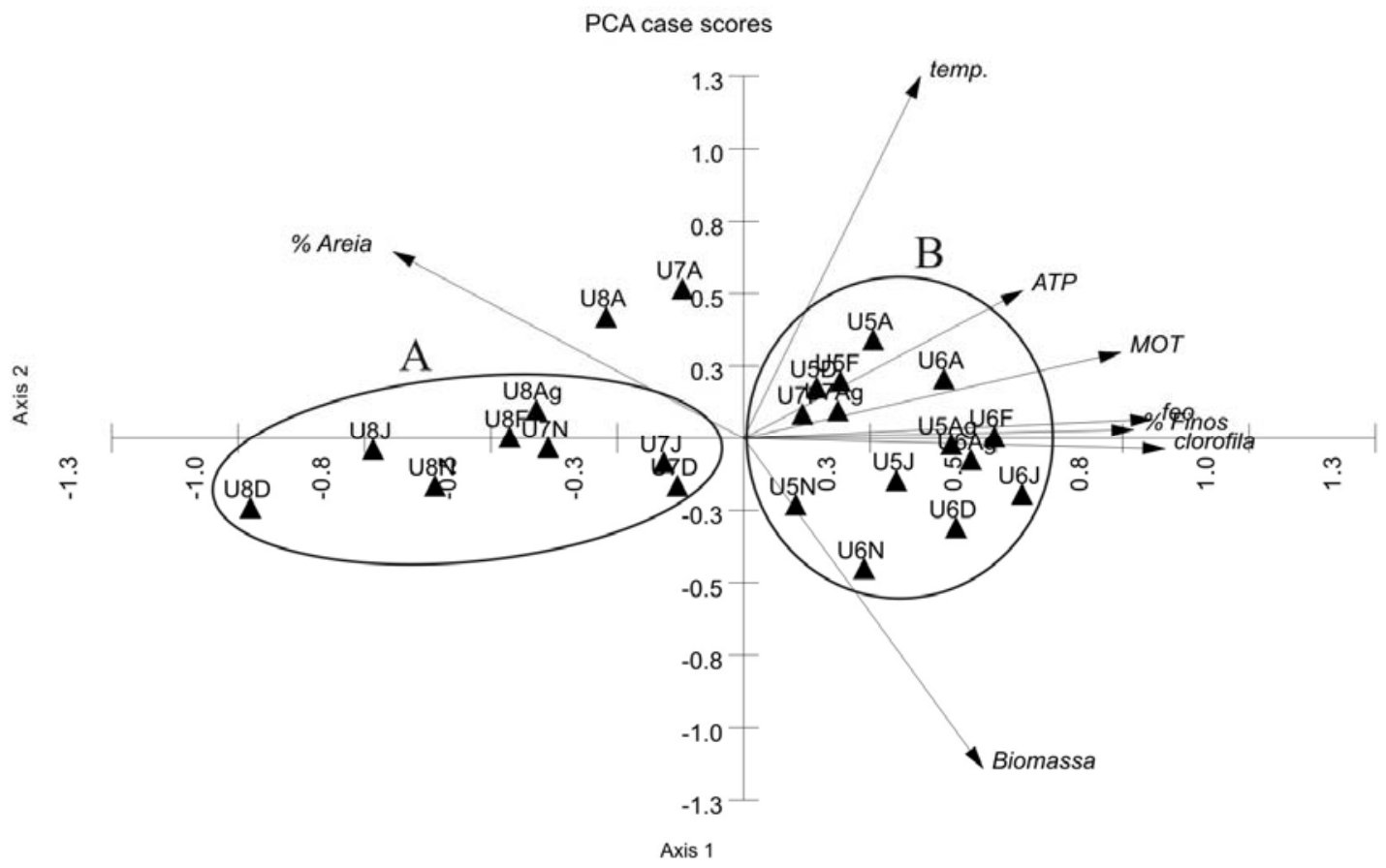

Vector scaling: 1.99

Figura 19: Resultado gráfico da ACP para os inventários da coluna sedimentar nas estações de coleta em cada mês (scores) na enseada de Ubatuba em relação às variáveis medidas. $\mathrm{D}$ $=$ dezembro/2004; $\mathrm{F}=$ fevereiro/2005; $\mathrm{A}=$ abril/2005; $\mathrm{J}=$ junho/2005; $\mathrm{Ag}=$ agosto/2005; $\mathrm{N}=$ novembro/2005. Dois principais grupos formados: A e B.

\subsection{Normalizações}

Devido à marcada diferença dos parâmetros físicos entre as duas enseadas, principalmente quanto à granulometria, os dados referentes à densidade e biomassa bacteriana foram normalizados quanto a diferentes dimensões de escala. Os valores integrados foram normalizados quanto à porosidade e dados de conteúdo de água.

Em dezembro de 2004, os dados normalizados para porosidade e sedimento seco mantiveram o mesmo padrão de distribuição entre as enseadas. Já os dados normalizados para o conteúdo de água apresentaram distribuição diferente, com valores entre as enseadas menos discrepantes e um grande aumento dos valores na estação 8 (Figura 20).

Em fevereiro de 2005, houve mudanças nos padrões de distribuição de densidade e biomassa nas estações, com variações diferentes dependendo da normalização utilizada nos 
dados. Neste caso, os valores normalizados para porosidade e água foram mais parecidos, porém diferentes dos dados normalizados para sedimento seco (Figura 21). Em abril de 2005, não foram observadas grandes diferenças na distribuição da densidade e biomassa bacteriana entre as estações relacionadas às diferentes normalizações (Figura 22), apenas a estação 8 novamente mostrou um aumento nos valores quando normalizados para conteúdo de água do sedimento.
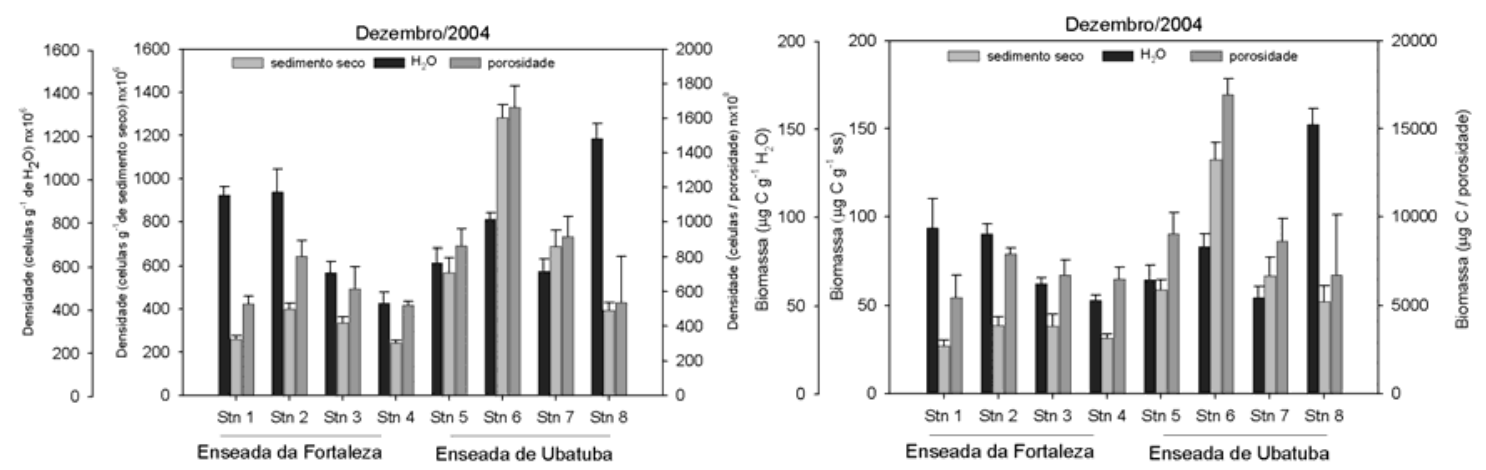

Figura 20: Resultados de densidade (esquerda) e biomassa (direita) bacterianas normalizados para g sedimento seco, conteúdo de água e porosidade referentes a dezembro/2004, nas estações de coleta (linhas verticais indicam o erro padrão).
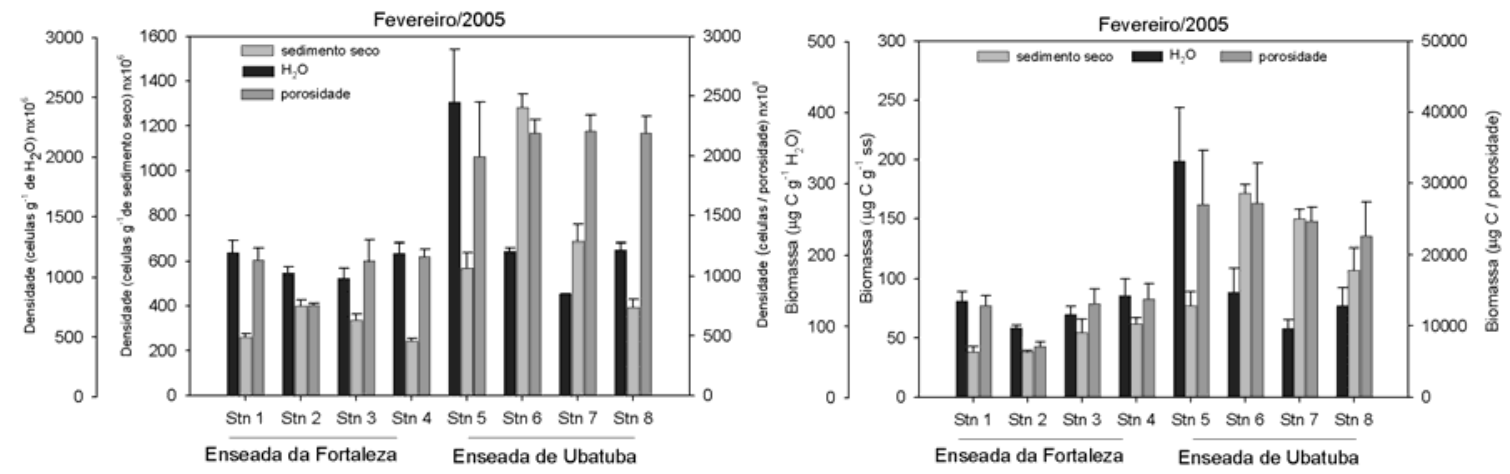

Figura 21: Resultados de densidade (esquerda) e biomassa (direita) bacterianas normalizados para g sedimento seco, conteúdo de água e porosidade referentes a fevereiro de 2005 , nas estações de coleta (linhas verticais indicam o erro padrão). 

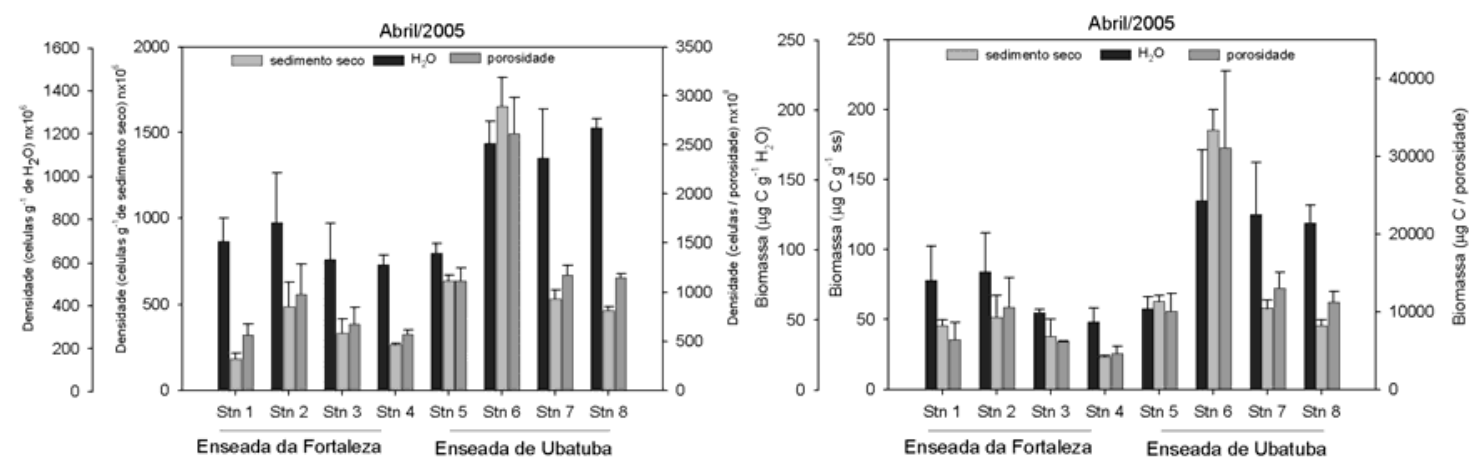

Figura 22: Resultados de densidade (esquerda) e biomassa (direita) bacterianas normalizados para g sedimento seco, conteúdo de água e porosidade referentes a abril de 2005, nas estações de coleta (linhas verticais indicam o erro padrão).

Os dados normalizados de junho de 2005 não variaram muito entre as estações, independentemente da normalização utilizada (Figura 23). Apenas as estações 7 e 8 apresentaram altos valores apenas quando normalizados para conteúdo de água. Em agosto de 2005 não foi encontrada grande variação na distribuição de densidade e biomassa entre as estações devido a normalizações. Apenas a estação 8 mostrou um grande aumento nos valores de densidade e biomassa quando normalizados para o conteúdo de água e porosidade (Figura 24). Em novembro de 2005, os dados normalizados para conteúdo de água mostraram padrões diferentes dos normalizados para porosidade e sedimento seco (Figura 25).
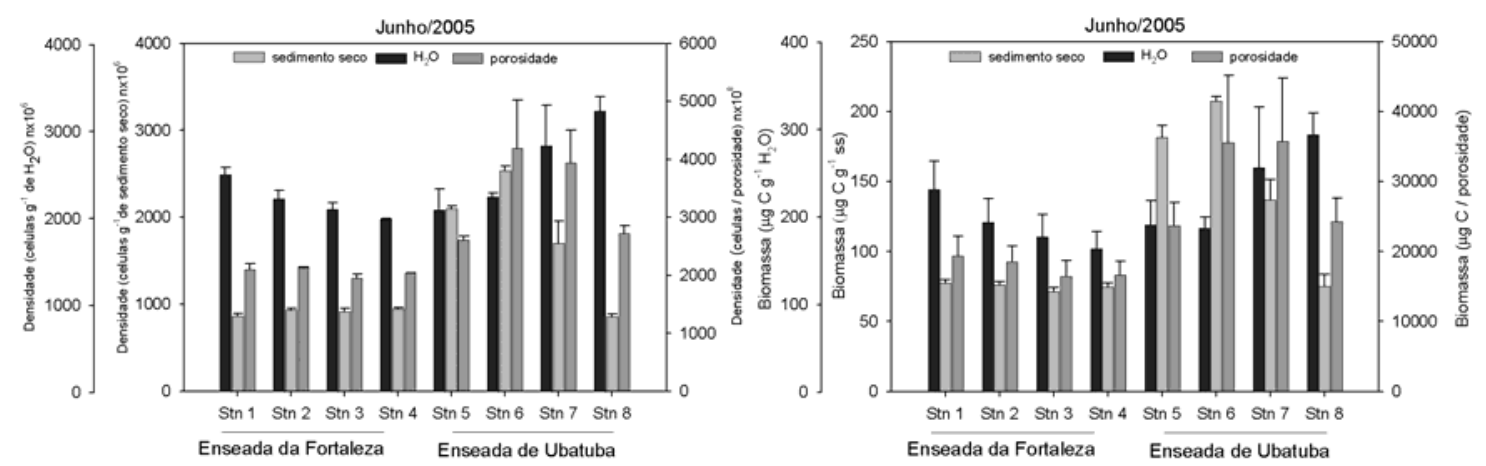

Figura 23: Resultados de densidade (esquerda) e biomassa (direita) bacterianas normalizados para g sedimento seco, conteúdo de água e porosidade referentes a junho de 2005, nas estações de coleta (linhas verticais indicam o erro padrão). 

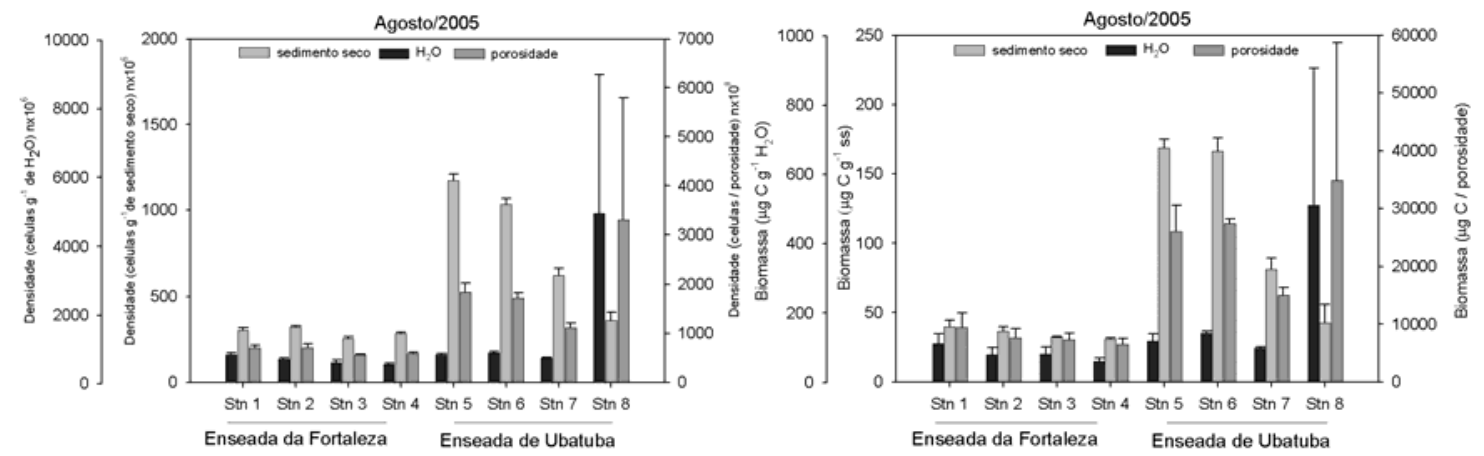

Figura 24: Resultados de densidade (esquerda) e biomassa (direita) bacterianas normalizados para g sedimento seco, conteúdo de água e porosidade referentes a agosto de 2005 , nas estações de coleta (linhas verticais indicam o erro padrão).
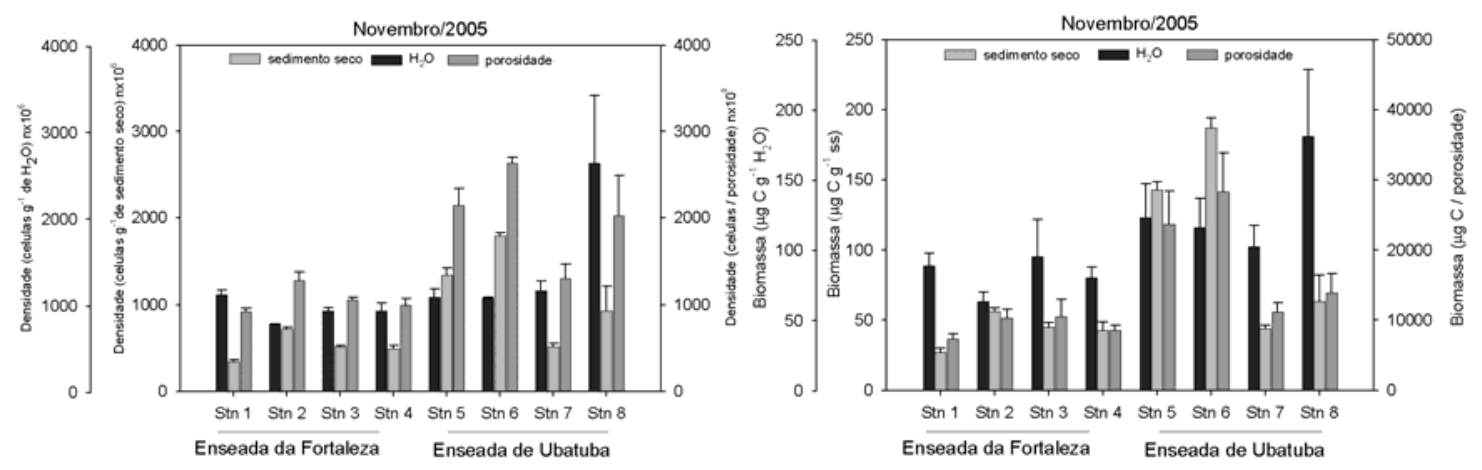

Figura 25: Resultados de densidade (esquerda) e biomassa (direita) bacterianas normalizados para g sedimento seco, conteúdo de água e porosidade referentes a novembro de /2005, nas estações de coleta (linhas verticais indicam o erro padrão).

\subsection{Balanço de carbono orgânico nas comunidades microbianas.}

O balanço de carbono na camada superficial do sedimento $(0-2 \mathrm{~cm})$ foi obtido através de estimativas de carbono para diferentes técnicas analíticas. A comunidade microbiana medida por valores de ATP contribuiu com os maiores valores de CO na comunidade em todas as estações e meses de coleta (Tabela 13) com valores variando de 0,61 a $65 \%$ do COT. Valores de contribuição de CO provenientes dos dados de clorofila-a foram muito pequenos, variando de 0,08 a $11 \%$ (Tabela 13). Os valores de CO provenientes de biomassa bacteriana no COT foram muito baixos, não passando de 2,6\% e, na maioria das amostras, contribuindo com menos de $1 \%$ do COT (Tabela 13). Em média maiores contribuições de bactérias, produtores primários e microorganismos (ATP) para o COT 
foram encontrados na enseada de Ubatuba $(0,33,1,71$ e $11,25 \%$, respectivamente) quando comparados à enseada de Fortaleza (0,24, 0,63 e 5,25\% respectivamente).

A contribuição de cada parcela da comunidade microbiana para o $\mathrm{CO}$ encontrado nos sedimentos superficiais da região variou dependendo da estação e mês de coleta. Em dezembro de 2004, observaram-se baixos valores dos pools de CO em relação aos outros meses (Figura 29). Neste mês, destacou-se a alta contribuição relativa de $\mathrm{CO}$ derivado de organismos fotoautotróficos na comunidade microbiana na estação 3 (Figura 26). Altas contribuições da biomassa bacteriana em relação à de clorofila-a foram observadas nas estações 1 e 2 e na estação 8 , onde a contribuição bacteriana foi maior do que a baseada em medidas de clorofila-a (Figura 26).

Em fevereiro de 2005, maiores valores de CO estimados através de medidas de ATP, principalmente nas estações 6 e 7, foram registrados. Além disso, houve contribuições relativamente baixas de bactérias e clorofila-a em todas as estações (Figura 26). A biomassa bacteriana apresentou maiores valores relativos do que clorofila-a nas estações 3 e 7 e valores muito próximos nas estações 4 e 8 no mesmo mês (Figura 26). No mês de abril de 2005, podemos destacar a alta contribuição relativa de CO derivado de clorofila-a na estação 8 e principalmente na estação 7. Valores derivados de biomassa bacteriana foram relativamente baixos em todas as estações de estudo. Altos valores de ATP nas estações 4, 5 e 6 , e altas contribuições de biomassa bacteriana foram observadas nas estações 2 e 7 em junho. Neste período, a estação 5 apresentou altos valores relativos de clorofila-a (Figura 26). Em agosto de 2005, todas as estações mostraram maiores contribuições relativas à ATP, seguida de clorofila-a e bactéria, com os maiores valores observados na estação 6. O mesmo ocorreu em novembro de 2005 (Figura 26). 
Tabela 13: Porcentagem de contribuição de CO pela comunidade microbiana (ATP), produtores primários (clorofila-a) e biomassa bacteriana para o pool de COT em cada estação e mês de coleta. Todos os valores usados em $\mu \mathrm{g} \mathrm{C} / \mathrm{g}$ sedimento seco.

\begin{tabular}{cccccccccc}
\hline \hline & $\begin{array}{c}\text { Dezembro } \\
\text { bactéria }\end{array}$ & cloro-a & ATP & $\begin{array}{c}\text { Fevereiro } \\
\text { bactéria }\end{array}$ & cloro-a & ATP & $\begin{array}{c}\text { Abril } \\
\text { bactéria }\end{array}$ & cloro-a & ATP \\
\hline Est.1 & 0,53 & 1,05 & 5,86 & 0,83 & 4,84 & 18,32 & 0,26 & 3,07 & 19,57 \\
Est.2 & 0,12 & 0,17 & 1,27 & 0,23 & 1,00 & 28,01 & 0,06 & 0,08 & 3,33 \\
Est.3 & 0,05 & 0,35 & 0,61 & 0,08 & 0,07 & 0,67 & 0,80 & 1,50 & 22,43 \\
Est.4 & 0,15 & 0,38 & 3,10 & 0,59 & 0,87 & 3,94 & 0,37 & 0,64 & 13,90 \\
Est.5 & 0,31 & 1,83 & 8,02 & 0,72 & 6,63 & 15,95 & 0,30 & 1,92 & 10,55 \\
Est.6 & 2,59 & 11,24 & 65,24 & 0,54 & 1,55 & 22,78 & 0,61 & 2,41 & 8,89 \\
Est.7 & 0,74 & 4,90 & 10,37 & 0,31 & 0,24 & 11,44 & 0,21 & 2,74 & 3,29 \\
Est.8 & 0,54 & 0,48 & 2,26 & 0,27 & 0,37 & 1,07 & 0,64 & 2,88 & 4,48 \\
\hline & Junho & & & Agosto & & & Novembro & & \\
& bactéria & cloro-a & ATP & bactéria & cloro-a & ATP & bactéria & cloro-a & ATP \\
\hline Est.1 & 0,96 & 3,39 & 16,52 & 0,79 & 1,81 & 5,14 & 0,44 & 1,52 & 3,37 \\
Est.2 & 0,77 & 0,46 & 12,19 & 0,81 & 0,22 & 3,69 & 0,21 & 0,84 & 3,65 \\
Est.3 & 0,57 & 1,32 & 6,90 & 0,48 & 2,11 & 7,50 & 0,50 & 1,12 & 5,68 \\
Est.4 & 0,50 & 0,92 & 18,46 & 0,25 & 0,72 & 4,41 & 0,37 & 0,49 & 4,15 \\
Est.5 & 0,17 & 2,48 & 5,02 & 0,20 & 1,68 & 4,76 & 0,32 & 0,72 & 12,62 \\
Est.6 & 0,23 & 1,15 & 5,37 & 0,21 & 1,69 & 8,88 & 0,30 & 1,10 & 31,20 \\
Est.7 & 1,34 & 1,25 & 4,84 & 0,30 & 2,83 & 26,69 & 0,45 & 0,77 & 11,04 \\
Est.8 & 1,22 & 1,69 & 13,88 & 0,74 & 2,57 & 6,39 & 0,76 & 0,25 & 6,35 \\
\hline \hline
\end{tabular}


DEZEMBRO FEVEREIRO ABRIL JUNHO AGOSTO NOVEMBRO

St 1
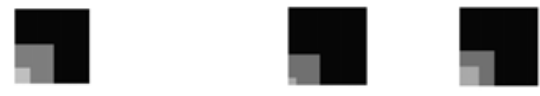

5

7
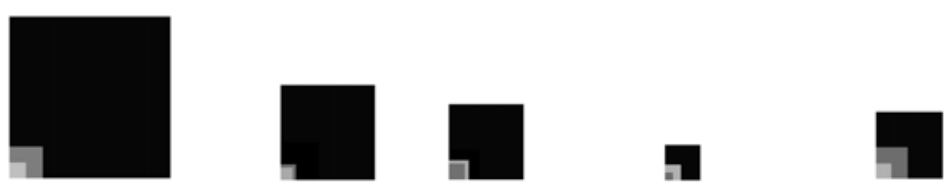

St 3
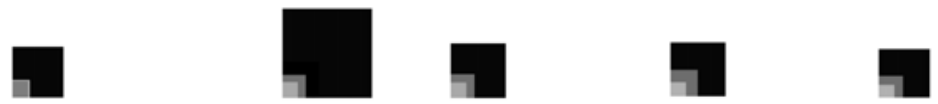

St 4
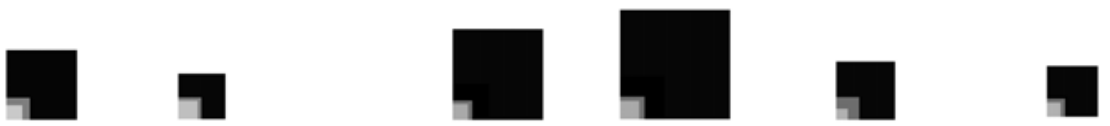

St 5
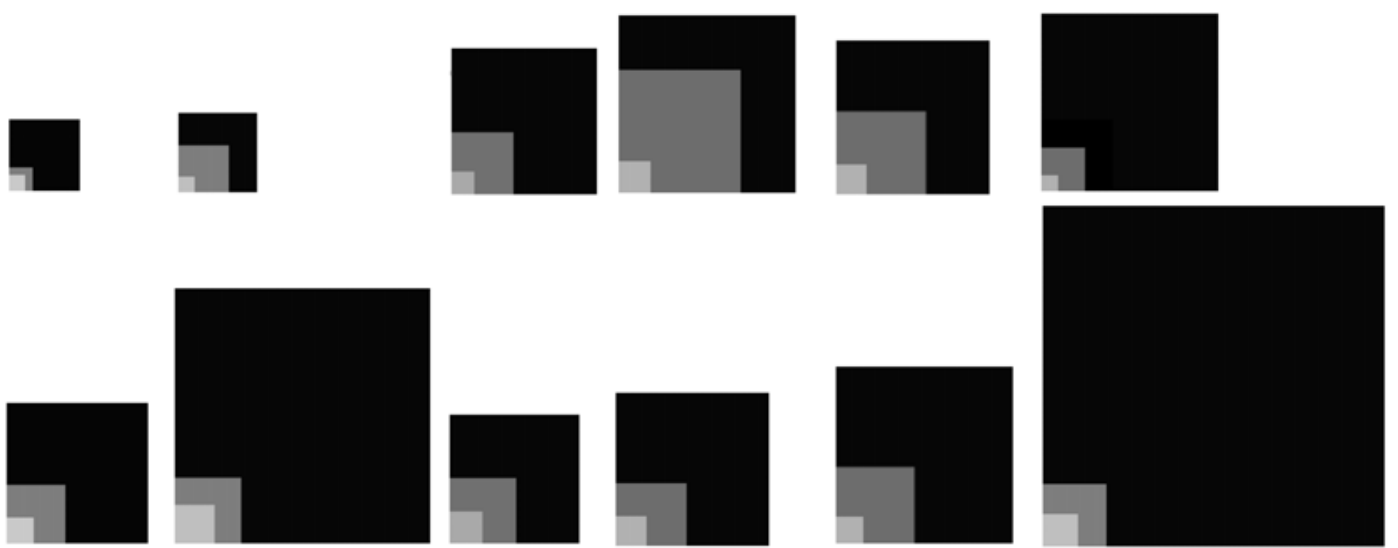

St 6
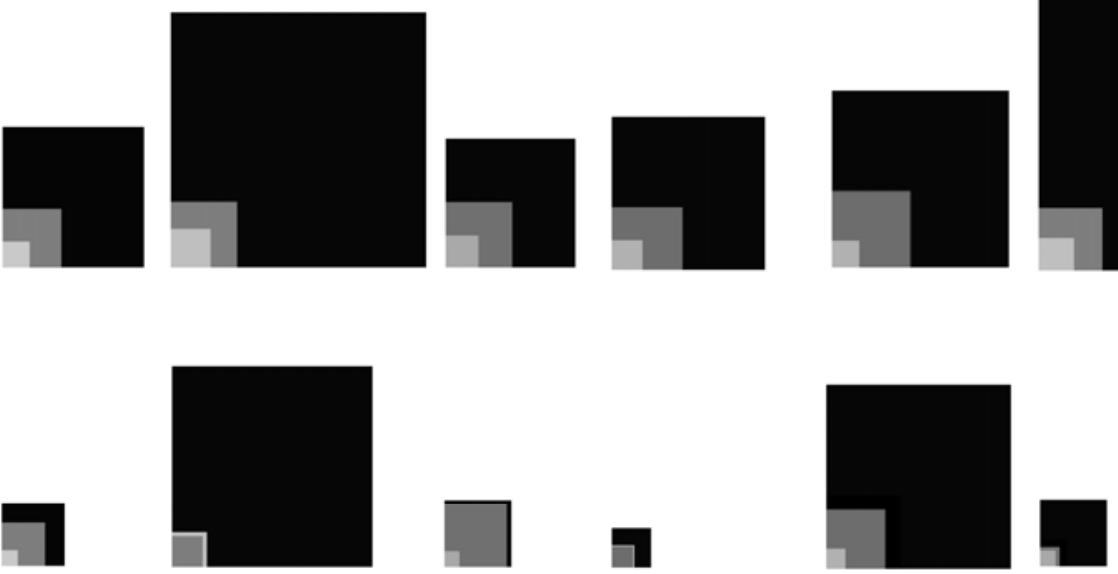

St 7
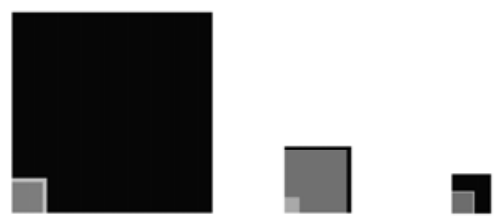

St 8
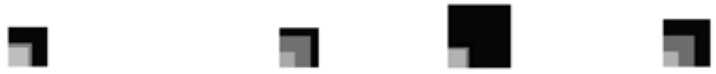

5

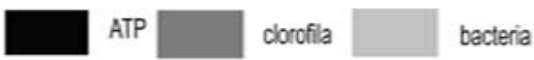

Figura 26: Esquema ilustrativo dos pools relativos às comunidades microbianas em cada estação e mês de coleta. Foram utilizados valores médios da camada superficial do sedimento (0-2 $\mathrm{cm}$ ) dos valores de biomassa baseados no ATP, em clorofila-a e biomassa bacteriana (Figuras em escala). 
A biomassa microbiana compreende a biomassa de vários organismos como bactérias, protozoários e até de pequenos animais da meiofauna. A contribuição bacteriana na biomassa microbiana total da coluna sedimentar integrada mostrou uma grande variação dependendo do mês e estação de coleta, variando de 0,6 a 54,6\% da biomassa microbiana total do sedimento. Maiores valores de contribuição bacteriana na biomassa microbiana foram observados na estação 8 na maior parte dos meses (Figura 27).
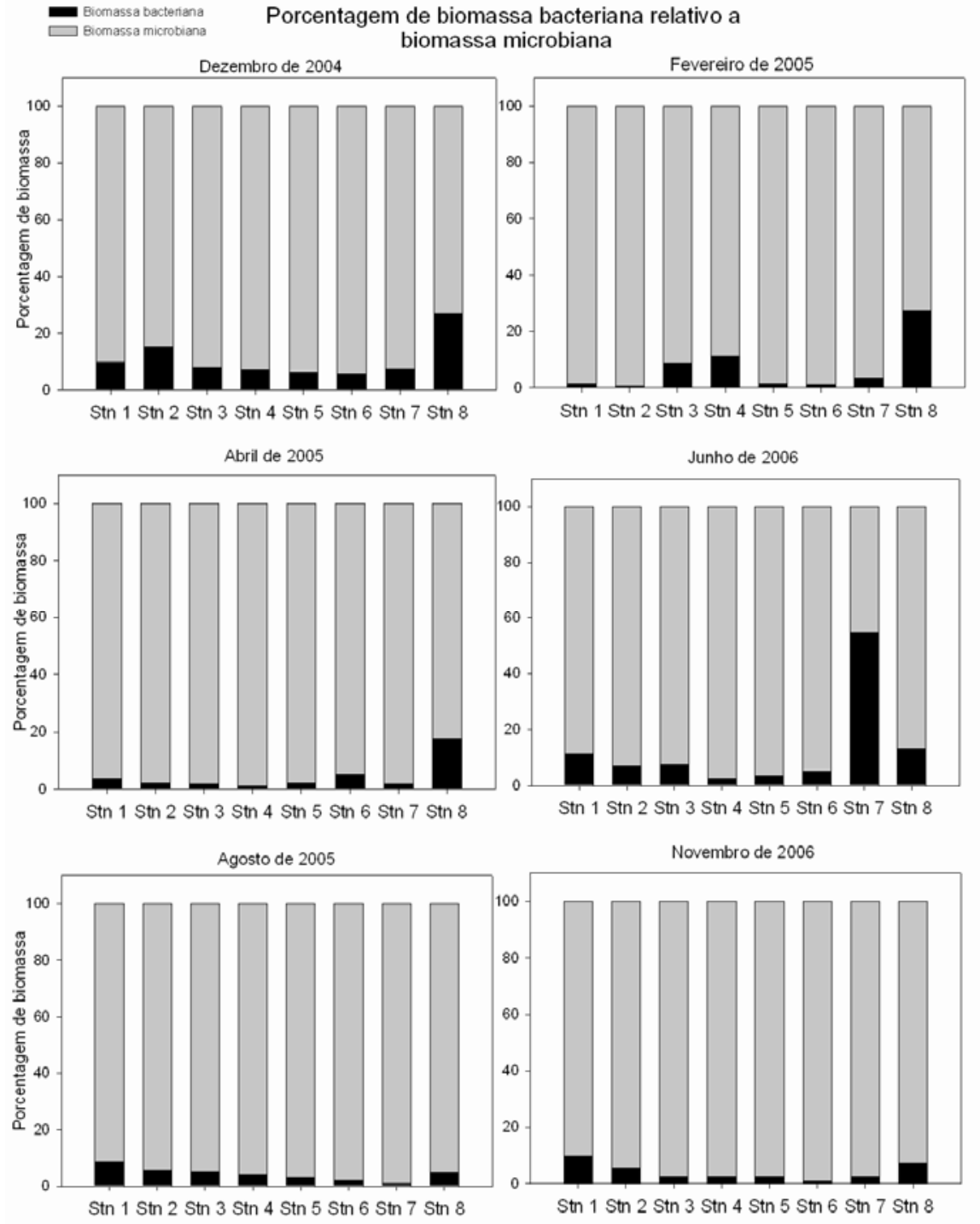

Figura 27: Porcentagem de biomassa bacteriana relativa à biomassa microbiana nas estações em cada mês de coleta (St 1 a 4 enseada de Fortaleza e St 5 a 8 enseada de Ubatuba). 


\subsection{Distribuição vertical da comunidade bacteriana}

Os maiores valores de densidade de biomassa bacteriana foram encontrados, de um modo geral, no estrato superior do sedimento $(0-2 \mathrm{~cm})$. Porém, cada enseada apresentou um padrão específico de distribuição entre os estratos, tanto para densidade (Figuras 28 e 29) quanto para biomassa (Figuras 30 e 31).

Todas as estações apresentaram diferenças significativas entre os valores de densidade e biomassa bacteriana nos estratos de coleta $(p<0,05)$ na maior parte dos meses de estudo (Tabela 14). Os maiores valores no estrato superficial do sedimento $(0-2 \mathrm{~cm})$ foram encontrados em fevereiro, exceto para a estação 8 (Tabela 14).

A porcentagem de células em divisão apresentou valores variáveis entre os estratos, não mostrando nenhuma tendência marcada na atividade bacteriana (Figuras $32 \mathrm{e}$ 33). Contudo, foi observado que em muitos casos a maior atividade bacteriana ocorreu na camada mais profunda do sedimento $(5-10 \mathrm{~cm})$, em especial na estação $3 \mathrm{em}$ abril (Figura 32). $\mathrm{Na}$ verdade, esta estação apresentou maiores valores neste estrato do sedimento na maioria dos meses estudados.

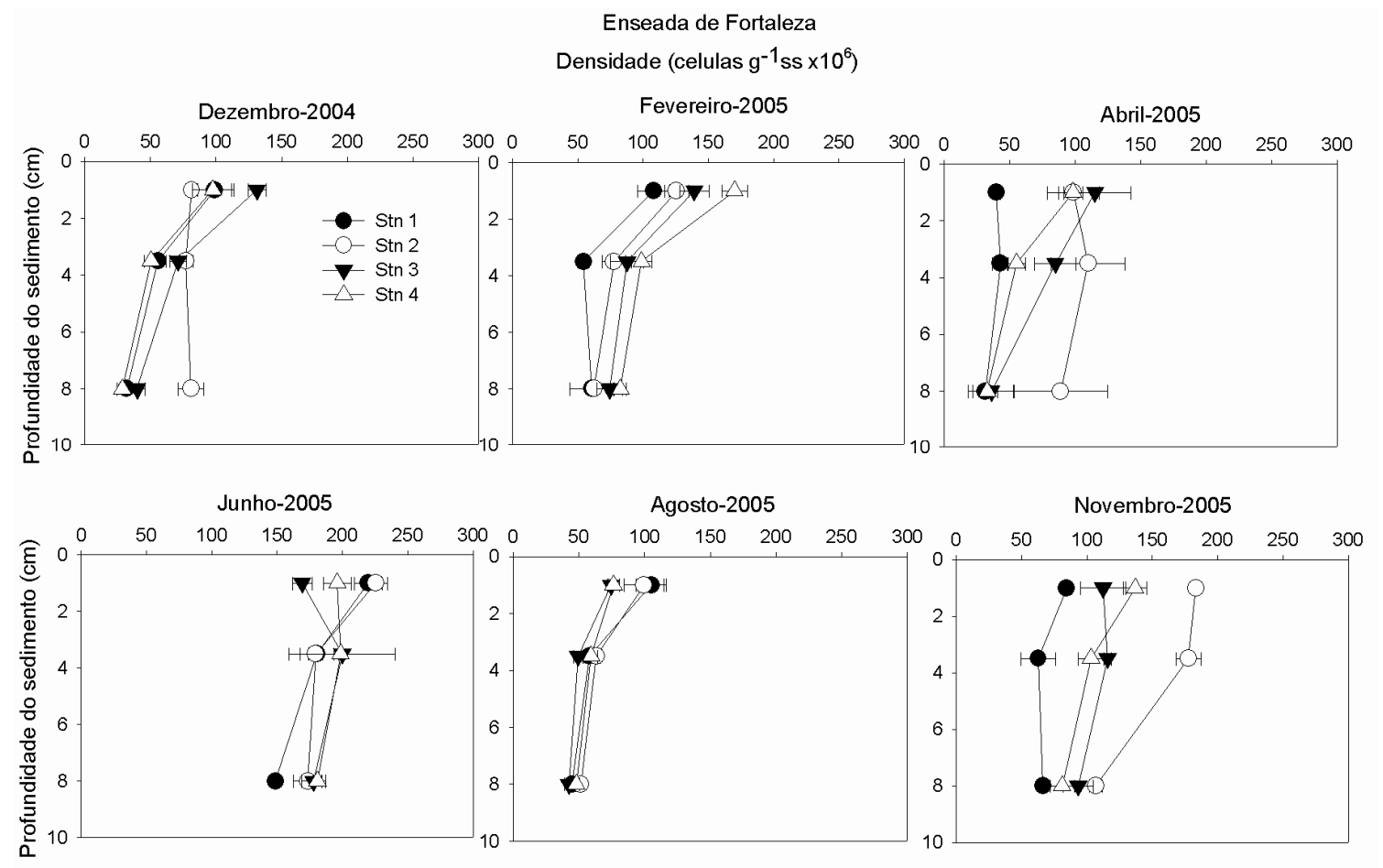

Figura 28: Perfil vertical dos valores de densidade bacteriana na Fortaleza nos meses de coleta. Barras horizontais indicam o erro padrão. 


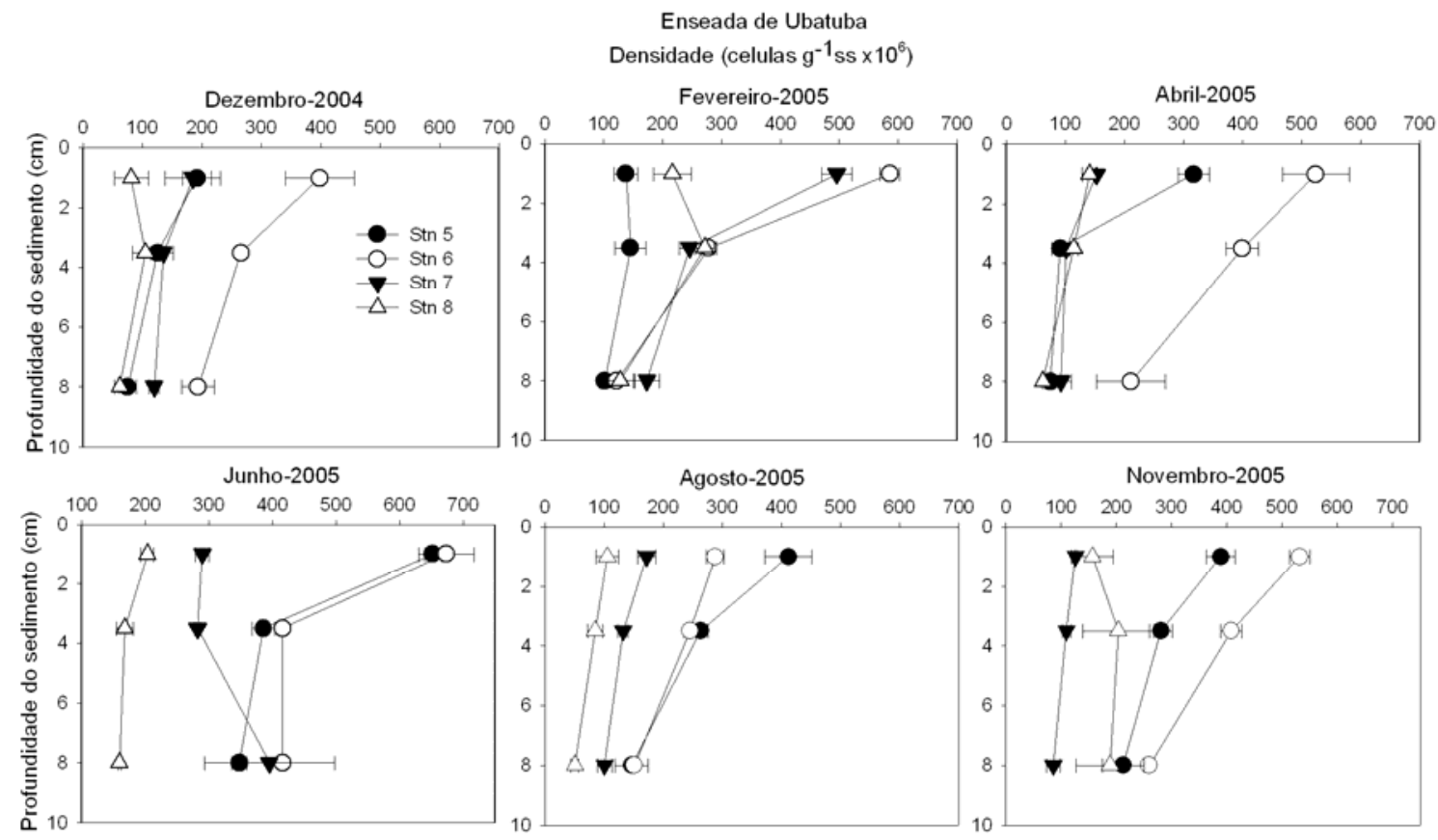

Figura 29: Perfil vertical dos valores de densidade bacteriana em Ubatuba nos meses de coleta. Barras horizontais indicam o erro padrão.

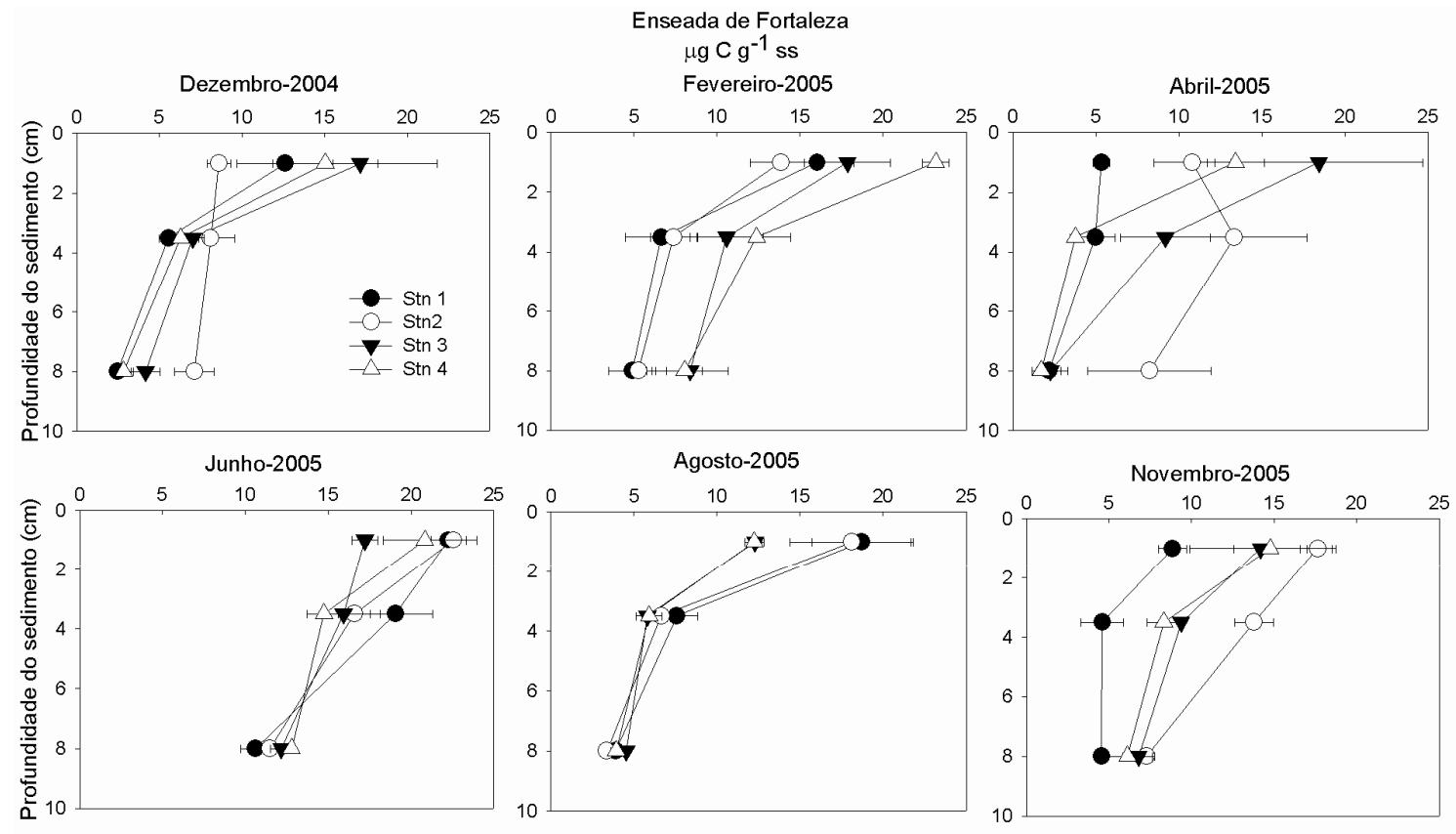

Figura 30: Perfil vertical dos valores de biomassa bacteriana na Fortaleza nos meses de coleta. Barras horizontais indicam o erro padrão. 


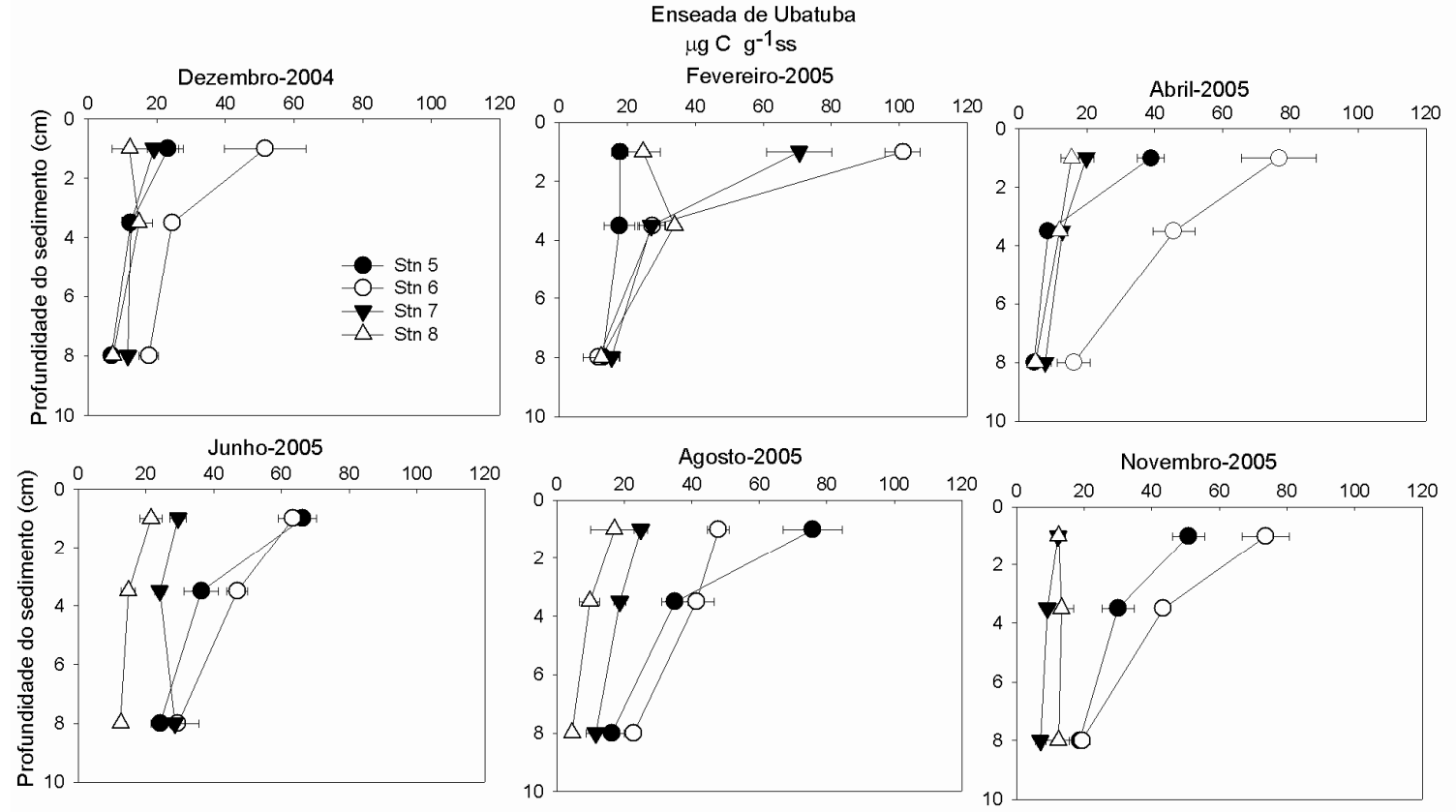

Figura 31: Perfil vertical dos valores de biomassa bacteriana em Ubatuba nos meses de coleta. Barras horizontais indicam o erro padrão.

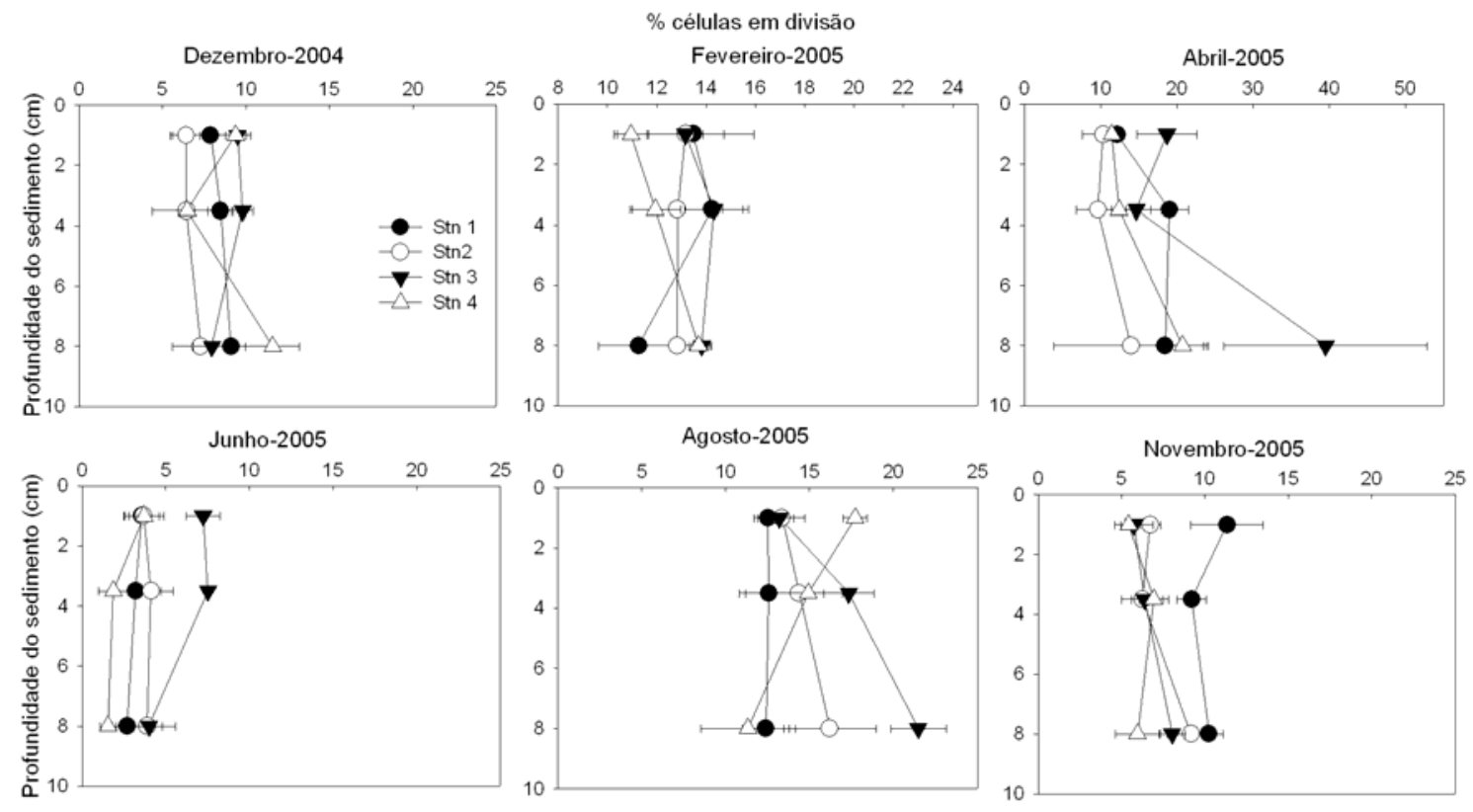

Figura 32: Perfil vertical das porcentagens médias de células em divisão na enseada de Fortaleza nos meses estudados. Barras horizontais indicam o erro padrão. 


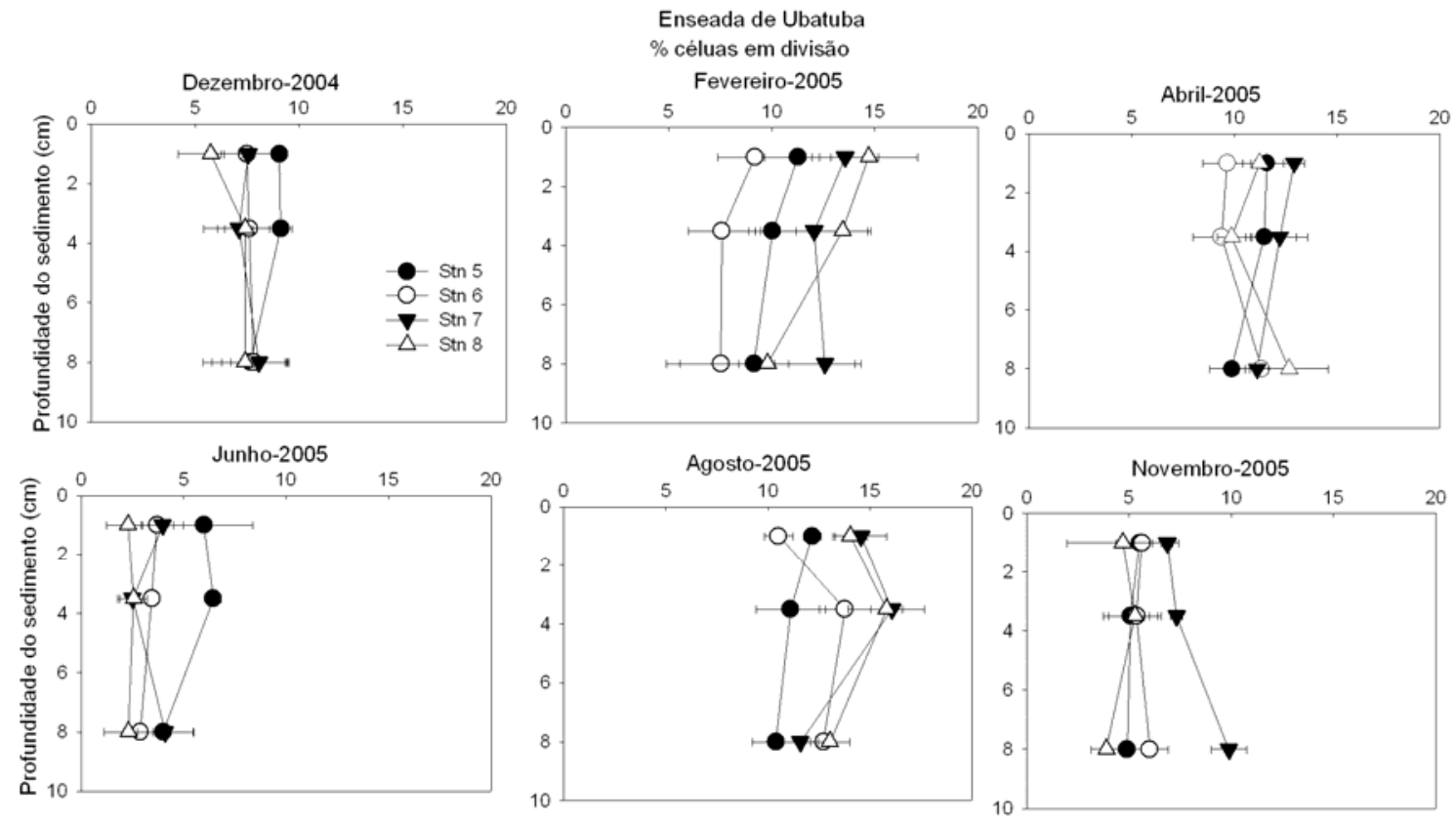

Figura 33: Perfil vertical das porcentagens médias de células em divisão na enseada de Ubatuba nos meses estudados. Barras horizontais indicam o erro padrão. 
Tabela 14: Resultados estatísticos do teste ANOVA $(\mathrm{p}<0,05)$ referentes aos valores de densidade e biomassa bacterianas nos estratos do sedimento, em cada estação e mês de coleta. ns: valores do testes não apresentaram diferenças significativas $(\mathrm{p}>0,05)$.

\begin{tabular}{|c|c|c|c|c|c|c|c|c|c|c|c|c|c|}
\hline & parâmetro & $\mathbf{F}$ & p(cal.) & \multicolumn{3}{|c|}{ Teste "tukey" } & & parâmetro & $\mathbf{F}$ & p(cal.) & \multicolumn{3}{|c|}{ Teste "tukey" } \\
\hline \multirow{3}{*}{ Dezembro } & \multirow{3}{*}{$\begin{array}{c}\text { densidade } \\
\text { biomassa }\end{array}$} & \multirow{3}{*}{$\begin{array}{l}16,846 \\
16,062\end{array}$} & \multirow{3}{*}{$\begin{array}{l}0,004 \\
0,004\end{array}$} & $5-10 \mathrm{~cm}$ & $2-5 \mathrm{~cm}$ & \multirow{2}{*}{$0-2 \mathrm{~cm}$} & \multirow{3}{*}{$\begin{array}{l}\text { Estação } 5 \\
\text { Dezembro }\end{array}$} & \multirow{2}{*}{ densidade } & \multirow{2}{*}{11,047} & \multirow{3}{*}{0,010} & \multirow{3}{*}{$5-10 \mathrm{~cm}$} & $2-5 \mathrm{~cm}$ & \multirow{2}{*}{$0-2 \mathrm{~cm}$} \\
\hline & & & & & & & & & & & & & \\
\hline & & & & & & & & biomassa & ns & & & & \\
\hline \multirow[t]{4}{*}{ Fevereiro } & \multirow[t]{2}{*}{ densidade } & \multirow[t]{2}{*}{5,866} & \multirow[t]{2}{*}{0,038} & $2-5 \mathrm{~cm}$ & $5-10 \mathrm{~cm}$ & \multirow[t]{2}{*}{$0-2 \mathrm{~cm}$} & \multirow[t]{2}{*}{ Fevereiro } & \multirow{2}{*}{$\begin{array}{c}\text { densidade } \\
\text { biomassa }\end{array}$} & \multirow{2}{*}{$\begin{array}{l}\mathrm{ns} \\
\mathrm{ns}\end{array}$} & & & & \\
\hline & & & & & & & & & & & & & \\
\hline & \multirow{2}{*}{ biomassa } & \multirow{2}{*}{9,213} & \multirow{2}{*}{0,015} & $3-100111$ & $2-5 \mathrm{~cm}$ & \multirow{2}{*}{$0-2 \mathrm{~cm}$} & Abril & densidade & 62329 & 0.000 & $5-10 \mathrm{~cm}$ & $2-5 \mathrm{~cm}$ & $0-2 \mathrm{~cm}$ \\
\hline & & & & & & & & biomassa & 68,161 & 0,000 & & & \\
\hline \multirow[t]{2}{*}{ Abril } & \multirow{3}{*}{$\begin{array}{c}\text { densidade } \\
\text { biomassa }\end{array}$} & \multirow{3}{*}{$\begin{array}{l}\mathrm{ns} \\
\mathrm{ns}\end{array}$} & & & & & & & & & & & \\
\hline & & & & & & & \multirow[t]{2}{*}{ Junho } & \multirow{2}{*}{$\begin{array}{c}\text { densidade } \\
\text { biomassa }\end{array}$} & 129,858 & 0,000 & $5-10 \mathrm{~cm}$ & $2-5 \mathrm{~cm}$ & $0-2 \mathrm{~cm}$ \\
\hline Junho & & & 0007 & $5-10 \mathrm{~cm}$ & $2-5 \mathrm{~cm}$ & $0-2 \mathrm{~cm}$ & & & & 0,001 & & & \\
\hline & & & & & & & Agosto & densidade & 20,963 & 0,002 & $5-10 \mathrm{~cm}$ & $2-5 \mathrm{~cm}$ & $0-2 \mathrm{~cm}$ \\
\hline & biomassa & 18,200 & 0,003 & $5-10 \mathrm{~cm}$ & $2-5 \mathrm{~cm}$ & $0-2 \mathrm{~cm}$ & & biomassa & 26,662 & 0,001 & & & \\
\hline & & & & & & & Novembro & densidade & 9,338 & 0,014 & $5-10 \mathrm{~cm}$ & $2-5 \mathrm{~cm}$ & $0-2 \mathrm{~cm}$ \\
\hline Agosto & densidade & 18,324 & 0,003 & $5-10 \mathrm{~cm}$ & $2-5 \mathrm{~cm}$ & $0-2 \mathrm{~cm}$ & & & & & & & \\
\hline & biomassa & 16,220 & 0,004 & & & & & biomassa & 14,497 & 0,005 & $5-10 \mathrm{~cm}$ & $2-5 \mathrm{~cm}$ & $0-2 \mathrm{~cm}$ \\
\hline Novembro & densidade & ns & & & & & & & & & & & \\
\hline & biomassa & 7,093 & 0,026 & $5-10 \mathrm{~cm}$ & $2-5 \mathrm{~cm}$ & $0-2 \mathrm{~cm}$ & Estação 6 & & & & & & \\
\hline & & & & & & & Dezembro & densidade & 9,038 & 0,016 & $5-10 \mathrm{~cm}$ & $2-5 \mathrm{~cm}$ & $0-2 \mathrm{~cm}$ \\
\hline Estação 2 & & & & & & & & Diomassa & & & & & \\
\hline Dezembro & densidade & ns & & & & & Fevereiro & densidade & 349,113 & $<0,0001$ & $5-10 \mathrm{~cm}$ & $2-5 \mathrm{~cm}$ & $0-2 \mathrm{~cm}$ \\
\hline & biomassa & ns & & & & & & & & & & & \\
\hline Fevereiro & densidade & 20,750 & 0,002 & $5-10 \mathrm{~cm}$ & $2-5 \mathrm{~cm}$ & $0-2 \mathrm{~cm}$ & & biomassa & 161,029 & 0,000 & $5-10 \mathrm{~cm}$ & $2-5 \mathrm{~cm}$ & $0-2 \mathrm{~cm}$ \\
\hline & biomassa & 10,873 & 0,010 & & & & & & & & & & \\
\hline
\end{tabular}




\begin{tabular}{|c|c|c|c|c|c|c|c|c|c|c|c|c|c|}
\hline \multirow[t]{3}{*}{ Abril } & densidade & ns & & & & & \multirow[t]{4}{*}{ Abril } & \multirow{4}{*}{$\begin{array}{c}\text { densidade } \\
\text { biomassa }\end{array}$} & \multirow{4}{*}{$\begin{array}{l}10,111 \\
14,974\end{array}$} & \multirow{4}{*}{$\begin{array}{l}0,012 \\
0,005\end{array}$} & \multirow{4}{*}{$\begin{array}{l}5-10 \mathrm{~cm} \\
5-10 \mathrm{~cm} \\
\end{array}$} & \multirow[t]{2}{*}{$2-5 \mathrm{~cm}$} & \multirow[t]{2}{*}{$0-2 \mathrm{~cm}$} \\
\hline & biomassa & ns & & & & & & & & & & & \\
\hline & & & & & & & & & & & & $2-5 \mathrm{~cm}$ & $0-2 \mathrm{~cm}$ \\
\hline \multirow[t]{2}{*}{ Junho } & densidade & 10,158 & 0,012 & $5-10 \mathrm{~cm}$ & $2-5 \mathrm{~cm}$ & $0-2 \mathrm{~cm}$ & & & & & & & \\
\hline & biomassa & 26,404 & 0,001 & $5-10 \mathrm{~cm}$ & $2-5 \mathrm{~cm}$ & $0-2 \mathrm{~cm}$ & Junho & $\begin{array}{c}\text { densidade } \\
\text { biomassa }\end{array}$ & $\begin{array}{l}21,134 \\
29,249\end{array}$ & $\begin{array}{l}0,002 \\
0,001\end{array}$ & $5-10 \mathrm{~cm}$ & $2-5 \mathrm{~cm}$ & $0-2 \mathrm{~cm}$ \\
\hline \multirow[t]{3}{*}{ Agosto } & densidade & 208,782 & $<0,0001$ & $5-10 \mathrm{~cm}$ & $2-5 \mathrm{~cm}$ & $0-2 \mathrm{~cm}$ & \multirow[t]{2}{*}{ Agosto } & \multirow{2}{*}{$\begin{array}{c}\text { densidade } \\
\text { biomassa }\end{array}$} & \multirow{2}{*}{$\begin{array}{l}40,787 \\
12,259\end{array}$} & \multirow{2}{*}{$\begin{array}{l}0,000 \\
0,008\end{array}$} & $5-10 \mathrm{~cm}$ & $2-5 \mathrm{~cm}$ & $0-2 \mathrm{~cm}$ \\
\hline & \multirow{2}{*}{ biomassa } & \multirow{2}{*}{20,385} & \multirow{2}{*}{0,002} & $5-10 \mathrm{~cm}$ & $2-5 \mathrm{~cm}$ & \multirow{2}{*}{$0-2 \mathrm{~cm}$} & & & & & & & \\
\hline & & & & & & & Novembro & densidade & 78,940 & 0,000 & $5-10 \mathrm{~cm}$ & $2-5 \mathrm{~cm}$ & $0-2 \mathrm{~cm}$ \\
\hline \multirow[t]{2}{*}{ Novembro } & \multirow{2}{*}{$\begin{array}{c}\text { densidade } \\
\text { biomassa }\end{array}$} & \multirow{2}{*}{$\begin{array}{l}43,808 \\
30,095\end{array}$} & \multirow{2}{*}{$\begin{array}{l}0,000 \\
0,001\end{array}$} & $5-10 \mathrm{~cm}$ & $2-5 \mathrm{~cm}$ & \multirow[t]{2}{*}{$0-2 \mathrm{~cm}$} & & & & & & & \\
\hline & & & & & & & & biomassa & 7,2 & 0,027 & $5-10 \mathrm{~cm}$ & $2-5 \mathrm{~cm}$ & $0-2 \mathrm{~cm}$ \\
\hline \multicolumn{14}{|l|}{ Estaçãa 3} \\
\hline \multirow[t]{4}{*}{ Dezembro } & \multirow[t]{2}{*}{ densidade } & \multirow[t]{2}{*}{52,289} & \multirow[t]{2}{*}{0,000} & \multirow[t]{2}{*}{$5-10 \mathrm{~cm}$} & $2-5 \mathrm{~cm}$ & \multirow[t]{2}{*}{$0-2 \mathrm{~cm}$} & $\begin{array}{l}\text { Estação } 7 \\
\text { Dezembro }\end{array}$ & ade & ns & & & & \\
\hline & & & & & & & & biomassa & ns & & & & \\
\hline & biomassa & 9,210 & 0,015 & $5-10 \mathrm{~cm}$ & $2-5 \mathrm{~cm}$ & $0-2 \mathrm{~cm}$ & & & & & & & \\
\hline & & & & & & & Fevereiro & densidade & 59,097 & 0,000 & $5-10 \mathrm{~cm}$ & $2-5 \mathrm{~cm}$ & $0-2 \mathrm{~cm}$ \\
\hline Fevereiro & densidade & 9,391 & 0,014 & $5-10 \mathrm{~cm}$ & $2-5 \mathrm{~cm}$ & $0-2 \mathrm{~cm}$ & & biomassa & 22,567 & 0,002 & & & \\
\hline & & & & & & & Abril & densidade & ns & & & & \\
\hline & biomassa & ns & & & & & & biomassa & 10,009 & 0,012 & $5-10 \mathrm{~cm}$ & $2-5 \mathrm{~cm}$ & $0-2 \mathrm{~cm}$ \\
\hline Abril & densidade & ns & & & & & & & & & & & \\
\hline & biomassa & ns & & & & & Junho & densidade & ns & & & & \\
\hline Junho & densidade & ns & & & & & & biomassa & ns & & & & \\
\hline & biomassa & ns & & & & & Agosto & densidade & 8,201 & 0,019 & $5-10 \mathrm{~cm}$ & $2-5 \mathrm{~cm}$ & $0-2 \mathrm{~cm}$ \\
\hline & & & & & & & & biomassa & 8,941 & 0,016 & & & \\
\hline
\end{tabular}




\begin{tabular}{|c|c|c|c|c|c|c|c|c|c|c|c|c|c|}
\hline \multirow[t]{2}{*}{ Agosto } & \multirow{2}{*}{$\begin{array}{c}\text { densidade } \\
\text { biomassa }\end{array}$} & \multirow{2}{*}{$\begin{array}{c}31,675 \\
168\end{array}$} & \multirow{2}{*}{$\begin{array}{c}0,001 \\
<0,0001\end{array}$} & $5-10 \mathrm{~cm}$ & $2-5 \mathrm{~cm}$ & $0-2 \mathrm{~cm}$ & \multirow{3}{*}{ Novembro } & \multirow{3}{*}{$\begin{array}{c}\text { densidade } \\
\text { biomassa }\end{array}$} & \multirow{3}{*}{$\begin{array}{l}5,375 \\
6,127\end{array}$} & \multirow{3}{*}{$\begin{array}{l}0,046 \\
0,046\end{array}$} & \multirow{3}{*}{$5-10 \mathrm{~cm}$} & \multirow{3}{*}{$2-5 \mathrm{~cm}$} & \multirow[b]{2}{*}{$0-2 \mathrm{~cm}$} \\
\hline & & & & & & & & & & & & & \\
\hline \multirow{2}{*}{ Novembro } & densidade & $\mathrm{ns}$ & & & & & & & & & & & \\
\hline & biomassa & $\mathrm{ns}$ & & & & & \multirow{3}{*}{$\begin{array}{l}\text { Estação } 8 \\
\text { Dezembro }\end{array}$} & & & & & & \\
\hline \multirow[t]{3}{*}{$\begin{array}{l}\text { Estação } 4 \\
\text { Dezembro }\end{array}$} & \multirow{3}{*}{$\begin{array}{c}\text { densidade } \\
\text { biomassa }\end{array}$} & \multirow{3}{*}{$\begin{array}{c}13,293 \\
10,10\end{array}$} & \multirow{3}{*}{$\begin{array}{l}0,007 \\
0,012\end{array}$} & $5-10 \mathrm{~cm}$ & $2-5 \mathrm{~cm}$ & \multirow{2}{*}{$0-2 \mathrm{~cm}$} & & $\begin{array}{c}\text { densidade } \\
\text { biomassa }\end{array}$ & $\begin{array}{l}\mathrm{ns} \\
\mathrm{ns}\end{array}$ & & & & \\
\hline & & & & & & & & & & & & & \\
\hline & & & & & & & \multirow[t]{3}{*}{ Fevereiro } & \multirow{3}{*}{$\begin{array}{c}\text { densidade } \\
\text { biomassa }\end{array}$} & \multirow{3}{*}{$\begin{array}{l}8,4941 \\
6,3979\end{array}$} & \multirow{3}{*}{$\begin{array}{l}0,0182 \\
0,0327\end{array}$} & $5-10 \mathrm{~cm}$ & $0-2 \mathrm{~cm}$ & \multirow[t]{3}{*}{$2-5 \mathrm{~cm}$} \\
\hline \multirow[t]{3}{*}{ Fevereiro } & \multirow{3}{*}{$\begin{array}{c}\text { densidade } \\
\text { biomassa }\end{array}$} & \multirow{3}{*}{$\begin{array}{l}35,951 \\
30,168\end{array}$} & \multirow{3}{*}{$\begin{array}{l}0,000 \\
0,001\end{array}$} & $5-10 \mathrm{~cm}$ & $2-5 \mathrm{~cm}$ & \multirow[t]{2}{*}{$0-2 \mathrm{~cm}$} & & & & & & & \\
\hline & & & & & & & & & & & & & \\
\hline & & & & & & & \multirow[t]{4}{*}{ Abril } & densidade & 23,318 & 0,002 & $5-10 \mathrm{~cm}$ & $2-5 \mathrm{~cm}$ & $0-2 \mathrm{~cm}$ \\
\hline \multirow[t]{2}{*}{ Abril } & \multirow{2}{*}{$\begin{array}{c}\text { densidade } \\
\text { biomassa }\end{array}$} & 32,809 & 0,001 & $5-10 \mathrm{~cm}$ & $2-5 \mathrm{~cm}$ & \multirow[t]{2}{*}{$0-2 \mathrm{~cm}$} & & & & & & & \\
\hline & & 64,334 & 0,000 & & & & & biomassa & 6,594 & 0,030 & $5-10 \mathrm{~cm}$ & $2-5 \mathrm{~cm}$ & $0-2 \mathrm{~cm}$ \\
\hline Junho & densidade & ns & & & & & & & & & & & \\
\hline & biomassa & 8,420 & 0,018 & $5-10 \mathrm{~cm}$ & $2-5 \mathrm{~cm}$ & $0-2 \mathrm{~cm}$ & Junho & densidade & 5,948 & 0,037 & $5-10 \mathrm{~cm}$ & $2-5 \mathrm{~cm}$ & $0-2 \mathrm{~cm}$ \\
\hline & & & & & & & & biomassa & ns & & & & \\
\hline Agosto & densidade & 11,07 & 0,010 & $5-10 \mathrm{~cm}$ & $2-5 \mathrm{~cm}$ & $0-2 \mathrm{~cm}$ & & & & & & & \\
\hline & & & & & & & Agosto & densidade & ns & & & & \\
\hline & biomassa & 53,891 & 0,000 & $5-10 \mathrm{~cm}$ & $2-5 \mathrm{~cm}$ & $0-2 \mathrm{~cm}$ & & biomassa & $\mathrm{ns}$ & & & & \\
\hline & & & & & & & Novembro & densidade & ns & & & & \\
\hline Novembro & densidade & 8,979 & 0,016 & $5-10 \mathrm{~cm}$ & $2-5 \mathrm{~cm}$ & $0-2 \mathrm{~cm}$ & & biomassa & ns & & & & \\
\hline & biomassa & 7,434 & 0,024 & & & & & & & & & & \\
\hline
\end{tabular}




\section{Discussão}

\subsection{Variação espacial da comunidade bacteriana}

Regiões costeiras são caracterizadas por altos valores de densidade e biomassa bacteriana. A densidade e biomassa bacteriana encontradas nos sedimentos das enseadas de Ubatuba (ca. 2,53 x 109 e 1,8 x 108 cel g-1 ss e 187,3 e 27,1 $\mu \mathrm{g} \mathrm{C} \mathrm{g-1} \mathrm{ss)} \mathrm{foram} \mathrm{similares}$ aos dados encontrados na literatura para diferentes regiões costeiras (Dale, 1974; MeyerReil et al., 1978; Meyer-Reil, 1983; Danovaro \& Fabiano, 1995; Albertelli et al., 1999; Dietrich \& Arndt, 2000; Stoecck \& Krönche,2001).

A disponibilidade de matéria orgânica em áreas costeiras é caracterizada por uma grande variabilidade na composição e degradabilidade, variando de recursos lábeis, como o fitoplâncton e microalgas bênticas, a recursos refratários, tais como macrófitas e materiais terrestres provenientes do continente (Bouillon \& Boschker, 2006). A variabilidade de fontes de carbono leva a respostas variadas da comunidade bacteriana, em função da quantidade e principalmente da qualidade da matéria orgânica sedimentar.

A região costeira de Ubatuba possui uma variedade de fontes de origem marinha, contribuindo para a matéria orgânica do sedimento, que incluem fitoplâncton, fezes e carcaças do zoobentos e zooplâncton, além de autótrofos bênticos (microfitobentos). Estes são considerados compostos lábeis para a comunidade bacteriana. A quantificação de tais compostos foi feita a partir de valores de clorofila-a e razão clorofila-a/feopigmentos (cloro/feo) sedimentares, biomarcadores lipídicos e razão C/N (Projeto DIAGEN).

Em todas as épocas amostradas, os maiores valores de densidade e biomassa bacteriana foram encontrados na enseada de Ubatuba. Esta enseada apresentou altos valores de matéria orgânica total (MOT) sugerindo uma maior quantidade de alimento para a fauna bêntica do que a encontrada na enseada de Fortaleza. Estudos com comunidades bacterianas confirmam que bactérias tendem a dominar áreas costeiras caracterizadas por grandes concentrações de matéria orgânica (Schimidt et al., 1998; Albertelli et al, 1999). O menor hidrodinamismo da enseada e a característica mais eutrófica, relacionada a maiores contribuições de material de origem terrestre (devido ao aporte fluvial) e marinha (como clorofila-a e feopigmentos), promove um maior acúmulo de MOT e COT nesta enseada quando comparado à enseada de Fortaleza, mais hidrodinâmica (Mahiques et al., 1998). O 
aumento da ocupação humana na enseada de Ubatuba (onde se situa o centro da cidade de Ubatuba) também tem acarretado um aumento significativo no aporte de matéria orgânica via descarga de esgoto (Muniz et al., 2006).

A quantidade e, principalmente, a qualidade da matéria orgânica local em sedimentos superficiais são fatores-chave na estruturação e metabolismo da comunidade bêntica (Graf et al., 1983; Graf, 1989). Maiores valores de clorofila-a e biomarcadores lipídicos referentes a produtores primários encontrados na enseada de Ubatuba mostraram a presença de grande quantidade de matéria orgânica fresca nesta enseada. Os altos valores de densidade e biomassa bacteriana encontrados na enseada de Ubatuba provavelmente deveram-se, também, a este fator. Maiores valores bacterianos relacionados a altos teores de clorofila-a foram também encontrados em outros estudos na zona costeira (Meyer-Reil 1983; Dietrich \& Ardnt, 2000; Kröncke et al., 2004; Stöeck \& Kröncke).

A resposta à quantidade e qualidade da matéria orgânica pela comunidade bacteriana também foi observada na distribuição da abundância e biomassa nas estações da enseada de Ubatuba. O padrão de circulação na enseada promove um acúmulo de matéria orgânica em sua porção central (Mahiques et al., 1998). Nas estações centrais maiores valores de clorofila-a e MOT foram acompanhados por aumento nos valores de densidade e biomassa bacteriana, mostrando correlação positiva entre estes fatores. Razões cloro/feo mais elevadas também foram encontradas nestas estações, sugerindo uma maior qualidade da matéria orgânica. Os testes estatísticos mostraram altas correlações positivas entre a densidade e biomassa bacteriana e a clorofila-a na distribuição entre as estações desta enseada, mostrando a resposta bacteriana a altos valores de matéria orgânica de alta qualidade.

Na enseada de Fortaleza, não foi encontrada correlação entre os dados de biomassa e densidade bacteriana e a matéria orgânica (MOT ou clorofila-a e feopigmento) na maioria dos meses estudados. A razão cloro/feo mostrou maior qualidade da matéria orgânica na estação 1, que apresentou baixos valores bacterianos. Isto sugere que a qualidade da matéria orgânica não parece ser o principal fator influenciando a distribuição bacteriana nesta enseada. Apenas no mês de novembro (na estação 2) isto ocorreu. Porém, diferenças significativas entre a densidade e biomassa bacteriana das estações foram pouco observadas mostrando uma maior homogeneidade entre as estações da enseada de Fortaleza, o que 
também foi observado com os valores de matéria orgânica e clorofila-a medidos no sedimento.

A distribuição da comunidade bacteriana na área de estudo não está apenas ligada a fatores abióticos, como granulometria e temperatura de fundo, mas podem também ser resultado de diferenças na pressão de predação entre as estações. Outros fatores físicos, tais como temperatura e tamanho médio dos grãos, também podem afetar a comunidade bacteriana (Danovaro et al., 1994; Meyer-Reil \& Graf, 1986). A temperatura da água de fundo nas enseadas decresceu da costa para o oceano, padrão não observado com a comunidade bacteriana. Desta forma, a temperatura não parece influenciar significativamente a distribuição da densidade e biomassa encontradas em nenhuma das duas enseadas, apesar de em alguns meses ter apresentado correlação com os dados bacterianos.

A granulometria não apresentou correlação com os valores de densidade e biomassa bacterianos. Porém, é extensamente conhecido que a granulometria pode afetar diretamente a comunidade bacteriana, onde sedimentos de grãos finos acumulam um alto conteúdo de matéria orgânica e suporta uma maior biomassa microbiana quando comparado a sedimentos grossos. (Dale, 1974; Weise \& Reiheinhemeir, 1978; Mayer, 1994; Köster et al., 1997; Köster \& Meyer-Reil, 2001; Köster et al., 2005). Na enseada de Ubatuba, os maiores valores de densidade e biomassa bacteriana ocorreram nas estações apresentando maior porcentagem de frações sedimentares finas (estações 5 e 6). O padrão de circulação e orientação nordeste da boca da enseada permite o acúmulo de frações finas nas regiões centrais e internas da enseada, associados também a altos valores de carbono orgânico (Mahiques, 1995).

Já na enseada de Fortaleza, a granulometria foi mais homogênea e frações granulométricas mais finas foram encontrados na estação mais externa da enseada, fato também observado por Mahiques (1994). Este autor atribuiu esta característica ao maior hidrodinamismo da enseada, que impede a sedimentação de grãos finos e limita o acúmulo de nutrientes orgânicos e inorgânicos e promove maior transporte lateral. A distribuição da densidade e biomassa bacteriana foi mais homogênea entre as estações em Fortaleza quando comparado com Ubatuba, com exceção da estação 1, com frações granulométricas 
mais grossas, que apresentou geralmente valores menores de biomassa e densidade bacteriana.

Nenhuma correlação foi encontrada entre valores de meio- e macrofauna e a densidade e biomassa bacterianas, e a predação de bactérias por estes organismos não parece afetar significativamente a distribuição das bactérias nas enseadas. Porém, é amplamente conhecido que a pressão de predação por organismos metazoários pode influir negativamente na comunidade bacteriana (Montagna, 1984; Epstein \& Shiaris, 1992; Albertelli et al., 1999; Detrich \& Arndt, 2000). Na área de estudo, maiores valores de densidade de meiofauna foram encontrados na estação 1, o que pode ter afetado negativamente a população bacteriana local. Desta forma, os menores valores de densidade e biomassa bacteriana na estação 1, caracterizada por maiores frações de matéria orgânica lábil (alta razão cloro/feo e menores razões $\mathrm{C} / \mathrm{N}$ ) pode ter sido também devido a maior predação pela meiofauna.

A porcentagem de células em divisão, entre 2,1 e 21,3\% foi maior do que a encontrada por outros autores em ambientes de plataforma (Meyer-Reil1, 1983; Danovaro \& Fabiano, 1995; Hollnaguel, 1994; Fabiano \& Danovaro, 1998; Albertelli et al., 1999), porém foi semelhante aos valores encontrados em alguns estudos realizados em áreas de mar profundo (Danovaro, et al. 1998; Danovaro et al., 1999; Mather \& Parkes, 2000). Isso denota que a comunidade bacteriana da região caracterizou-se por altas taxas de atividade.

A atividade bacteriana nas estações de coleta não esteve relacionada a maior densidade e biomassa bacteriana, já que não foi observada diferença significativa entre as atividades apresentadas nas estações de coleta. Porém, foram observadas as maiores atividades foram encontradas na estação 3 e as menores na estação 6, que apresentou os maiores valores de densidade e biomassa. A característica mais hidrodinâmica da enseada de Fortaleza pode levar a constantes desestruturações da comunidade (como eventos de ressuspensão do sedimento), desta forma a comunidade deve se reestruturar mais constantemente e assim mantendo altas taxas de divisão celular. Este fato tem sido constantemente observado em regiões costeiras de sedimentos arenosos, onde a constante troca de solutos entre a interface sedimento-àgua e a constante desestruturação da comunidade tem sido tomada como o principal motivo para as altas taxas de atividade 
bacteriana encontrada nesses locais (Huettel \& Rusch, 2000; Rusch et al., 2000; Bühring et al., 2005).

As altas taxas de atividade bacteriana encontrada na enseada da Fortaleza também podem estar relacionadas à característica menos eutrófica da enseada. Bactérias bênticas em locais mais pobres nutricionalmente podem apresentar altas atividades para obter quantidade suficiente de compostos orgânicos para seu metabolismo (Rusch et al., 2003). E ainda, maiores atividades podem estar relacionadas a resposta de comunidades bacterianas do sedimento a eventos de sedimentação de matéria orgânica. Locais com sedimentos ricos em matéria orgânica normalmente apresentam respostas menos expressivas a tais eventos do que locais mais pobres organicamente (Törblom \& Boström, 1995). Desta forma, eventos de sedimentação de matéria orgânica ou aumento de produção microfitobêntica na enseada talvez possa levar a respostas mais intensas na atividade bacteriana. Nas estações da enseada de Ubatuba, a grande quantidade de alimento sempre disponível leva a uma estabilização da comunidade bacteriana e a uma menor taxa metabólica, levando a menores valores de atividade.

\subsection{Variação temporal.}

Vários estudos com comunidades bacterianas vêm encontrando grande sazonalidade na densidade e biomassa bacteriana em regiões de plataforma (Meyer-Reil 1983; Meyer-Reil \& Graf, 1986; Delille \& Bouvy, 1989; Graf 1989; Danovaro et al., 1994; Danovaro \& Fabiano, 1995; Danovaro, 1996; Danovaro et al., 1998; Dietrich \& Arndt, 2000) e em mar profundo (Danovaro et al., 1999, Lavigne et al., 1997; Soltwedel, 1997; Danovaro et al., 2000). No presente estudo, o padrão temporal foi marcado por maiores valores no inverno (junho), seguidos por valores de primavera-verão (novembrofevereiro). Já os menores valores de densidade e biomassa não ocorreram com um padrão espaço-temporal definido.

Como nenhum dado anterior a esse foi obtido para a comunidade bacteriana na região de Ubatuba (SP), é extremamente difícil identificar os fatores que afetam as variações temporais na abundância e biomassa bacterianas. Bactérias podem se multiplicar em questão de horas e responder rapidamente a condições favoráveis de disponibilidade de recursos (Pfannkuche \& Soltwedel, 1998). 
Os resultados estatísticos não mostraram correlação entre a variação sazonal de densidade e biomassa bacteriana com nenhum fator biótico ou abiótico. Os altos valores bacterianos observados em junho em todas as estações de coleta não foram acompanhados por altos valores de MOT, clorofila-a ou feopigmentos, e a temperatura de fundo também não mostrou relação com os valores de densidade e biomassa bacterianos. Apenas a estação 5 apresentou maior quantidade de clorofila-a em junho. Desta forma, os altos valores encontrados durante esta época não podem ser tomados como um aumento na disponibilidade de alimento ou como uma resposta bacteriana bêntica ao input de matéria orgânica, nem ao aumento de matéria orgânica lábil, já que os valores de razão $\mathrm{C} / \mathrm{N}$ foram altos e os de cloro/feo foram baixos nesta época do ano.

Respostas sazonais da comunidade bacteriana relacionadas à pressão de predação por metazoários têm sido demonstradas em alguns estudos (Montagna, 1984; Alongi, 1994; Danovaro, 1996, Vezzulli \& Fabiano, 2006). Porém, tem-se observado que este padrão ocorre apenas em locais com baixa quantidade de alimento disponível (Alongi, 1994) e estudos recentes não vêm encontrando impacto de predação da comunidade bacteriana por flagelados (Epstein, 1997; Hamels et al., 2000).

Canuel \& Martins (1993) observaram que as bactérias utilizam preferencialmente material lábil durante o verão e a conversão deste material em biomassa bacteriana ocorre durante períodos de outono-inverno. Tal fato pode ter ocorrido no presente estudo. Adicionalmente, formas mais refratárias de matéria orgânica (altas razões $\mathrm{C} / \mathrm{N}$ ) podem ter sido responsáveis por um lento e contínuo aumento da densidade e biomassa bacteriana (Meyer-Reil \& Graf, 1989). Desta forma, a falta de correlação sazonal entre os valores de densidade e biomassa bacteriana e material orgânico lábil poderia ser explicada por dois fatores:

1) O acúmulo de material orgânico durante os meses de alta produtividade primária leva a altas taxas de decomposição bacteriana na interface sedimento-água, porém a baixa permeabilidade do sedimento principalmente em grãos finos diminui a taxa de degradação logo após os primeiros milímetros da coluna sedimentar (Boon et al., 1999). Deste modo, ocorre degradação anóxica, o que pode manter altas taxas de atividade, mas uma lenta conversão em biomassa bacteriana (Kristensen et al., 1995). A redução de sulfato, por exemplo, pode ser responsável por quase $100 \%$ da degradação em sedimentos 
ricos em materiais orgânicos, como sedimentos anóxicos (baixa porcentagem de degradação) (Kristensen, 2000). Desta forma, durante períodos como fevereiro e começo de abril ocorreu uma alta atividade bacteriana, porém baixa conversão em biomassa bacteriana. Esta contínua divisão celular provavelmente levou a um lento e contínuo acúmulo de densidade e biomassa que foi observado em junho.

2) A ressuspensão de sedimento devido a eventos naturais e antrópicos pode causar aumentos da atividade e biomassa bacteriana (Gastecki \& Wickham, 2001). Um estudo experimental de Fiedermondol \& Pusceddu (2004) mostrou um estímulo no crescimento bacteriano após eventos de ressuspensão moderada, que não foi seguida imediatamente por aumentos na biomassa. O mesmo foi observado por Raghukumar et al. (2001) em sedimentos de mar profundo. A ressuspensão do sedimento pode aumentar os fluxos advectivos em fundos permeáveis, aumentando o influxo de oxigênio e compostos orgânicos e inorgânicos, fazendo com que haja um aumento na taxa de remineralização e na atividade e biomassa de microorganismos (Aller \& Aller, 1998, Wakehan \& Camuel, 2005; Rusch et al., 2003). O aumento na freqüência de frentes frias durante os meses subseqüentes ao verão (abril a junho) pode ter causado um aumento da oxigenação sedimentar e a mistura do sedimento redisponibilizando a matéria orgânica das camadas mais profundas. Com o oxigênio atingindo camadas mais profundas da coluna sedimentar, esse composto passa a ser utilizado para a decomposição da matéria orgânica ainda presente em grandes quantidades, o que possivelmente levou ao grande aumento da atividade bacteriana observada no mês de abril. Os aumentos de densidade e biomassa bacteriana observada em junho podem ter decorrido deste fato. Meyer-Reil \& Graf (1984) e Törblom \& Boström (1995) relataram este lapso temporal entre a alta atividade bacteriana e o aumento de biomassa.

Na camada superficial do sedimento $(0-2 \mathrm{~cm})$, os valores foram normalizados para carbono orgânico total (COT). Esta normalização foi feita devido a aparente relação entre COT e granulometria do sedimento (Kröncke et al., 2004). Como as estações estudadas apresentaram grande variação granulométrica e esta parece também alterar a comunidade bacteriana (Köster \& Meyer-Reil, 2001; Köster et al., 1997), a normalização foi feita no intuito de eliminar a importância relativa da granulometria nos dados obtidos, tentando avaliar a matéria orgânica como principal fator dirigindo a dinâmica da comunidade 
bacteriana bêntica na interface sedimento-água. Testes estatísticos mostraram ausência de correlação significativa entre as variáveis bacterianas e MOT, clorofila-a, feopigmentos e ATP na maioria das estações. Isto sugere que a disponibilidade de alimento não é o único fator influenciando os altos valores bacterianos, como os encontrados em junho. Apenas as estações 5 e 6 na enseada de Ubatuba passaram a apresentar maiores valores de densidade e biomassa bacteriana em fevereiro e dezembro, respectivamente, acompanhando altos valores de matéria orgânica e clorofila-a. Desta forma, nestas estações as bactérias da camada superficial parecem responder ao aumento de matéria orgânica lábil no sedimento

Valores também normalizados para COT de densidade bacteriana e ácidos graxos foram comparados no verão (fevereiro) e inverno (agosto). As estações mostraram variações temporais diferenciadas, porém na maior parte dos casos os maiores valores de densidade e biomassa bacteriana acompanharam o aumento nos valores de AGP (referentes à produção primária), mostrando a influência da qualidade da matéria orgânica na variação da comunidade bêntica. Contudo, como visto anteriormente, estes dados não podem ser extrapolados para todos os meses de estudo e, portanto, resultados mais conclusivos só poderão ser obtidos quando a análise de biomarcadores lipídicos for completada para todos os meses de coleta (dados que estão sendo processados dentro do projeto DIAGEN).

Geralmente, maiores valores de células em divisão parecem acompanhar aumentos da densidade e biomassa bacteriana local (Fabiano \& Danovaro, 1994; van Duly \& Kop, 1994; Albertelli et al., 1999). No entanto, neste estudo foi observado maiores valores de porcentagem de células em divisão nos meses de abril e agosto, com menores valores sempre no mês de junho. Assim, no presente estudo altos valores de atividade bacteriana não estiveram relacionados com altos valores de densidade e biomassa nas áreas estudadas.

$\mathrm{O}$ aumento da atividade bacteriana com o aumento da temperatura tem sido amplamente encontrado em várias regiões (De Flaun \& Mayer, 1983; Alongi, 1994; Danovaro et al., 1994; Danovaro \& Fabiano, 1995; Törblom \& Boström,1995; Mather \& Parkes, 2000), assim como a resposta ao aumento matéria orgânica lábil no sedimento (Meyer-Reil, 1993; Boon et al., 1999; Halmels et al., 2001). Os maiores valores encontrados em abril podem estar relacionados com altas temperaturas de fundo nesta época do ano, adicionalmente ao já discutido aumento da mistura sedimentar devido à entrada de frentes frias. No mês de agosto, a maior parte das estações apresentou elevados 
valores de clorofila-a, indicando uma provável resposta ao aumento de matéria orgânica lábil no sedimento.

\subsection{Principais influências na variação da comunidade bacteriana.}

Os resultados da ACP mostraram uma marcada variação espacial entre as estações de coleta, porém a variação temporal observada não foi marcante. A granulometria parece ter sido uns dos principais fatores afetando a comunidade bacteriana bêntica da região, com a separação de dois grupos bem distintos, um formado pelas estações 1 e 8 com altas frações de areia e outro pelas estações 5 e 6 com altos valores de sedimentos finos (argila e silte).

A natureza do substrato afeta significativamente o regime de nutrientes sedimentares e a colonização microbiana bêntica (Dale, 1974, DeFlaun \& Mayer, 1983). Geralmente, ambientes arenosos costeiros são organicamente pobres, contendo baixos valores de carbono orgânico particulado e concentração de nutrientes, sendo também caracterizado normalmente por baixos valores densidade e biomassa bacteriana, característica observada nas estações 1 e 8 . Sedimentos lamosos, como os encontrados nas estações 5 e 6, entretanto, apresentam altas concentrações de matéria orgânica particulada, altas concentrações de nutrientes e elevado fluxo de na interface sedimento-água, levando a grandes acúmulos de densidade e biomassa bacteriana principalmente na camada superficial do sedimento (Köster \& Meyer-Reil, 2001; Köster et al., 2005).

$\mathrm{Na}$ enseada de Fortaleza, a variação dos dados também foi maior espacialmente, com pouca variação temporal. A estação 1 mais uma vez separou-se se caracterizando por altas porcentagens de areia, e baixos valores de densidade e biomassa bacteriana, mostrando a importância da granulometria afetando a variação da comunidade bêntica nesta estação. Maiores acúmulos de matéria orgânica e feopigmento foram associados com sedimentos mais finos (estação 4 e meses de dezembro e novembro nas estações 2 e 3). Esta grande porção de feopigmentos na matéria orgânica sedimentar sugere uma natureza mais refratária para a matéria orgânica nestas estações (que também apresentaram altas razões $\mathrm{C} / \mathrm{N}$ e baixas cloro/feo), quando comparados com a estação 1 (baixa razão $\mathrm{C} / \mathrm{N}$ e alta cloro/feo). Altos valores de densidade e biomassa bacteriana encontrada nestas estações, mostrando que a quantidade de matéria orgânica, mais do que a qualidade influenciou a 
comunidade bacteriana. Maiores valores de densidade e biomassa bacteriana parecem associar-se com material orgânico mais refratário quando este se encontra em grandes quantidades no ambiente (Fabiano \& Danovaro, 1994; Kröncke et al., 2004).

Um aspecto que pôde ser observado foi variação dos resultados de biomassa bacteriana entre as estações da enseada de Fortaleza. Este resultado confirma as poucas diferenças significativas encontradas entre as estações de coleta quanto à variação da densidade e biomassa bacteriana, mostrando que a enseada de Fortaleza apresentou uma distribuição mais homogênea da comunidade bacteriana nos sedimentos da enseada. Uma maior homogeneidade granulométrica e uma menor na variação da qualidade da matéria orgânica (valores de clorofila-a) na área parece ter levado a uma distribuição mais homogênea de bactérias nesta enseada.

$\mathrm{Na}$ enseada de Ubatuba, dois grupos se formaram na ACP principalmente por influência das frações granulométricas das estações. Desta forma, a enseada de Ubatuba parece ser influenciada principalmente pela sua granulometria variável, que levam a um gradiente areia-lama e ao acúmulo de matéria orgânica e clorofila-a, acompanhados por aumentos na densidade e biomassa da comunidade bacteriana da enseada (ver também Köster \& Meyer-Reil, 2001). Este padrão deveu-se principalmente ao menor hidrodinamismo da enseada e ao padrão de circulação no sentido horário, com acúmulos de materiais nas regiões centrais internas da mesma (Mahiques, 1995). Novamente, a variação sazonal não foi expressiva nesta enseada, com exceção da estação 7 .

\subsection{Normalizações.}

A abundância bacteriana tem sido freqüentemente dimensionada para o peso ou volume de sedimento seco, sendo que a maioria das publicações não inclui informações suficientes para a conversão entre dimensões. Em um número limitado de estudos, a abundância bacteriana tendeu a variar menos quando normalizada para a área de superfície dos grãos do que para o peso seco do sedimento (Dale, 1974). E ainda mais importante, escalas inapropriadas usadas para estudos em certas áreas possuindo condições físicas muito variáveis podem mascarar ou falsear a quantificação da comunidade bacteriana (Schmidt et al., 1998). Devido à marcada diferença dos parâmetros físicos entre as duas enseadas, principalmente quanto à granulometria, os dados referentes à densidade e 
biomassa bacteriana foram normalizados quanto a diferentes escalas (e.g. gramas de sedimento seco, conteúdo de água do sedimento e porosidade do sedimento), com o intuito de demonstrar a variação da comunidade bacteriana devido a escala utilizada. Schimidt et al. (1998) utilizaram diferentes normalizações em amostras referentes a vários ambientes na zona costeira e oceânica (sedimento seco e conteúdo de água). Os autores observaram diferenças significativas entre as normalizações, com uma variação significativamente menor dos dados quando estes foram escalonados para conteúdo de água.

A distribuição entre os valores de densidade e biomassa entre as estações de coleta, normalizados para sedimento seco e porosidade, foram praticamente iguais. Porém, os valores normalizados para o conteúdo de água mostraram uma distribuição diferente, principalmente considerando a estação 8 , que quando normalizada apresentou valores muito maiores do que os das outras estações de coleta. Assim como encontrado por Schimidt (1998), a variação dos dados normalizados para conteúdo de água foi menor do que a encontrada para sedimento seco, levando a valores de densidade parecidos entre as duas enseadas. Porém, cabe ressaltar que vários valores obtidos na estação 8 , no entanto, foram muito discrepantes dos demais, podendo levar a erros de interpretação.

Em resumo, as normalizações mostraram que existem diferenças entre os dados dependendo da escala a ser utilizada. No entanto, o uso de dimensões de escalas para os estudos bacterianos necessita de melhor investigação. O uso de conteúdo de água presente no sedimento parece apropriado já que a matéria orgânica dissolvida utilizada por bactérias está dissolvida na água intersticial. Porém, isso é verdade apenas para sedimentos grossos, pois em sedimentos de grãos finos a maior área superficial do grão e a natureza reativa do sedimento promove a associação de partículas sedimentares e matéria orgânica particulada (também utilizada por bactérias), e as próprias bactérias parecem, no ambiente, estar altamente associadas a partículas sedimentares (Dale, 1974). Desta forma, a escala de peso do sedimento tem sido adota pela maior parte dos estudos com densidade e biomassa bacteriana, principalmente devido à dificuldade de medidas de melhores escalas, como medidas de área superficial dos grãos, principalmente em sedimentos finos, que são a maior parte do sedimento marinho (DeFlaun \& Mayer, 1983). 


\subsection{Balanço de COT nas comunidades microbianas.}

A contribuição da biomassa bacteriana para o COT foi, em média, de 0,6\%, variando de 0,05 a $2,6 \%$ do COT. Estes dados concordam com outros dados da literatura para áreas costeiras que mostraram contribuições bacterianas variando entre $0-0,7 \%$ (Meyer-Reisl et al., 1978), 1,2\% (Dale, 1974), 1,5\% (Meyer-Reil et al., 1980), 0,2-1,7 (Köster \& Meyer-Reil, 2001) e 0,9 a 1,3\% (Köster et al., 2005).

A variação da contribuição de COT pelas comunidades microbianas não mostrou um padrão de variação específico, porém ressaltou a influência da granulometria como fator-chave para diferenças na contribuição (ver também Köster \& Meyer-Reil, 2001). Altas contribuições de biomassa autotrófica foram encontradas em alguns meses nas estações 1, 7 e 8, principalmente. Estas estações foram caracterizadas por maiores quantidades de areia na sua composição. Maiores quantidades de biomassa derivadas de clorofila-a em sedimentos arenosos também foram encontradas em outros estudos de regiões costeiras (Köster \& Meyer-Reil, 2001). Porém, contribuições da biomassa bacteriana não mostraram relação com a granulometria e foram relativamente baixas na maioria das estações estudadas. Maiores contribuições bacterianas relativas foram encontradas na estação 8, indicando que bactérias tendem a dominar locais caracterizados por matéria orgânica sedimentar de alta qualidade.

No entanto, estes dados devem ser tomados com cautela, pois extrapolações de concentração de indicadores de biomassa para carbono dependem da seleção apropriada de fatores de conversão. Fatores de conversão usados na literatura podem variar várias ordens de magnitude, principalmente devido a diferenças taxonômicas e fisiológicas dos organismos nas condições ambientais (Pelegri et al., 1999). Conversões de C:ATP podem variar de 140 a 2000 e C:clorofila-a de 10 a 150 (Köster et al., 2005). Estas diferenças podem explicar variações na contribuição de $\mathrm{C}$ de cada parcela microbiana em diferentes estudos (Köster \& Meyer-Reil, 2001). No presente estudo, foram utilizados fatores de conversão mais comuns para regiões costeiras, como uma razão de C:ATP de 250 (Karl, 1980) e C:clorofila-a de 40 (Cammen, 1991).

A contribuição bacteriana na biomassa microbiana total da coluna sedimentar integrada mostrou uma grande variação, onde a biomassa bacteriana contribui com 0,62 a $54,6 \%$ da biomassa microbiana total do sedimento. Os resultados de porcentagem de 
biomassa bacteriana foram menores do que os encontrados na literatura (Meyer-Reil, 1983; Fabiano \& Danovaro, 1998), porém os dados de biomassa bacteriana encontrados no presente estudo e nos trabalhos acima citados foram semelhantes (na ordem de $10^{-5}$ ), mostrando que na área estudada foram encontrados valores muito altos de biomassa microbiana (baseados em medida de ATP). Os resultados de ATP medem a biomassa microbiana sem distinguir entre as classes de microorganismos (inclui bactéria, protozoários e pequenos animais de meiofauna) (Karl \& Novitsky, 1988). Desta forma, a região estudada parece ser caracterizada por altos valores de biomassa de protozoários e outros organismos menores, que não bactérias.

Em quase todos os meses a estação 8 apresentou as maiores contribuições, porém altos valores foram encontrados em alguns meses nas estações 1 e 7. As altas correlações encontradas entre os valores de ATP e biomassa bacteriana, principalmente na enseada de Ubatuba (estação 5 a 8) mostra o acoplamento entre as variações microbianas e bacterianas nas estações. Os altos valores de biomassa microbiana (excluindo bactérias) em estações como 5 e 6 podem estar sendo sustentados pelos altos valores de bactéria também encontrados nestas estações. Alguns estudos vêm demonstrando que protozoários podem utilizar aproximadamente $3 \%$ do total de biomassa bacteriana em sua base diária de alimentação (Starrink et al, 1994), sendo os principais consumidores de bactérias em certas áreas (Dietrich \& Arndt, 2000; Garstecki \& Wickham, 2001). Os baixos valores de biomassa bacteriana em estações como 1, 7 e 8 podem ter levado a valores muito baixos de protozoários permitindo maiores contribuições bacterianas na biomassa microbiana total. Hondeveld et al. (1994) encontrou correlação positiva entre a densidade de flagelados e bactérias, e concluiu que a população bacteriana pode limitar a densidade da população de flagelados a valores muito baixos. Maiores valores de meiofauna encontrados nestas estações podem ainda ter levado ao maior consumo de protozoários, diminuindo assim a biomassa destes organismos e permitindo maiores contribuições bacterianas. Alguns estudos observaram a utilização preferencial de protozoários como recurso para a meiofauna (Walter \& Moriarty, 1993; Dietrich \& Arndt, 2000).

Variações sazonais na contribuição bacteriana para a biomassa microbiana não foram significativas. Apenas a estação 7 apresentou um grande aumento na contribuição bacteriana no mês de junho, chegando a representar mais de $50 \%$ da biomassa. 


\subsection{Distribuição da comunidade bacteriana na coluna sedimentar.}

Os perfis verticais de densidade e biomassa bacteriana mostraram, de forma geral, uma maior concentração na camada superficial do sedimento em todas as épocas estudadas. Este padrão também foi encontrado por vários autores em diferentes sedimentos marinhos (Fabiano \& Danovaro, 1994; Relaxans et al., 1996; Parkes, et al., 2000; Eardly et al., 2001; Köster \& Meyer-Reil, 2001; Smith et al., 2002). Os maiores valores de densidade e biomassa bacteriana na camada superficial seguem a distribuição do material orgânico no sedimento.

Geralmente, os altos valores na camada superficial do sedimento e diminuição com a profundidade foram acompanhados por tendências similares nos valores de clorofilaa, mas não completamente pelos valores de MOT (Quintana, comunicação pessoal). Estes apresentaram maiores variações na coluna sedimentar. Muitos estudos também observaram perfis similares, relacionando os altos valores de MOT nas camadas mais profundas do sedimento ao transporte pela própria fauna (i.e. bioturbação), mantendo a matéria orgânica preservada nas camadas mais profundas do sedimento devido a baixas taxas de decomposição (Aller \& Yinst, 1980; Mather \& Parkes, 2000; Pfannkuche et al., 2000; Stoeck \& Kröncke, 2001).

A distribuição vertical de densidade e biomassa bacteriana na coluna sedimentar parece ser também influenciada pela granulometria local. Em sedimentos de grãos finos, a baixa permeabilidade do sedimento limita o metabolismo de bactérias aeróbicas e subaeróbicas à camada superficial. A alta permeabilidade de sedimentos arenosos permite maiores fluxos de água, levando compostos oxidantes dissolvidos e matéria orgânica particulada, o que suporta populações bacterianas mais abundantes em locais mais profundos da coluna sedimentar (Huettel \& Rusch, 2000; Rush et al. 2003). Algumas estações amostradas mostraram maiores valores de biomassa e densidade bacteriana em camadas mais profundas do sedimento. $\mathrm{Na}$ maioria das vezes, estes altos valores bacterianos acompanharam maiores valores de MOT ou clorofila-a (Quintana, comunicação pessoal). Desta forma, a distribuição da densidade e biomassa na coluna sedimentar da região estudada parece estar altamente correlacionada com a distribuição de matéria orgânica lábil. A maioria das estações que mostraram picos subsuperficiais apresentou alta porcentagem de areia. Pfannkuche et al. (2000) sugeriu que, em áreas de sedimentos 
contendo maiores porções arenosas, os processos de mistura do sedimento são altamente atuantes e são comuns picos bacterianos subsuperficiais, acompanhando picos de MOT e clorofila-a.

A atividade bacteriana, medida pela porcentagem de células em divisão, foi maior nas camadas mais profundas do sedimento (abaixo de $2 \mathrm{~cm}$ ) em várias estações de coleta, principalmente na enseada de Fortaleza (estações 1 a 4). Este local apresentou números elevados de indivíduos da macrofauna quando comparados à enseada de Ubatuba. Os picos subsuperficiais de atividade bacteriana encontrados podem estar relacionados com atividades da infauna (bioturbação), já que a macrofauna bêntica aumenta a atividade microbiana e a capacidade para decomposição da matéria orgânica no sedimento através dos seus efeitos no transporte de soluto e partículas (Kristensen \& Kostka, 2004). Organismos macrofaunais construtores de tubos ventilam ou irrigam seus tubos ativamente, promovendo assim o transporte de oxigênio e outros compostos oxidados para as camadas mais profundas do sedimento. Além disso, promovem a retirada de metabólitos, como amônia e sulfetos, aumentando a atividade bacteriana nas camadas mais profundas da coluna sedimentar (Kristensen, 2000). O aumento da decomposição da matéria orgânica na presença de certas espécies de macrofauna foi demonstrado por vários estudos experimentais (Kristensen \& Holmer, 2001; Kristensen \& Mikkelsen, 2003; MermillodBlondin et al., 2004).

Alguns organismos construtores de tubos parecem também "cultivar" bactérias no interior e nas paredes de seus tubos. Os animais promovem uma irrigação da água sobrejacente para dentro do seu tubo, trazendo consigo matéria orgânica particulada, a qual pode ficar embebida na parte interna das galerias. O acúmulo de matéria orgânica estimula o crescimento e atividade microbiana, e estas bactérias produzidas são ingeridas pelos organismos bênticos (Kogure \& Wada, 2005). Este comportamento da macrofauna poderia explicar as altas taxas de atividade bacteriana nas camadas mais profundas do sedimento, e ainda os baixos valores de densidade biomassa encontrados nestas profundidades.

Outro fato que tem sido atribuído ao aumento de atividade, mas não de densidade e biomassa em tubos de macrofauna, é a predação pela meiofauna de bactérias presentes nestes locais (Wetzel et al., 1995). Outra explicação possível seria que, enquanto o número médio de células não aumenta nas paredes das galerias, a atividade e crescimento de certos 
grupos metabólicos de bactérias podem ser estimulados (Kristensen \& Kostka, 2004). Além disso, tem sido observado um aumento da fração viável bacteriana em porções mais profundas da coluna sedimentar, na presença de fauna construtora de tubo, porém a contagem direta leva em conta tanto células viáveis como mortas levando a estas diferenças na atividade entre as profundidades do sedimento (Haglund et al., 2003).

Desta forma muitas poderiam ser as explicações para o padrão de grandes atividades nas camadas mais profundas da coluna sedimentar, no entanto parece ser certo que a presença de organismos da macrofauna influencia de forma positiva para este padrão. O conhecimento da fauna presente em cada estação é necessário, uma vez que a magnitude dos efeitos da bioturbação nos sedimentos irá depender dos grupos funcionais dos animais (definidos geralmente pelo tipo de alimentação, hábito de vida e mobilidade), abundância, peculiaridades taxonômicas e tamanho dos indivíduos (Kristensen, 2000).

\section{CONCLUSÕES}

- A área de estudo possui valores de densidade e biomassa bacteriana $\left(10^{8}-10^{9}\right.$ células e $10^{-5}-10^{-6} \mathrm{~g} \mathrm{C}$, respectivamente) característicos de regiões costeiras;

- Os padrões granulométricos associados à circulação das massas de água e a quantidade de matéria orgânica dirigem a dinâmica bacteriana bêntica nas enseadas de Ubatuba;

- A ressuspensão dos sedimentos associada à passagem de frentes frias promove o aumento nos valores de densidade e biomassa bacteriana durante o inverno;

- A comunidade bacteriana da região possui taxas de atividade, quando comparado a outras regiões costeiras.

- As bactérias bênticas representam uma porção pequena $(<1 \%)$ do carbono orgânico total na área de estudo. 


\section{CONSIDERAÇÕES FINAIS E PERSPECTIVAS FUTURAS}

Este estudo mostrou que a comunidade bacteriana depende de vários fatores, como granulometria e qualidade da matéria orgânica sedimentar, os quais aqui apresentados. Outros parâmetros ainda estão sendo analisados dentro do projeto DIAGEN, tais como dados referentes a biomarcadores lipídicos e biomassa e identificação dos metazoários. Desta forma, a obtenção dos dados podem dar maior suporte para que se possa responder as questões que ainda ficaram obscuras com os dados até o presente disponíveis.

O trabalho aqui apresentado mostra um estudo geral da distribuição da comunidade bacteriana presente nos sedimentos das enseadas de Ubatuba e Fortaleza. Como nenhum estudo preliminar a este foi feito na região, este estudo contribui de forma inédita para o estudo microbiano no Brasil. Os valores de densidade e biomassa bacteriana e as altas atividades medidas mostram a importância da comunidade bacteriana para os ciclos de nutrientes nos sedimentos da região. Porém, variações nas comunidades de bactérias encontradas necessitam de estudos com técnicas mais atuais, tanto em respeito à matéria orgânica presente no sedimento quanto da comunidade bacteriana que ali reside.

A porção da matéria orgânica realmente sendo utilizada pela comunidade bacteriana é importante para o entendimento das variações observadas na comunidade e na introdução de biomassa no ecossistema. Estudos mais detalhados da matéria orgânica, como o conteúdo protéico, carboidratos e lipídios têm sido extensivamente realizados, e diferenças na composição destes compostos parecem influenciar grandemente a comunidade bacteriana do sedimento (Fabiano \& Danovaro, 1994; Danovaro \& Fabiano, 1995; Relexans et al., 1996; Albertelli et al., 1999; Danovaro et al., 1999). Mais recentemente técnicas de biomarcadores lipídicos e estudos moleculares com isótopos de carbono estáveis tem sido aplicados para avaliar a matéria orgânica em ambientes naturais, bem como para como certos recursos são utilizados preferencialmente pelas comunidades bacterianas (Boscker et al., 2005; Daí \& Sun, 2006).

Adicionalmente, os padrões de atividade de enzimas extracelulares (AEE) parecem fornecer informações sobre a disponibilidade de matéria orgânica no sistema. Variações da AEE são geralmente tidas como um passo-chave na degradação e utilização de polímeros orgânicos pelas bactérias. Esta técnica tem sido extensivamente aplicada em estudos de 
resposta bacteriana à qualidade da matéria orgânica sedimentar (Boetius et al, 2000; Danovaro et al., 2002).

Quanto à comunidade bacteriana, evidências recentes têm mostrado que as bactérias apresentam espécies freqüentemente dominantes, tanto em termos de abundância relativa quanto em termos de contribuição para os processos do ecossistema. Desta forma, para predizer respostas da comunidade a mudanças ambientais é necessário determinar os padrões de diversidade bacteriana (Fuhrman et al., 2006). Técnicas utilizadas para análise da diversidade bacteriana têm sido baseadas em técnicas de PCR (Polymerase Chain Reaction) e em seqüências do 16S rRNA ou 16S rDNA (Acinas et al., 1999; Wobus et al., 2003; Kope et al., 2005), fornecendo informações qualitativas da comunidade bacteriana. Analises quantitativas da estrutura da comunidade parecem ser bem representadas por técnicas FISH (Fluorescence in situ Hybridization); Wobus et al., 2003). Outras técnicas, como o DGGE (Denaturing Gradient Gel Eletrophoresis), também têm sido utilizadas no estudo de comunidades microbianas (Muyzer, 1999; Franco et al., 2007). Ainda, análises mais sofisticadas que aplicam filogenias moleculares, microensaios de DNA, genômica funcional e atividades in situ vêm providenciando grandes quantidades de novidades e aumentando potencialmente o entendimento da estrutura e função dos ecossistemas microbianos, bem como as interações que ali ocorrem (DeLong, 2005).

Além disso, a atividade bacteriana também tem sido extensivamente estudada, e várias técnicas têm sido amplamente utilizadas para medir a real taxa de compostos assimilados e convertidos em biomassa bacteriana. Técnicas de incorporação de timidina e leucina (Kirschner \& Velimirov, 1999), de taxas de respiração bacteriana e de eficiência de crescimento bacteriano (Jimenz-Mercado, et al., 2007) fornecem informações adicionais sobre a estrutura da comunidade do sedimento e do fluxo de carbono através dos níveis tróficos. A interação e partição da biomassa entre os diversos níveis tróficos (micro, meio e macrofauna) também tem sido foco de diversos estudos no ambiente costeiro.

Desta forma, ainda há muito a ser feito na região estudada para se conhecer a comunidade microbiana ali presente e os processos diagenéticos atuando no sedimento, em especial através da utilização das modernas técnicas citadas acima. 


\section{REFERÊNCIAS BIBLIOGRÁFICAS}

Acinas, S.G.; Antón, J. \& Rodríguez-Valera, F. 1999. Diversity of free-living and attached bacteria in offshore western mediterranean waters as depicted by analysis of genes encoding 16S rRNA. Appl. Environm. Microb. 65(2):514-522.

Aidair, E.; Gaeta, S.A.; Gianesella-Galvão, S.M.F.; Kutner, M.B.B. \& Teixeira, C. 1993. Ecossistema costeiro subtropical: nutrientes dissolvidos, fitoplâncton e clirofila- $a$ e suas relações com as condições oceanográficas na região de Ubatuba, SP. Pub. Esp. Inst. Oceanogr., São Paulo, 10: 9-43.

Albertelli, G.; Covazzi-Harriague, A.; Danovaro, R.; Fabiano, M.; Fraschetti, S. \& Pusceddu, A. 1999. Differential responses of bacteria, meiofauna and macrofauna in a shelf area (LIgurian Sea, NW Mediterranean): role of food availability. J. Sea Res. 42: 11-26.

Aller, R. C. 1994. Bioturbation and remineralization of sedimentary organic matter: effects of redox oscillation. Chem. Geol. 114: 331-345.

Aller, R.C. \& Aller, J.Y. 1998. The effect of biogenic irrigation intensity and solute exchange on diagenetic reaction rates in marine sediments. J. Mar. Res. 56: 905938.

Aller, R.C. \& Yinsgst, J.T. 1980. Relationships between microbial distributions and the anaerobic decomposition of organic matter in surface sediments of Long Island Sound, USA. Mar. Biol. 56: 29-42.

Alongi, D.M. 1985. Effect of physical disturbance on population dynamics and trophic interation among microbes and meiofauna. J. Mar. Res. 43: 351-364.

Alongi, D.M. 1994. The role of bacteria in nutrient recycling in tropical mangrove and other coastal benthic ecosystems. Hydrobiol. 285: 19-32.

Arndt, H 1991. On the importance of planktonic protozoans in the eutrophication process of the Baltic Sea. Int. Re.v ges. Hydrobiol. 76: 387-396.

Boetius, A.; Springer, B.\& Petry, C. 2000. Microbial activity and particulate matter in the benthic nepheloid layer (BNL) of the deep Arabian Sea. Deep-Sea Res. II 47: 2687 2706. 
Boon, A.R.; Duineveld, G.C.A. \& Kok, A. 1999. Benthic organic matter supply and metabolism at depositional and non-depositional areas in the North Sea. Estuar. Coast. Shelf Sci. 49: 747-761.

Børsheim, K.Y.; Bratbak, G. \& Heldal, M. 1990. Enumeration and biomass estimation of planktonic bacteria and viruses by transmission electron microscopy. Appl. Environm. Microbiol. 56(2): 352-356.

Boschker, H.T.S.; Kromkamp, J. \& Middelburg, J.J. 2005. Biomarker and carbon isotopic constraints on bacterial and algal community structure and functioning in the highly polluted Scheldt estuary. Limnol. Oceanogr. 50: 70-80.

Bouillon, S. \& Boschker, H.T.S. 2006. Bacterial carbon sources in coastal sediments: a cross-system analysis based on stable isotope data of biomarkers. Biogeosciences. $\mathbf{3}$ : 175-185.

Bouvy, M. 1987. Contribution of the bacterial and microphytobenthic microflora in the energetic demand to the meiobenthos in an intertidal muddy sediment (Kerguelen Archipelago). Mar. Ecol. 9(2): 109-122.

Burone, L.; Muniz, P.; Pires-Vanin, A.M.S. \& Rodrigues. M. 2003. Spatial distribution of organic matter in the surface sediments of Ubatuba Bay (Southeastern- Brazil). Ann. Brazil. Acad. Sci. 75(1): 77-90.

Braga, E.S. \& Muller, T.J. 1998. Observation of regeneration of nitrate, phosphate and silicate during upwelling off Ubatuba, Brazil, $23^{\circ}$ S. Cont. Shelf Res. 18: 915-922.

Bratbak, G. 1985. Bacerial Biovolume and Biomass Estimations. Appl. Environm. Microbiol. 49(6): 1488-1493.

Bühring, S. I.; Elvert, M. \& Witte, U. 2005. The microbial community structure of different permeable sandy sediments characterized by the investigation of bacterial fatty acids and fluorescence in situ hybridization. Environm. Microbiol. 7(2): 281-293

Byers, S.C.; Mills, E.L. \& Stewart, P.L. 1978. A comparison of methods to determining organic carbon in marine sediments, with suggestion for a standard method. Hydrobiologia 58: 43-37.

Cammen. L.M. 1991. Annual bacterial production in relation to benthic microalgal production and sediment oxygen uptake in an intertidal sandflat and an intertidal mudflat. Mar. Ecol. Prog. Ser. 71: 13-25. 
Camuel, E.A. \& Martens, C.S. 1993. Seasonal variation in the sources and accumulation of organic matter associated whith recently deposited sediments. Org. Geochem. 20: 563-577.

Camuel, E.A. \& Martens, C.S. 1996. Reactivity of recently deposited organic matter: degradation of lipid compounds near the sediment-water interface. Geochim. Cosmochim. Acta. 60(10): 1793-1806.

Cassel, E.A. 1965. Rapid Graphical Method for Estimating the Precision of Direct Counting data. Appl. Environm. Microbiol. 13(3): 293-296.

Castro-Filho, B.M.; Miranda, L.B. \& Miyao, S.Y. 1987. Condições hidrográficas na plataforma continental ao largo de Ubatuba: variações sazonais e em média escala. Bolm. Inst. Oceanogr., São Paulo. 35 (2): 135-151.

Cowan, J.L.W.; Pennock, J.R. \& Boynton, W.R. 1996. Seasonal and interannual patterns of sediment-water nutrient and oxygen fluxes in Mobili Bay, Alabama (USA): regulating factors an ecological significance. Mar. Ecol. Prog. Ser. 144: 229-245.

Craven, D.B. \& Jahnke, R.A. 1992. Microbial utilization and turnover of organic carbon in Santa Monica Basin sediments. Prog. Oceanog. 30: 313-333.

Curvelo, R.R. 2003. Variação da estrutura e distribuição da meiofauna na Enseada de Picinguaba - Ubatuba, São Paulo. Tese de Doutorado. Universidade de São Paulo, Instituto Oceanográfico. 145p.

Dai, J. \& Sun M.-Y. 2007. Organic matter sources and their use by bacteria in the sediments of the Altamaha estuary during high and low discharge periods. Org. Geochim. 38: 1-15.

Dale, N.G. 1974. Bacteria in intertidal sediments: Factors relater to their distribution. Limnol. Oceanogr. 19(3): 509-517.

Danovaro, R. 1996. Detritus-bacteria-meiofauna interactions in a seagrass bed (Posidonia oceanica) of the NW Mediterranean. Mar. Biol. 127: 1-13.

Danovaro, R. \& Fabiano, M. 1995. Seasonal and inter-annual variation of bacteria in a seagrass bed of the Mediterranean Sea: relationship with labile organic compounds and other environmental factors. Aquat. Microb. Ecol. 9: 17-26. 
Danovaro, R.; Fabiano, M. \& Della Croce, N. 1993. Labile organic matter and microbial biomasses in deep-sea sediments (Eastern Mediterranean Sea). Deep-Sea Res. I 40: 953-965.

Danovaro, R.; Fabiano, M. \& Boyer, M. 1994. Sesonal changes of benthic bactéria in seagrass bed (Posidonia oceanica) of the Ligurian Sea in relation to origin, composition and fate of the sediment organic matter. Mar. Biol. 119: 489-500.

Danovaro, R.; Marrale, D.; Della Croce, N.; Dell'Anno, A. \& Fabiano, M. 1998. Heterotrophic, nanoflagellates, bacteria, and labile organic compounds in continental shelf and deep-sea sediments of the eastern Mediterranean. Microb. Ecol. 35: 244-255

Danovaro, R.; Marrale, D.; Della Croce, N.; Parodi, P. \& Fabiano, M. 1999. Biochemical composition of sedimentary organic matter and bacterial distribution in the Aegean Sea: trophic state and pelagic-benthic coupling. J. Sea Res. 42: 117-129.

Danovaro, R.; Marrale, D.; Dell'Anno, A.; Della Croce, N.; Tselepides, A. \& Fabiano, M. 2000. Bacterial response to seasonal changes in labile organic matter composition on the continental shelf and bathyal sediments of the Cretan Sea. Prog. Oceanogr. 46: $345-366$.

Danovaro, R.; Manini, E. \& Fabiano, M. 2002. Exoenzimatic activity and organic matter composition in sediments of the Northern Adriatic Sea: response to a river plume. Microb. Ecol. 44: 235-251.

De Flaun, M.F. \& Mayer, L.M. 1983. Relationships between bacteria and grain surface in intertidal sediments. Limnol. Oceanogr. 28: 873-881.

Delille, D. \& Bouvy, M. 1989. Bacterial response to natual organic inputs in a marine subAntartic area. Hydrobiologia. 182: 225-238.

Deming, J.W. \& Baross, J.A. 1993. The early diagenesis of organic matter: bacterial activity. In M.H. Engel, \& S. Macko, Organic geochemistry: principles and applications. Topics in geobiology New York: Plenum Press. pp.119-144.

DeLong, E.F. 2005. Microbial community genomics in the ocean. Nature Rev. 3: 459-469.

Dietrich, D. \& Arndt, H. 2000. Biomass portioning of benthic microbes in Baltic inlet: relationships between bacteria, algae, heterotrophic flagellates and ciliates. Mar. Biol. 136: 309-322. 
Duarte, C.M.; Middelburg, J.J. \& Caraco, N. 2004. Major role of marine vegetation on the oceanic carbon cycle. Biogeosc. 2:1-8.

Eardly, D.F.; Carton, M.W.; Gallagher, J.M. \& Patching, J.W. 2001. Bacterial abundance and ativity in deep-sea sediments from the eastern North Atlantic. Prog. Oceanogr. 50: $245-259$.

Eiler, A.; Langenheder, S.; Bertilsson, S. \& Tranvik. 2003. Heterothophic bacterial growth efficiency and community structure at different natural organic carbon concentrations. Appl. Environ. Microb. 69(7): 3701-3709.

Epstein, S.S. 1997. Microbial Food Webs in Marine Sediments. II. Seasonal Changes in Trophic Interactions in a Sandy Tidal Flat Community. Microb. Ecol. 34:199-209.

Epstein. S.S. \& Shiaris, M.P. 1992. Rates of microbenthic and meiobenthic bacteriovory in a temperate muddy tidal flat community. Appl. Environ. Microb. 58(8): 2426-2431.

Fabiano, M. \& Danovaro, R. 1994. Composition of organic matter in sediments facing a river estuary (Tyrrhenian Sea): relationship with bacteria and microphytobenthic biomass. Hydrobiologia. 277: 71-84.

Fabiano, M. \& Danovaro, R. 1998. Enzymatic Activity, bacterial distribution, and organic matter composition in sediments of Ross Sea (Antarctica). Appl. Environ. Microb. 64(10): 3838-3845.

Fabiano,M.; Danovaro, R. \& Fraschettit, S. 1995. A three-year time series of elemental and biochemical composition of organic matter in subtidal sandy sediments of the Ligurian Sea (northwestern Mediterranean). Cont. Sh. Res. 15 (11/12): 1453-1469.

Fiederlmondo, C. \& Pusceddu, A. 2004. Short-term response of benthic bacteria and nanoflagellates to sediment resuspension: an experimental study. Chem. Ecol. 20(2): 107-121.

Findlay, R.H.; Trexler, M.B.; Guckerte, J.B. \& White, D.C. 1990. Laboratory study of disturbance in marine sediments: response of a microbial community. Mar. Ecol. Prog. Ser. 62: 121-133.

Franco, M.A.; De Mesel, I.; Diallo, M.D.; Van der Gucht, K.; Van Gansbeke, D.; van Rijswijk P.; Costa, M.J.; Vincx, M. \& Vanaverbeke, J. 2007. Effect of phytoplankton bloom deposition on benthic bacterial communities in two contrasting sediments in the southern North Sea. Aquat. Microb. Ecol. 48: 241-254. 
Folk, R.L. \& Ward, W.C. 1957. Brazos River bar: a study of the significance of grain size parameters. J. Sedim. Petrology. 27: 3-26.

Fuhrman, J.A.; Hewson, I.; Schwalbach, M.S.; Steele, J.A.; Brown, M.V. \& Naeem, S. 2006. Annually reoccurring bacterial communities are predictable from ocean conditions. PNAS. 103(35): 13104-13109.

Gaeta, S.A.; Abe, D.S.; Metlzler, P.M. \& Teixeira, C. 1995. Photosynthetic parameters of coastal marine phytoplankton from the Ubatuba region, Brazil. Pub. Esp. Inst. Oceanogr., São Paulo, 11: 163-169.

Gaeta, S.A.; Ribeiro, S.M.S.; Metzler, P.M.; Francos, M.S. \& Abe, D.S. 1999. Environmental forcing on phytoplankton biomass and primary productivity of the coastal ecosystem in Ubatuba region, southern Brazil. Rev. Bras. Oceanogr. 47: 1127.

Garstecki, T. \& Wickham, S.A. 2001. Effects of resuspension and mixing on population dynamics and trophic interactions in a model benthic microbial food web. Aquat. Microb. Ecol. 25: 281-292.

Graf, G. 1989. Benthic-pelagic coupling in a deep-sea benthic community. Nature. 341: 437-439.

Graf, G.; Shulz, T.; Peinert, R. \& Meyer-Reil, L.A. 1983. Benthos response to sedimentation during autumn to spring at shallow water station in the western Kiel bight. I. Analysis of processes on the community level. Mar. Biol. 77: 235-246.

Haglund, A.-L; Lantz, P.; Törnblom, E. \& Tranvik, L. 2003. Depth distribution of active bacteria and bacterial activity in lake sediment. Microb. Ecol. 46: 31-38.

Hamels, I.; Muylaert, K.; Casteleyn, G. \& Vyverman, W. 2001. Uncoupling of bacterial production and flagellate grazing in aquatic sediments: a case study from an intertidal flat. Aquat. Microb. Ecol. 25: 31-42.

Hangström, A.; Larsson, U.; Hörstedt, P. \& Normark, S. 1979. Frequency of dividing cells, a new approach to the determination of bacterial growth rates in aquatic environments. Appl. Environm. Microb. 37(5): 805-812.

Hedges, J.I.; Keil, R.G. \& Benner, R. 1997. What happens to terrestrial organic matter in the ocean? Org. Geochem. 27 (5-6): 195-212. 
Henrichs, S.M. 1992. Early diagenesis of organic matter in marine sediments: progress and perplexity. Mar. Chem. 39: 119-149.

Hollnagel, H.C. 1994. Bactérias e outros microorganismos dos sedimentos do infralitoral

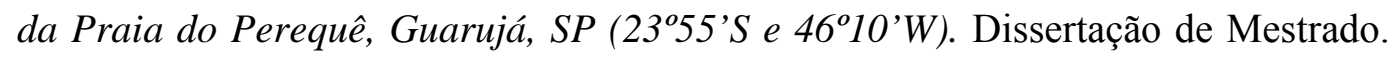
Universidade de São Paulo, Instituto Oceanográfico. 114p.

Hondeveld, B.J.M.; Nieuwland, G.; van Duyl, F.C. \& Bak, R.P.M. 1994. Temporal and spatial variations in heterotrophic nanofagelates abundance in North Sea sediments. Mar. Ecol. Prog. Ser. 109: 235-243.

Horrigan, S. G.; Hangström, A.; Koike, I. \& Azam, F. 1988. Inorganic nitrogen utilization by assemblages of marine bacteria in seawater culture. Mar. Ecol. Prog. Ser. 50: 147-150.

Huettel, M. \& Gust, G. 1992. Impact of bioroughness on interfacial solute exchange in permeable sediments. Mar. Ecol. Prog. Ser. 89: 253-267.

Huettel, M. \& Rusch, A. 2000. Transport and degradation of phytoplankton in permeable sediment. Limnol. Oceanogr. 45: 534-549.

Jiménez-Mercado, A.; Cajal-Medrano, R. \& Maske, H. 2007. Marine Heterotrophic Bacteria in Continuous Culture, the Bacterial Carbon Growth Efficiency, and Mineralization at Excess Substrate and Different Temperatures. Microb. Ecol. 54: 56-64.

Jørgensen, B.B. 2000. Bacteria and Marine Biogeochemistry. In: Schulz, H.D. \& Zabel, M. (eds.): Mar. Geochem., Springer, p.p. 173-207.

Karl, D.M. 1980. Cellular nucleotide measurements and applications in microbial ecology. Microbiological Review 44: 739-796.

Karl, D.M. \& Novitsky, J.A. 1988. Dynamics of microbial growth in surface layers of a coastal marine sediment ecosystem. Mar. Ecol. Prog. Ser. 50: 169-176.

Kemp, P.F. 1990. The fate of bacterial production. Rev. Aquat. Sci. 2:109-124.

Kirschner, A.K.T. \& Velimirov, B. 1999. Benthic bacterial secondary production measured via simultaneous ${ }^{3} \mathrm{H}$-thymidine and ${ }^{14} \mathrm{C}$-leucine incorporation, and its implication for the carbon cycle of a shallow macrophyte-dominated backwater system. Limnol. Oceanogr. 44(8): 1871-1881. 
Kogure, K. \& Wada, M. 2005. Impacts of macrobenthic bioturbation in marine sediment on bacterial metabolic activity. Microbes Environm. 20(4):191-199.

Köpke, B.; Wilms, R.; Engelen, B.; Cypionka, H. \& Sass, H. 2005. Microbial diversity in coastal subsurface sediments: a cultivation approach using various electron acceptors and substrate gradients. Appl. Environm. Microb. 71(12): 7819-7830

Köster, M. \& Meyer-Reil, L.A. 2001. Characterization of carbon and microbial biomass pool in shallow water costal sediments of the southern Baltic Sea (Nordrügensce Bodden). Mar. Ecol. Prog. Ser. 214: 25-41.

Köster, M.; Dahlke, S. \& Meyer-Reil, L.A. 1997. Microbiological studies along a gradient of eutrophication in a shallow coastal inlet in the southern Baltic Sea (Nordrügensche Bodden). Mar. Ecol. Prog. Ser. 152: 27-39.

Köster, M.; Dahlke, S. \& Meyer-Reil, L.A. 2005. Microbial colonization and activity in relation toorganic carbon in sediments of hypertrophic coastal waters (Nordrügensche Bodden, Southern Baltic Sea). Aquat. Microb. Ecol. 39: 69-83.

Kristensen, E. 2000. Organic matter diagenesis at the oxic/anoxic interface in coastal merine sediments, with emphasis on the role of burrowing animals. Hydrobiologia 426:1-24.

Kristensen, E.; Ahmed, S.I.; Devol, A.H. 1995. Aerobic and anaerobic decomposition of organic matter in marine sediment: which is fastest? Limnol. Oceanog. 40(8): 14301437.

Kristensen, E. \& Holmer, M. 2001. Decomposition of plant materials in marine sediment exposed to different electron acceptors $\left(\mathrm{O}_{2}, \mathrm{NO}_{3}{ }^{-}\right.$, and $\left.\mathrm{SO}_{4}^{-2}\right)$, with emphasis on substrate origin, degradation kinetics, and role of bioturbation. Geochim. Cosmoch. Acta 65: 419-433.

Kristensen, E. \& Mikkelsen, O.L. 2003. Impact of the burrow-dwelling polychaete Nereis diversicolor on the degradation of fresh and aged macroalgal detritus in a coastal marine sediment. Mar. Ecol. Prog. Ser. 265:141-153.

Kristensen, E. \& Kostka, J.E. 2005. Macrofaunal burrows and irrigation in marine sediment: microbiological and biogeochemical interactions. In: Interactions between Macro- and Microorganisms in Marine Sediments, E. Kristensen, J.E. Kostka, R. Haese (edit's), American Geophysical Union, Washington, DC. 390 pp. 
Kröncke, I.; Stoeck, T.; Wiking, G. \& Palojärvi, A. 2004. Relationship between structural and functional aspcts of microbial and macrofaunal communities in different areas of the North Sea. Mar. Ecol. Prog. Ser. 282: 13-31.

Lavigne, C.; Juniper, S.K. \& Silverberg, N. 1997. Spatio-temporal variability in benthic microbial activity and particle flux in the Laurentian Trough. Deep-sea Res. I 44(11): 1793-1813.

Mahiques, M.M. 1995. Dinâmica sedimentr atual nas enseada da região de Ubatuba, Estado de São Paulo. Bolm. Inst. Oceanogr. 43(2): 111-122.

Mahiques, M.M.; Tessler, M.G. \& Furtado, V.V. 1998. Characterization of energy gradient in enclosed Bays of Ubatuba region, South-eastern Brazil. Estuar. Coast. Shelf Sci. 47: 431-446.

Mather, I.D. \& Parkes, R.J. 2000. Bacterial profiles in sediments of the eastern flank of the Juan de Fuca ridge, sites 1026 and 10271. In: Fisher, A.; Davis, E.E. \& Escutia, C. (Eds.) Proceedings of the Ocean Drilling Program, Scientific Results. 168(13): 162165 .

Mayer, L.M. 1994. Relationships between mineral surfaces and organic carbon concentrations in soils and sediments. Chem. Geol. 114:347-363.

Mermillod-Blondin, F.; Rosenberg, R.; François-Carcaillet, F.; Norling, K. \& Mauclaire, L. 2004. Influence of bioturbation by three benthic infaunal species on microbial communities and bigeochemical processes in marine sediment. Aquat. Microb. Ecol. 36: $271-284$

Mermillod-Blondin, F.; François-Carcailletb, F. \& Rosenberg, R. 2005. Biodiversity of benthic invertebrates and organic matter processing in shallow marine sediments: an experimental study. J. Experim. Mar. Biol. Ecol. 315: 187-209.

Mesquita, H.S.L. 1993. Densidade e distribuição do bacterioplâncton nas águas de Ubatuba $\left(23^{\circ} \mathrm{S} 45^{\circ} \mathrm{W}\right)$, Estado de São Paulo. Publ. Esp. Inst. Oceanogr., São Paulo 10: 45-63.

Mesquita, H.S.L. \& Peres, C.A. 1985. Numerical contribution of phytoplanctonic cells, heterotrophic particles and bacteria to size fractionated POC in the Cananéia estuary $\left(25^{\circ} \mathrm{S}-48^{\circ} \mathrm{W}\right)$, Brazil. Bol. Inst. Oceanogr., São Paulo. 33 (1): 69-78. 
Meyer-Reil, L.A. 1983. Benthic response to sedimentation events during autumn to spring at shallow water station in the Western Kiel Bight. II. Analysis of benthic bacterial populations. Mar. Biol. 77: 247-256.

Meyer-Reil, L.A.; Dawson, R.; Liebezeit, G. \& Tiedge, H. 1978. Fluctuations and interactions of bacterial activity in sandy beach sediments and overlying waters. Mar. Biol. 48: 161-171.

Meyer-Reil, L.-A..; Bolter, M.; Dawson, R.; Liebezeit, G.; Szwerinski, H. \& Wolter, K. 1980. Interrelationships between microbiological and chemical parameters of sandy beach sediments, a summer aspect. Appl. Environm. Microbiol. 39(4): 797-802.

Meyer-Reil, L.A. \& Faubel, A. 1980. Uptake of organic matter by meiofaunal organisms and the interrelationship with bacteria. Mar. Ecol. Prog. Ser. 3: 251-256.

Meyer-Reil. L.A. \& Graf, G. 1986. Seasonal development of bacterial communities in a coastal marine sediment as related to input of organic material. IFREMER, Actes de Coloques, 3: 55-59.

Middelburg, J. J.; Nieuwenhuize, J.; Lubberts, R. K. \& van de Plassche, O. 1997. Organic carbon isotope systematics of coastal marshes. Estuar. Coast. Shelf Sci. 45: 681687.

Montagna, P.A. 1982. Sampling design and enumeration statistics for bacteria extracted from marine sediments. Appl. Environm. Microbiol. 46: 6, 1366-1372.

Montagna, P.A. 1984. In situ measurements of meiobenthic grazing rates on sediment bacteria and edaphic diatoms. Mar. Ecol. Prog. Ser. 18: 119-130

Muniz, P.M.; Sumida, P.Y.G. \& Pires-Vanin, A.M.S. 2000. Trophic structure of polychaetes in two bays of the southeastern Brazilian coast (Mar Virado and Fortaleza, Ubatuba, São Paulo). Oebalia. 24: 39-53.

Muniz, P.; Pires-Vanin, A.M.S.; Martins, C.C.; Montone, R.C. \& Bícego, M.C. 2006. Trace metals and organic compounds in the benthic environment of a subtropical embayment (Ubatuba Bay, Brazil). Mar. Pollut. Bull. 52: 1098-1105.

Muyzer, G. 1999. DGGE/TGGE: a method for identifying genes from natural ecosystems. Curr. Opin. Microbiol. 2: 317-322.

Nealson, K.H. 1997. Sediment bacteria: who's there, what are they doing, and what's new? Annu. Rev. Earth Planet. Sci. 25: 403-434. 
Novitsky, J.A. \& Karl, D.M. 1986. Characterization of microbial activity in the surface layers of a coastal sub-tropical sediment. Mar. Ecol. Prog. Ser. 28: 49-55.

Papaspyrou, S.; Thessalou-Legaki, M. \& Kristensen, E. 2004. Impact of Pestarella tyrrena on benthic metabolism in sediment microcosms enriched with seagrass and macroalgal detritus. Mar. Ecol. Prog. Ser. 281: 165-179.

Parkes, R.J.; Cragg, B.A. \& Wellsbury, P. 2000. Recent studies on bacterial populations and processes in subseafloor sediments: A review. Hydrogeol. J. 8: 11-28.

Pelegri, S.P.; Dolan, J. \& Rassoulzadegan, F. 1999. Use of high temperature catalytic oxidation (HTCO) to measure carbon content of microorganisms. Aquat. Microb. Ecol. 16: 273-280.

Pfannkuche, O. 1993. Benthic response to the sedimentation of particulate organic matter at the BIOTRANS station, $47^{\circ} \mathrm{N}-20^{\circ} \mathrm{W}$. Deep-Sea Res. II 40:135-150.

Pfannkuche, O. \& Soltwedel, T. 1998. Small benthic size classes along the N.W. European Continental Margin: spatial and temporal variability in activity and biomassa. Prog. Oceanogr. 42: 189-207.

Pfannkuche, O.; Sommer, S. \& Kähler, A. 2000. Coupling between phytodetritus deposition and the small-sized benthic biota in the dep Arabian Sea: analyses of biogenic sediment compounds. Deep-Sea Res. II 47: 2805-2833.

Pires-Vanin, A.M.S. \& Matsuura, Y. 1993. Estrutura e função do ecossistema de plataforma continental da região de Ubatuba, Estado de São Paulo: uma introdução. Publ. Esp. Inst. Oceanogr., São Paulo, 10: 1-8.

Quintana, C.O. 2004. Impactos da bioturbação na estrutura e distribuição vertical na infauna no sublitoral raso da Ilha Anchieta e Enseada do Flamengo (Ubatuba, SP). Dissertação de Mestrado. Universidade de São Paulo, Instituto Oceanográfico. $172 p$.

Raghukumar, C.; Bharathi, P.A.; Ansari, Z.A.; Nair, S.; Ingole, B.; Sheelu,G.; Mohandass,C.; Nath, B.N. \& Rodrigues, N. 2001. Bacterial standing stock, meiofauna and sediment-nutrient characteristics: indicators of benthic disturbance in the Central Indian Basin. Dee-Sea Res. II 48: 3381-3399. 
Releaxans, J.-C.; Deming, J.; Dinet, A.; Gaillard, J.-F. \& Sibuet, M. 1996. Sedimentary organic matter and micro- meiobenthos with relation to thophic conditions in the tropical northeast Atlantic. Deep-Sea Res. I 43 (8): 1343-1368.

Rocha, G. R. A.; Rossiwongtschowski, C. L D. B.; Pires-Vanin, A. M. S. \& Jarreteichmann, A. 2003. Seasonal budgets of organic matter in the Ubatuba shelf system, south-eastern Brazil. I. Planktonic and benthic components. Oceanol. Acta. 26(5/6): 487-495.

Rusch, A.; Huettel, M. \& Forsterb, S. 2000. Particulate organic matter in permeable marine sands-dynamics in time and depth. Est. Coast. Shelf Sci. 51: 399-414.

Rusch, A.; Huettel, M.; Reimers, C.E.; Taghon, G.L. \& Fuller, C.M. 2003. Activity and distribution of bacterial populations in Middle Atlantic Bight shelf sands. Microb. Ecol. 44: 89-100.

Sassi, R. \& Kutner, M. B. 1982.Variação Sazonal do Fitoplâncton da Região do Saco da

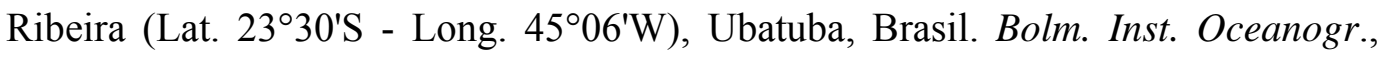
São Paulo. 31: 29-42.

Schmidt, J.L.; Deming, J.W.; Jumars, P.A. \& Keil, R.G. 1998. Constancy of bacterial abundance in surficial marine sediments. Limnol. Oceanogr. 43(5): 976-982.

Shepard, F.P. 1954. Nomenclature based on sand-silt-clay ratios. J. Sedim. Petrology 24: 151-158.

Sherr, E.B. \& Sherr, B.F. 1994. Bacterivory and herbivory: key roles of phagotrophic protists in pelagic food webs. Microb. Ecol. 28: 223-235.

Shiah, F.-K.; Liu, K.-K.; Kao, S.-J. \& Gong, G.-C. 2000. The coupling of bacterial production and hydrography in the southern East China Sea: spatial patterns in spring and fall. Cont. Shelf Res. 20: 459-477.

Smith, Jr. K.L.; Baldwin, R.J.; Karl, D.M. \& Boetius, A. 2002. Benthic community responses to pulses in pelagic food supply: North Pacific Subtropical Gyre. Deepsea Res. I 49: 971-990.

Soltwedel, T. 1997. Temporal variabilities in benthic activity and biomass on the western European continental margin. Oceanol. Act. 20(6): 871-879. 
Starink, M.; Krylova, I.N.; Bar-Gilissen, M.-J.; Bak, R. P. M. \& Cappenberg, T.E.1994. Rates of benthic protozoan grazing on free and attached sediment bacteria measured with fluorescently stained sediment. Appl. Environm. Microbiol. 60(7): 2259-2264.

Stoeck, T. \& Kröncke, T. 2001. Influence of particle mixing on vertical profiles of chlorophyll a and bacterial biomass in sediments of the German Bight, Oyster Ground and Dogger Bank (North Sea). Est. Coast. Shelf Sci. 52(6): 783-795.

Suess, E. 1976. Nutrients near the depositional interface. In: McCave, N. (ed.) The benthic boundary layer. Plenum Press, New York, p. 57-79.

Suguio, K. 1973. Introdução à sedimentologia. Ed. Edgard Blücher, São Paulo. 317 p.

Sumida, P.Y.G. \& Pires-Vanin, A.M.S. 1997. Benthic associations of the shelf break and upper slope off Ubatuba-SP, South-eastern, Brazil. Estuar. Coast. Shel. Sci. 44 (6): 779-784.

Sumida, P.Y.G.; Yoshinaga, M.Y.; Ciotti, A.M. \& Gaeta, S.A. 2005. Benthic response to upwelling events off the SE Brazilian coast. Mar. Ecol. Prog. Ser. 291: 35-42.

Sun, M.; Aller, R.C. \& Lee, C. 1991. Early diagenesis of chlorophyll-a in Long Island Sound sediments: A measure of carbon flux and particle reworking. J. Mar. Res. 49: $379-401$

Törnblom, E. \& Boström, B. 1995. Benthic microbial response to a sedimentation event at low temperature in sediments of a euthophic lake. Mar. Fresh. Res. 46: 33-43.

van Duyl, F.C. \& Kop, A.J. 1994. Bacterial production in North Sea sediments: clue to seasonal and spatial variations. Mar. Biol. 120: 323-337.

Vezzulli, L. \& Fabiano, M. 2006. Sediment biochemical and microbial variables for the evaluation of trophic status along the Italian and Albanian continental shelves. $J$. Mar. Biol. Assoc. UK. 86: 27-37.

Wakeham, S. \& Canuel, E. 2006. Degradation and preservation of organic matter in arine sediments. In: Volkman, J.K. (ed.) Marine organic matter: biomarkers, isotopes and DNA. Springer, pp. 295-322.

Watanabe, K. 1980. Distribution of aerobic, heterotrophic bacteria in Cananéia Estuary, Brazil. Acta Veterinaria (Beograd), 30 (5-6): 253-275.

Walters, K. \& Moriarty, D.J.W. 1993. The effects of complex trophic interactions on a marine microbenthic community. Ecology. 74: 1475-1489. 
Weise, W. \& Rheinheimer, G. 1978. Scaning electron microscopy and epifluorescence investigation of bacterial colonization of marine sand sediments. Microb. Ecol. 4: 175-188.

Wetzel, M.A.; Jensen, P. \& Giere, O. 1995. Oxygen/sulfide regime and nematode fauna associated with Arenicola marina burrows: New insights in the thiobios case. Mar. Biol. 124: 301-312.

Witte, U.; Aberle, N.; Sand, M. \& Wenzhöfer, F. 2003. Rapid response of a deep-sea benthic community to POM enrichment: an in situ experimental study. Mar. Ecol. Prog. Ser. 251: 27-36.

Wobus, A.; Bleul, C.; Maassen, S.; Scheerer, C.; Schuppler, M.; Jacobs, E. \& Röske, I. Microbial diversity and functional characterization of sediments from reservoirs of different trophic state. Microb. Ecol. 46: 331-347.

Yoshinaga, M.Y.; Quintana, C.O. \& Sumida P.Y.G. 2006. Sedimentary chlorophyll-a and microbial biomass as indicators of benthic processes in costal and shelf areas of the SE Brazilian coast (Ubatuba, SP). J. Coastal Res., SI 39: 1098-1101.

Yoshinaga, M.Y. 2006. Origem e composição da matéria orgânica e a dinâmica da comunidade microbiana em sedimentos superficiais de ecossistemas marinhos da costa sudeste do Brasil. Tese de Doutorado. Universidade de São Paulo, Instituto Oceanográfico. $133 \mathrm{p}$.

Zar, J.H. 1996. Bioestatistical analysis. $3^{\mathrm{a}}$ ed., Englewood Cliffis, Prentice-Hall, 661 p.

Zimmermann, R.; Iturriaga, R. \& Becker-Birck, J. 1978. Silmultaneous determination of the total number of aquatic bacteria and number thereof involved in respiration. Appl. Environm. Microb. 36 (6): 926-935. 